\title{
Regulatory Arbitrage, EXTRATERRITORIAL JURISDICTION, AND DODD-Frank: THE IMPLICATIONS OF US GLOBAL OTC Derivative Regulation
}

\author{
Christian Johnson*
}

\author{
INTRODUCTION
}

A review of the Dodd-Frank Wall Street Reform and Consumer Protection Act ("Dodd-Frank") and the multitude of Commodity Futures Trading Commission ("CFTC") and Securities and Exchange Commission ("SEC") rulemaking projects suggests that the United States has entered into a "race to the top" of over-the-counter ("OTC") derivative regulation. Pressing forward, Congress and the CFTC appear to be at least a year ahead of enacting OTC derivative reforms in contrast with other foreign competing jurisdictions. In addition, many of the statutes and rules adopted by the United States go well beyond the relatively modest commitments that competing jurisdictions have agreed to meet with respect to reforming their own OTC derivative markets. The US race to regulate OTC derivatives creates a legal environment ripe for regulatory arbitrage and the isolation of US OTC derivative markets, leaving the United States still vulnerable to systemic trading losses suffered in less or non-regulated jurisdictions.

US policymakers and regulators believe that losses stemming from unregulated OTC derivative trading could result in systemically significant financial failures in the United States, potentially triggering the next financial crisis. To prevent these systemic failures, the CFTC is aggressively promulgating rules and regulations to implement the Dodd-Frank OTC derivative reforms that will minimize the risk of future losses. The United States is determined not only to regulate the swap trading activity between US persons, but also the global swap trading activity of non-US persons who trade with US persons. ${ }^{1}$

Given the probable costs and burdens of the US regulatory approach, it is likely that both non-US persons and US persons will try to trade OTC derivatives in less-regulated jurisdictions. Failure to control this regulatory arbitrage may result in trading, that was previously being done in the US, moving to darker corners of the already opaque global OTC derivatives market. To control

\footnotetext{
* Associate Dean for Academic Affairs and Professor of Law, University of Utah College of Law. The author gratefully acknowledges that the paper was supported by a grant from CME Group Foundation, administered by The Federalist Society for Law and Public Policy Studies. The views expressed herein are solely the views of the author.

1 See infra Part I.C.
} 
regulatory arbitrage, Dodd-Frank has endowed the CFTC and SEC with unprecedented extraterritorial jurisdiction to regulate the swap trading activities outside of the United States of non-US persons. ${ }^{2}$

A related concern of regulatory arbitrage, however, is the effect that it will have on the preeminence of the United States as one of the world's most important and innovative OTC derivative markets. The United States, and the CFTC in particular, appear to feel ambivalent about this result; instead transfixed on eliminating any possibility that OTC derivative losses could contribute to systemic financial risks in the United States. ${ }^{3}$

The CFTC's response to challenges that US derivative reforms (not in harmony with other jurisdictions) will make US firms and markets uncompetitive is threefold. First, the CFTC appears to believe that the resulting price transparency and increased safety of United States markets from Dodd-Frank reforms will make US markets even more attractive to non-US persons. Second, it appears that US regulators and policymakers believe that the size, importance, and profitability of US derivative markets will be more attractive to non-US swap dealers the regulatory costs being imposed by Dodd-Frank on both US and non-US participants. A lowly third on the totem pole appears to be compromising US rules to match those of less-regulated jurisdictions. ${ }^{4}$

Because of regulatory arbitrage, however, Dodd-Frank may instead turn the traditionally robust and innovative US OTC derivative market into an island, where the only participants are those that have no other options as to where and with whom they can trade. Even small regulatory differences between the United States and competing jurisdictions may be enough to move OTC derivative trading offshore. Instead of US dealers, exchanges, and clearinghouses leading the industry, the US market may become a safe, although smaller, backwater harbor. But such safety may be illusory if swap activity moves to unregulated markets that may, in the long run, have a systemic effect on the United States if such trading results in outsized losses.

The simplified analysis of the US approach to derivative reform is that the United States can protect itself from the potential systemic effects of losses from OTC derivative transactions through two ways. First, the Dodd-Frank reforms subject any OTC derivative transaction to US regulation that is executed with a US person. That would include trades not only between a US person and a US person but also trades between a US person and a non-US person. Under this scenario, the US financial system will not be subject to the risks of a US person entering into systemically dangerous trading since all trades will be subject to Dodd-Frank, regardless of where the swap is executed. 5

Second, the United States protects itself from the risks of non-US swap activities of non-US persons (who trade with US persons) by exercising extraterritorial jurisdiction. The CFTC will subject the swap activity of a non-US person (that is classified as a swap dealer or major swap participant under Dodd-Frank) to the Dodd-Frank rules or to the rules of a foreign jurisdiction

2 See infra Part II-III.

3 See infra Part II.

4 See infra Part I.B.

5 See infra Part III.C.3. 
that has rules comparable to Dodd-Frank, regardless of where in the world such trades are executed. The only true escape from the extraterritorial reach of the CFTC would be for swap activity to be done between two non-US parties, neither of whom is subject to either Dodd-Frank registration requirements or to comparable rules from another jurisdiction. ${ }^{6}$

A key factor in the potential success of the CFTC's approach is that the major global swap dealers, often referred to as the G14, control the vast majority of the global OTC derivative market. Each of the G14 also has significant trading operations in the United States. The United States has made it clear that if these dealers want to continue doing business in the United States, they will not only need to comply with Dodd-Frank with respect to their US customers, but they will also need to demonstrate that they are subject to comparable "Dodd-Frank" regulation of their derivative activities outside of the United States with non-US persons (or comply with US rules). The United States is gambling that this extraterritorial approach to regulation will result in DoddFrank effectively serving as a global floor of acceptable OTC derivative regulation. $^{7}$

The United States is not alone, however, in trying to reform OTC derivative markets. In 2009, the leaders of the individual G20 countries, which include the United States, agreed to require by 2012 that standardized OTC derivatives be traded on exchanges, cleared through central counterparties, and reported to trade repositories, with non-cleared bilateral trades subject to higher capital requirements and margin requirements as well (the "G20 Commitments"). Although the respective G20 countries have agreed to the commitments, the devil is always in the details. It is inevitable that regulatory differences will emerge between the United States and competing jurisdictions. By enacting rules and regulations that are stricter (or go beyond) those enacted by the other G20 countries, the United States risks pushing non-US persons away from US markets, and motivates US persons to devise ways to avoid US regulation. ${ }^{8}$

Given the uncertainty, complexity, business disruption, and cost of DoddFrank, there is concern that dealers and other market participants alike will attempt to structure their trading activities away from United States dealers, exchanges, and clearinghouses and into jurisdictions that are less restrictive and more flexible. Although this movement may initially be to other G20 jurisdictions, there is concern that there may develop OTC derivative markets in nonregulated jurisdictions that allow a party to trade OTC derivatives free (or on more liberal terms) of the rules, standards, and regulations developed in the United States and other G20 countries. ${ }^{9}$

The incentives to avoid US regulation through regulatory arbitrage are on their face compelling. Dodd-Frank regulation and the G20 Commitments effectively require market participants to completely change how they trade, settle, and clear OTC derivatives, demanding large amounts of additional margin, new relationships, documentation, and business practices. Many view the regula-

\footnotetext{
6 See infra Part III.

7 See infra Part III.B.

8 See infra Part I.C.

9 See infra Part II.
} 
tions as burdensome, costly, and excessive. The Dodd-Frank OTC derivative statutory provisions exceed 300 pages and the proposed and final rules and regulations issued by the CFTC already exceed 4,200 pages in the Federal Register. $^{10}$

The flip side of regulatory arbitrage, and the hope of the CFTC and US policymakers, is that these regulations and reforms will make OTC derivatives markets more transparent, safe, and efficient, and create incentives to trade and clear them in the United States as opposed to fleeing to less-regulated jurisdictions. Chairman Gary Gensler of the CFTC has highlighted the important advantages of transparency in the OTC derivative market. In fact, in spite of the enormous obstacles to clearing OTC derivatives, the volume of cleared OTC derivatives continues to increase even with Dodd-Frank regulations looming in the background. It remains unclear, however, whether these gains will incentivize market participants to continue using United States dealers, exchanges, and clearinghouses as the Dodd-Frank rules and regulations become effective in the United States. ${ }^{11}$

One regulatory approach that may contribute to the isolation of US markets is the potential unwillingness of the United States to allow a non-US person, (whether a swap dealer or not) to comply with its own comparable regulations (as opposed to Dodd-Frank Rules) when it is transacting swap activity in the United States. Although such non-US person would be allowed to comply with what is referred to as "substituted compliance" (i.e., its own jurisdiction's regulations) when it is transacting swap activity outside the United States, it could end up being subject to its own jurisdiction's regulations, as well as Dodd-Frank when it does business in the US. There are already indications that non-US persons may decide that such a situation makes US markets that much more unpalatable. ${ }^{12}$

The US approach, however, could eventually backfire. Confronted with what many believe to be costly and burdensome US regulations, many participants that do not have operations in the United States may now be reluctant to trade there. Those that do have operations in the United States may still try to trade elsewhere, attempting to exploit even tiny regulatory differences in other regulated jurisdictions or perhaps even shuttering their US activities in order to avoid more complex and costly regulation. It remains to be seen whether the United States and the other G20 countries will be able to completely harmonize their regulatory regimes, eliminating the possibility of regulatory arbitrage. New dealers (not subject to US or G20 jurisdiction) may also spring up to meet the demand of customers that do not want to be subject to US or even lesser G20 regulations.

Effecting the OTC derivative reforms envisioned by the United States and the G20 countries will require great attention and effort to avoid regulatory arbitrage. The reduction of Dodd-Frank and the G20 commitments to regulatory details will be difficult and still remains to be done for many G20 jurisdictions. Particularly contentious issues include margin (i.e., collateral) issues,

\footnotetext{
10 See infra Part II.

11 See infra Part I.B.

12 See infra Part III.C.2.
} 
exemptions and safe harbors from mandatory clearing and trading, and business conduct standards. Using these G20 objectives as a baseline, the United States has gone well beyond what many jurisdictions may have understood as the reach of these proposed reforms. ${ }^{13}$

If the United States persists in insisting on other jurisdictions conforming to US regulation or risk extraterritorial jurisdiction, the United States may find itself on the receiving end of the same medicine. Non-US jurisdictions may decide to impose their own extraterritorial jurisdiction on US swap dealers. Swap dealers such as Goldman Sachs and JPMorgan Chase may find themselves not only complying with Dodd-Frank in the United States, but also subject to inconsistent and perhaps contradictory G20 regulation imposed because of the US swap dealer's activities with non-US persons in a G20 jurisdiction.

Part I will discuss the rise of the global OTC derivative markets and the fears of regulators and policymakers that systemic risks to the US financial markets will stem from losses suffered from OTC derivatives. Part I continues to describe US and the G20's reform efforts to tame global OTC derivative markets.

Part II will focus on the nature and causes of regulatory arbitrage. In particular, Part II will discuss the unique characteristics and peculiarities of OTC derivative trades and markets that may trigger an exodus of trading and participants from US markets into less-regulated environments. It will also discuss examples of regulatory arbitrage in the OTC derivative markets and whether the resulting price transparency and safety of US derivative markets offset the high regulatory costs that motivate regulatory arbitrage.

Part III will discuss the CFTC's and other jurisdictions' efforts to deal with regulatory arbitrage through extraterritorial regulation, assessing whether these very efforts may affect the vitality and viability of US markets for trading OTC derivatives. If US regulation proves to be overly aggressive and possibly enacted earlier than that of other jurisdictions, the consequences could be severe. First, such regulation could discourage the use of the US OTC derivative markets if such regulation proves to be too costly or burdensome. The paradox of stricter regulation is that it could drive trading out of US markets into darker corners of the derivative markets where latent systemic risks to the US and global financial system could ferment. Second, extraterritorial application of Dodd-Frank could generate substantial legal uncertainty and confusion as parties attempt to cope with determining which jurisdiction's rules govern certain transactions. Finally, the effort to avoid US regulation could end up fragmenting global derivative markets and increasing trading and hedging costs for all participants.

Lastly, Part IV provides recommendations and ideas that the United States should consider to avoid the possible loss of OTC trading activity in US markets. Part IV will offer a way to analyze the trade-offs between increased regulation and regulatory arbitrage. It will also discuss how the United States should consider compromising its level of regulation with that of other jurisdictions, such as the other G20 countries. Finally, the paper will offer specific

13 See infra Part II.B. 
technical suggestions to the CFTC's final interpretive guidance that may help minimize regulatory arbitrage issues.

\section{Drive to Regulate OTC Derivatives}

To understand the current drive to create a uniform global regulatory structure of the regulation of OTC derivatives, it is important to understand the size and global nature of OTC derivatives. As regulators were confronted with the financial carnage from the Great Financial Crisis, policy makers and regulators feared that future systemic losses suffered in OTC derivative markets could ignite the next financial panic.

\section{A. Understanding OTC Derivatives}

Although OTC derivatives have been characterized as weapons of mass destruction by the great Omaha financial sage Warren Buffet, ${ }^{14}$ derivatives have always played an important role in commerce. They can provide a critical means for parties to hedge business risks and to speculate with respect to the future movement of prices and indexes. Historically, the most common types of derivatives were options and forward transactions. The derivatives market vastly expanded as parties used organized exchanges to trade futures and options on futures. ${ }^{15}$ Since the early 1980 s, the OTC derivatives market has provided parties with endless possibilities of hedging and speculating using OTC derivative transactions.

The general term "derivative" encompasses a wide variety of financial instruments. The classic definition of a derivative is "a financial contract whose value depends on the values of one or more underlying assets or indexes of asset values." 16 Derivatives can be divided into several categories. The most common and simplest division is between derivatives that are traded over organized exchanges ("exchange-traded derivatives") and those that are traded in the OTC market. Both of these markets are measured in the trillions of dollars and continue to grow in size and importance.

The exchange-traded derivatives industry is a mature and active financial market. The Bank for International Settlements (the "BIS") estimated that there were over 86.9 million open futures contracts as of June 2013, of which 27.6 million were entered into in North America. ${ }^{17}$ The outstanding notional amount

14 Warren E. Buffett, Berkshire Hathaway Inc., 2002 Annual Report 15 (2003).

15 The exchange-traded derivatives market is credited with beginning with the Chicago Board of Trade in Chicago in 1848. History of the CFTC: US Futures Trading and Regulation Before the Creation of the CFTC, U.S. Commodity Futures Trading Commission, http://www.cftc.gov/About/HistoryoftheCFTC/history_precftc (last visited Feb. 19, 2014).

16 Bd. of Governors of the Fed. Reserve Sys., Fed. Deposit Ins. Corp. \& Office of the Comptroller of the Currency, Derivative Product Activities of Commercial Banks: Joint Study Conducted in Response to Questions Posed by Senator Riegle on Derivative Products 2 (1993); see also U.S. Gen. Accounting Office, GAO/GGD94-133, Financial Derivatives: Actions Needed to Protect the Financial System 24 (1994).

17 Bank for Int'L Settlements, BIS Quarterly Review app. A, at 147 (2013), available at http://www.bis.org/publ/qtrpdf/r_qt1306.htm. 
of those trades is estimated by the BIS at $\$ 25.188$ trillion as of June $2013 .{ }^{18}$ The BIS further estimated that there were 144 million option contracts open, 45.6 million of which were entered into in North America. ${ }^{19}$

In the United States, futures and options on futures (and the accompanying exchanges and clearinghouses) are regulated by the CFTC. ${ }^{20}$ Currently there are eighteen exchanges (referred to as "Designated Contract Markets" by the CFTC) operating in the United States. ${ }^{21}$ Further, there are thirteen clearinghouses (referred to as "Derivatives Clearing Organizations" by the CFTC) in the United States that clear futures and options trades. ${ }^{22}$

Proponents of the proposed OTC derivative reforms believe that the reductions in credit risk, increased transparency, and price discovery in the exchange-traded market can be exported wholesale into the OTC derivative markets. Clearinghouses act as the intermediary between the buyer and seller. ${ }^{23}$ A clearinghouse greatly increases the usefulness of futures and options on futures by permitting parties to enter into trades without having to worry about the creditworthiness of their counterparty. Of course, the party is still subject to the credit risk that the clearinghouse may not perform. While there is an actual buyer and seller for each contract sold, the clearinghouse acts as an intermediary between the two parties, and actually steps into the shoes of the counterparty to the respective buyer or seller. ${ }^{24}$

Since the early 1980s, the OTC derivative market has developed outside of the exchange/clearinghouse environment. This market is dominated by large commercial banks, investment banks, and similar financial institutions that act as swap dealers for the other participants. Parties in this area trade a wide variety of different OTC derivative products. ${ }^{25}$ The growth and development of the

${ }^{18}$ Id. at app. A, at 146.

19 Id. at app. A, at 147.

20 See Mission and Responsibilities, U.S. Commodity Futures Trading Commission, http://www.cftc.gov/About/MissionResponsibilities/index.htm (last visited Feb. 20, 2014).

21 See Trading Organizations - Designated Contract Markets (DCM), U.S. CoмmodiTy Futures TRADING COMMISSION, http://sirt.cftc.gov/SIRT/SIRT.aspx?Topic=TradingOrgani zations\&implicit=true \&type $=$ DCM\&CustomColumnDisplay=TTTTTTTT (last visited Feb. 20, 2014).

22 Derivatives Clearing Organizations (DCO), U.S.commodity Futures Trading ComMISSION, http://sirt.cftc.gov/SIRT/SIRT.aspx?Topic=ClearingOrganizations\&implicit=true\& type $=$ DCO\&CustomColumnDisplay=TTTTTTTT (last visited Feb. 20, 2014).

${ }_{23}$ Clearing Organizations: Derivatives Clearing Organizations, U.S. Commodity Futures Trading Commission, http://www.cftc.gov/IndustryOversight/ClearingOrganizations/index .htm (last visited Feb. 20, 2014).

${ }^{24}$ Chatham Fin., The End-User Guides to Derivatives Regulation: Overview of Central Clearing 2 (2012), available at http://www.chathamfinancial.com/wp-content /uploads/2012/08/Chatham-Financial-Overview-of-Central-Clearing.pdf.

25 Comptroller of the Currency, OCC's Quarterly Report on Bank Trading and Derivatives Activities First QuARTer 20121 (2012), available at http://www.occ.gov /news-issuances/news-releases/2012/2012-96a.pdf. In soliciting legal opinions regarding the enforceability of OTC derivative transactions, the International Swaps and Derivatives Association ("ISDA") has developed the following comprehensive list (with definitions) of the various OTC derivative transactions that opining counsel is required to address. This list is generally considered to be comprehensive of the types of various transactions in the derivatives markets: basis swap; bond option; bullion option; bullion swap; bullion trade; cap transaction; collar transaction; commodity forward; commodity option; commodity swap; 
OTC derivative industry has been aided and fostered by the market's principal trade group, the International Swaps and Derivatives Association ("ISDA"). ${ }^{26}$

As the "buy side" (customers of the swap dealers) was demanding customized derivative products from dealers to meet hedging requirements and other needs, dealers became concerned that, under the Commodity Exchange Act, such products could be classified as illegal off-exchange future products. ${ }^{27}$ In an effort to enhance legal certainty and to determine regulatory jurisdiction over the nascent OTC derivatives market, political pressure was placed on the CFTC to exempt OTC derivatives from their regulatory jurisdiction. Through regulatory and larger Congressional action, OTC derivatives were exempted from CFTC regulation. ${ }^{28}$ As Gary Gensler, Chairman of the CFTC, noted, "[1] eading up to the financial crisis, swaps were basically not regulated in Asia, Europe or the United States." ${ }^{29}$ US banks, however, were at least subject to prudential regulation. ${ }^{30}$

credit spread transaction; cross currency rate swap; currency option; currency swap; equity forward; equity index option; equity option; equity swap; floor transaction; foreign exchange transaction; forward rate transaction; interest rate option; interest rate swap; physical commodity transaction; swap option; total return swap; weather index transaction. Memorandum from Mayer Brown Law Firm on the Enforceability of the Termination, Close-Out and Multibranch Netting Provisions of the 1987, 1992 and 2002 Editions of ISDA Master Agreements for the Int'l Swaps and Derivatives Ass'n, app. A, at 1-5 (Mar. 13, 2012) (on file with author).

${ }^{26}$ About ISDA, ISDA, http://www2.isda.org/about-isda (last visited Feb. 20, 2014); see also John Biggins \& Colin Scott, Public-Private Relations in a Transnational Private Regulatory Regime: ISDA, the State and OTC Derivatives Market Reform, 13 Eur. Bus. Org. L. Rev. 309, 309 (2012); Sean M. Flanagan, The Rise of a Trade Association: Group Interactions Within the International Swaps and Derivatives Association, 6 Harv. Negot. L. Rev. 211, 240-41 (2001).

27 See Steven Lofchie et al., What Is a "Swap" and Other Jurisdictional Questions?, CADwALADER CABINET (April 3, 2012), http://www.cadwalader.com/thecabinet/page.php?page _id $=33 \#$ What $\% 20$ the $\% 20$ CFTC $\% 20$ has $\% 20$ Jurisdiction $\% 20$ Over $\% 20$ and $\% 20$ Why $\% 20 \mathrm{It} \%$ 20Matters.

28 See CFTC Policy Statement Concerning Swap Transactions, 54 Fed. Reg. 30,694 (July 21, 1989). The CFTC distinguished OTC derivatives from futures based partly on the fact that OTC trades are individually tailored, are not marketed to the general public, and lack exchange derivative characteristics such as exchange-style offset and clearing. In 1993, the CFTC further confirmed the regulatory division between OTC derivatives and exchangetraded derivatives when it promulgated regulations that exempted OTC derivatives from CFTC jurisdiction, provided again that the OTC transactions were substantively different from exchanged-traded transactions that the Commodity Exchange Act was designed to cover. $I d$. at 30,695. One important difference was that the transactions were not "standardized as to their material . . terms . . ." Commodity Options and Agricultural Swaps, 76 Fed. Reg. 6,095, 6,097 n.23 (Feb. 3, 2011) (emphasis added).

${ }^{29}$ Gary Gensler, Chairman, U.S. Commodity Futures Trading Comm'n, Keynote Address on the Cross-Border Application of Dodd-Frank Swaps Market Reforms before the 2012 FINRA Annual Conference (May 21, 2012), available at http://www.cftc.gov/PressRoom /SpeechesTestimony/opagensler-113.

30 See Memorandum from the Comptroller of the Currency, Adm'r of Nat'l Banks, on the Risk Management of Financial Derivatives to the Chief Exec. Officers of Nat'l Banks, Gen. Managers of Fed. Branches and Agencies, Deputy Comptrollers, Dep't and Div. Heads, and Examining Pers. 1 (Oct. 27, 1993) (on file with author), issued by the OCC in 1993, for an example of the requirements that banks acting as dealers are required to meet. 
The OTC derivatives market has experienced nothing short of explosive growth since the early 1980s. ${ }^{31}$ The total notional amount outstanding as of the end of 2012 (the most recent data) for OTC derivatives was estimated by the BIS to be approximately $\$ 633$ trillion. ${ }^{32}$ The gross market value of these trades was estimated at $\$ 24.7$ trillion with the gross credit exposure calculated to be $\$ 3.6$ trillion. $^{33}$

To understand the current OTC derivative reforms, it is important to understand that the key reforms of exchange trading and clearing through clearinghouses find their root and motivations in the exchange-traded derivative world. There, collateral is king and the trading of futures, options on futures, and options is only done through regulated exchanges and cleared through clearinghouses.

In the great debate over OTC derivative regulation, politicians, regulators, and pundits regularly bolster their cases for regulation by trumpeting the size as measured by the notional amount of the global OTC derivative market. By citing to the $\$ 633$ trillion notional amount statistic, however, they render any rational discussion about the true risks of the OTC derivative industry almost meaningless, the number is simply too large to grasp. ${ }^{34}$ It is important to understand that the notional amount does not provide a direct indication of the amount that can be lost in these markets. The notional amount instead refers to the reference amount that payments in a derivative transactions are based upon. ${ }^{35}$ For example, an interest rate swap payment would be calculated by multiplying the relevant rate by the notional amount (which typically would reference the amount of the liability that was being hedged).

Gross market value instead represents the mark-to-market value of all of the outstanding transactions as of the end of 2012. ${ }^{36}$ This is typically explained as the amount that would be paid by one party to another party at a particular point in time if the OTC derivatives were to be terminated prior to maturity. Although \$24.7 trillion is an extraordinarily large number as well, it does not take into account the effect of close-out netting. ${ }^{37}$

31 Henry T. C. Hu, Keynote Address: The SEC, Dodd-Frank, and Modern Capital Markets, 7 N.Y.U. J.L. \& Bus. 427, 427 (2011). For a general description and discussion of the derivatives market, see 6 Christian A. Johnson, Learning Curves: A Guide to Using and Negotiating OTC Derivatives Documentation 1-18 (2005).

32 Monetary and Econ. Dep't, Bank for Int'l Settlements, Statistical Release: OTC Derivatives Statistics at End-December 2012, at 1 (2013), available at http:// www.bis.org/publ/otc_hy1305.pdf. These statistics represent the size of the OTC derivative market in the G10 countries (in addition to Switzerland).

33 Id.

$34 \mathrm{Id}$.

35 Deutsche Börse Grp., The Global Derivatives Market: An Introduction 38 (2008), available at http://www.math.nyu.edu/faculty/avellane/global_derivatives_market .pdf.

36 Bank For Int'l Settlements, BIS Quarterly Review: International Banking AND Financial Market Developments 24 (2007), available at http://www.bis.org/publ/qtrpdf /r_qt0712.pdf.

37 Int'l Swaps and Derivatives Ass'n, OTC Derivatives Market Analysis Year-End 2012, at 3, 9 (2013), available at http://assets.isda.org/media/467fbf64/438d9f0f.pdf/. 
Finally, the gross credit exposure of $\$ 3.6$ trillion represents the net amount that would be payable, after taking into account close-out netting. ${ }^{38}$ This is the amount of net exposure that participants in the OTC markets have to each other, that could be lost in the event that parties (and the global OTC derivative financial markets) are at risk, and that is typically collateralized. ${ }^{39}$

\section{B. Global OTC Derivatives Markets and Systemic Risk}

OTC derivatives were initially developed to help parties manage various business risks. For example, one of the first publicly-reported swaps was used to help the World Bank and IBM manage foreign exchange risk through a foreign exchange swap. ${ }^{40}$ Although, given the size of the OTC derivative market, it could be argued that the industry has an exemplary record, there are numerous historical examples of failures to which critics continue to call attention. As the recent Great Financial Crisis continued to drag on, regulators and policy makers began to focus on eliminating the perceived dangers of OTC derivatives.

Commissioner Gensler ${ }^{41}$ has been consistent is his rallying cry to regulate: "And we must not forget the lessons of the 2008 crisis and earlier. Swaps executed offshore by U.S. financial institutions can send risk straight back to our

38 Id.

39 ISDA estimates that "collateral in circulation in the uncleared OTC Derivatives Market" was \$3.6 trillion at end of 2011. Int'L Swaps AND Derivatives Ass'N, ISDA Margin SuRVEY 2012, at 3 (2012), available at http://www2.isda.org/functional-areas/research /surveys/margin-surveys/.

40 World Bank: The IBM Deal that Opens a Cash Source, Bus. Wк., Sept. 7, 1981, at 48; World Bank Arranges Borrowing in Europe Totaling \$290 Million, Wall Sт. J., Aug. 12, 1981, at 34; I.B.M. in Deal on Currency, N.Y. Times, Aug. 18, 1981, at D10; Swapping Currencies with the World Bank, Institutional Investor, Dec. 1981, at 133.

${ }^{41}$ Gary Gensler's term as Commissioner of the CFTC technically ended in April, but "Federal rules permit Gensler, a Democrat, to remain as chairman of the commission until the end of 2013." Silla Brush, CFTC's Gensler Interested in Second-Term as Derivatives Overseer, BloOMBerg Businessweek (Oct. 12, 2012), http://www.businessweek.com/news/2012-10 -12/cftc-s-gensler-interested-in-second-term-as-derivatives-overseer. Gary Gensler in many ways was a peculiar choice to lead the charge in reforming OTC derivative markets. Having made partner at age 30 at Goldman Sachs, many might worry that he would become a pawn of Wall Street, putting his considerable talents to watering down reform. Ironically now, Chairman Gensler "worked alongside Robert E. Rubin, then the Treasury secretary under President Clinton, and Alan Greenspan, then the chairman of the Federal Reserve, to block proposals by the commission to regulate the new [derivative] instruments." Edmund L. Andrews, Obama Names Insider to Commodities Post, N.Y. Times, Dec. 19, 2008, at B3, available at $\mathrm{http}: / / \mathrm{www}$. nytimes.com/2008/12/19/business/19gensler.html?_r=0. His collective experience over time, however, with investment banks and swap dealers, appears to have instead turned him into a crusader for reform, sensitizing him to the risks of gutting regulation through exceptions and safe harbors. The various regulations written by the CFTC appear to have become longer and more complicated in an effort to avoid evasion by sophisticated and experienced investment bankers. Although universally recognizable by everyone in the derivative industry, the New Republic still listed him as one of Washington's Most Powerful, Least Famous People. Editorial, Washington's Most Powerful, Least Famous People, New RePublic (Oct. 12, 2011), http://www.newrepublic.com//article/politics/96131 /washingtons-most-powerful-least-famous-people. 
shores." 42 He has repeatedly warned that "risk from foreign deals flows back to U.S. firms." 43 Historically, there have been numerous infamous examples of companies suffering severe losses caused by the misuse of OTC derivatives, including the losses suffered by counterparties such as Proctor \& Gamble and Gibson Greeting Cards during the 1990s. ${ }^{44}$ These losses were followed by the exponentially higher OTC derivative losses suffered by several hedge funds, including Long Term Capital Management. ${ }^{45}$

The Lehman Brothers insolvency in 2008, in particular, gave regulators great pause, even though Lehman Brothers was in the money on a net basis with respect to its derivative book when it declared bankruptcy:

Lehman's derivatives receivables total $\$ 23.8$ billion and payables total $\$ 13.0$ billion, in each case based on marks net of collateral as of September 12, 2008. There are over 6,100 counterparties, 3,930 of which are expected to owe Lehman money and 2,190 of which are expected to be owed money by Lehman based on the estimated receivables and payables. ${ }^{46}$

Even four years later, substantial mediation and litigation is still ongoing to examine the valuation of the terminated trades. ${ }^{47}$

The sheer number of Lehman counterparties that actively traded with Lehman also added to the concern for the complexity and interconnectedness inher-

42 Gary Gensler, Chairman, U.S. Commodity Futures Trading Comm'n, Oral Testimony Before the U.S. House Financial Service Committee (June 19, 2012), available at http:// www.cftc.gov/PressRoom/SpeechesTestimony/opagensler-117b.

43 Vladimir Guevarra, EU, Japan Warn Against New US Swaps Rules, Wall St. J. (Oct. 18, 2012, 12:32 PM), http://online.wsj.com/news/articles/SB10000872396390444734804578 064600691285288 .

44 There are a growing number of companies that have suffered devastating losses as a result of their derivatives activities. For example, Procter \& Gamble Co. lost $\$ 157$ million on derivatives tied to movements in the yields "on five-year U.S. Treasury notes and the price of 30-year U.S. Treasury Bonds." Jeffrey Taylor \& Steven Lipin, Bankers Trust Faces Inquiry on Derivative Sales, WAll St. J., Nov. 1, 1994, at C1. Other companies such as Air Products \& Chemicals, Gibson Greetings Inc., and Mead have all lost tens of millions of dollars by entering into derivatives that moved against them. James P. Miller, Air Products Takes a Charge of $\$ 60$ million --- Move Reflects Falling Value of Derivative Contracts Sold by Banks Trust, Wall St. J., May 12, 1994, at A3. Although Air Products lost $\$ 107$ million in 1994, it did receive a settlement payment of $\$ 67$ million from Bankers Trust after it sued Bankers Trust with respect to the transactions. Timothy L. O'Brien, Bankers Trust Pays $\$ 67$ Million to Settle Derivatives Dispute with Chemical Firm, Wall St. J., Jan. 25, 1996, at A5. Although Gibson Greetings eventually only paid \$6.2 million of the \$23 million that it owed to Bankers Trust through a court settlement, it is still indicative of the great potential for losses. Steven Lipin \& Jeffrey Taylor, Bankers Trust Signs Accord on Derivatives --- Pact with New York Fed Toughens Supervision Affecting Sales Practices, Wall St. J., Dec. 6, 1994, at A3.

45 Roger Lowenstein, When Genius Failed: The Rise and Fall of Long-Term Capital Management 158-59 (2000).

46 Meet Lehman's Liquidators: Alvarez \& Marsal to Liquidate Investment Bank, Reconcile Derivative Claims, Teigland-Hunt 3 (Jan. 28, 2009), http://www.teiglandhunt.com/webcp /assets/rtarticles/pdf/55.pdf; see also Alvarez \& Marsal, LlC, Lehman Brothers Holdings InC.: The State of the Estate (2009), available at http://www.edocr.com/doc/3677 /lehman-brothers-holdings-inc-state-estate-january-14-2009.

47 Steven J. Fink et al., Lehman Derivative Litigation Still Looms Large, Law360 (June 14, 2013, 6:21 PM), http://www.law360.com/articles/450530/lehman-derivative-litigation-still -looms-large. 
ent in the market. ${ }^{48}$ Regulators portray the difficulties in unwinding the Lehman Brothers book as a poster child for the transparency, pricing, and credit concerns inherent in OTC derivatives. ${ }^{49}$ In addition to the sheer size of Lehman Brothers, there were also enormous amounts of activity between its domestic and international affiliates. The Joint Administrators of Lehman Brothers International (Europe) ("LBIE") estimated that there were several hundred interaffiliate balances between LBIE and the other affiliates. ${ }^{50}$ In addition to this inter-affiliate activity, LBIE itself had over "130,000 swaps contracts outstanding when it failed." 51

These losses paled, however, in comparison with the losses suffered by global insurance giant AIG on positions it had taken selling credit derivatives ${ }^{52}$ through its finance subsidiary, AIG Financial Products. ${ }^{53}$ As of 2008, its credit default swap ("CDS") portfolio totaled $\$ 447$ billion in notional amount and covered "super senior" risk tranches of diversified pools of loans and debt securities. ${ }^{54}$ More problematic was that counterparties' exposure to AIG was uncollateralized due to faith in AIG's AAA credit rating. ${ }^{55}$ As of the nine months ending on September 30, 2008, AIG had unrealized market valuation losses on its AIGFP super senior credit default swap portion in the amount of $\$ 21.7$ billion. ${ }^{56}$ These, along with other losses, caused the Federal Reserve and the US Treasury to intervene and prevent AIG from failing.

Regulators recently became even more concerned about the safety of the bilateral OTC derivatives market when JPMorgan Chase experienced large

48 It is estimated that JP Morgan Chase has approximately 17,000 active counterparties represented in its OTC derivative trading book of business. Interview with Don Thompson, Assoc. Gen. Counsel, JPMorgan Chase (Apr. 9, 2010) (on file with author).

49 See Jon H. Harsch, CFTC Chair Gensler Calls for Regulating OTC Market to Protect Both Taxpayers and Derivatives Users, AgriPulse 1 (Jan. 7, 2010), http://www.agri-pulse .com/uploaded/Jan0710H2.pdf.

50 See Lehman Brothers International (Europe) in Administration: Joint Administrators' Progress Report for the Period 15 September 2008 to 14 March 2009, at 26 (2009), available at http://www.pwc.co.uk/assets/pdf/lbie-progress-report-140409.pdf.

51 Gensler, supra note 29.

52 See Frank Partnoy \& David A. Skeel, Jr., The Promise and Perils of Credit Derivatives, 75 U. Cin. L. Rev. 1019, 1021 (2007); About CDS: CDS FAQ, ISDA, http://www.isdacds marketplace.com/about_cds_market/cds_faq (last visited Feb. 4, 2014).

53 For a general discussion of the AIG crisis, see generally Cong. Oversight Panel, June Oversight Report: The AIG Rescue, Its Impact on Markets, and the Government's EXIT STRATEgy (2010), available at http://www.gpo.gov/fdsys/pkg/CPRT-111JPRT56698 /pdf/CPRT-111JPRT56698.pdf; U.S. Gov't ACCOUnTABILITy OfFice, GAO-11-616, Financial Crisis: Review of Federal Reserve System Financial Assistance to American INTERNATIONAL GrouP, INC. (2011), available at http://www.gao.gov/assets/590/585560 .pdf.

54 William K. Sjostrom, Jr., The AIG Bailout, 66 WASh. \& LeE L. Rev. 943, 945 (2009); Am. Int'l Grp., Inc., Quarterly Report (Form 10-Q), at 100 (Nov. 10, 2008) [hereinafter AIG 2008 Report], available at http://media.corporate-ir.net/media_files/irol/76/76115/reports /Q308_10Q.pdf.

55 See Robert Oak, Yesterday AIG had a AAA Credit Rating, Econ. Populist (Sept. 17, 2008, 4:17 PM), http://www.economicpopulist.org/content/yesterday-aig-had-aaa-credit -rating.

56 Am. Int'l Grp., Inc., Quarterly Report (Form 10-Q), at 40 (Nov. 6, 2009), available at http://www.aig.com/Chartis/internet/US/en/2517447_17501T04_CNB_tcm3171-443244 .pdf. 
losses on credit default derivative trades in spring of 2012 executed by their trader affectionately referred to as the "London Whale." 57 The losses were particularly disturbing given that JPMorgan Chase is considered to be one of the best managed US banks and is the largest bank in the United States as measured by assets. ${ }^{58}$

On May 10, 2012, JPMorgan Chase announced a loss on their credit default trades of "about \$2 billion." 59 As JPMorgan Chase struggled to unwind these positions, the losses grew to $\$ 5.8$ billion and could potentially increase to as much as $\$ 7.5$ billion. ${ }^{60}$ When pressed about the losses, Jamie Dimon, the CEO of JPMorgan stated, "[i]n hindsight, this was bad execution, bad strategy, but also the environment - because this is mark to market . . . ." Dimon continued, "[b]ut I just don't want to make excuses." 61

In Chairman Gensler's continual push to enact OTC derivative regulatory reforms, he has repeatedly focused on the JPMorgan Chase losses: " Recent events at JPMorgan Chase are a stark reminder of how swaps traded overseas can quickly reverberate with losses coming back into the United States,' Mr. Gensler said. 'Now is not the time to retreat from these much-needed reforms.' "62

57 Andrew Trotman, JP Morgan Chief Jamie Dimon Defends Banks, Says London Whale has been 'Harpooned', TelegraPh (Aug. 13, 2012, 3:23 PM), http://www.telegraph.co.uk /finance/newsbysector/banksandfinance/9472835/JP-Morgan-chief-Jamie-Dimon-defends -banks-says-London-Whale-has-been-harpooned.html.

58 See id.

59 Dawn Kopecki, JPMorgan Erases Stock Drop Fueled by London Trading Loss, BLoomBERG News (Sept. 13, 2012, 4:00 PM), http://www.bloomberg.com/news/2012-09-13/jpmor gan-erases-stock-drop-fueled-by-london-trading-loss.html; Jessica Silver-Greenberg \& Peter Eavis, JPMorgan Discloses \$2 Billion in Trading Losses, N.Y. TiMEs (May 10, 2012, 10:11 PM), http://dealbook.nytimes.com/2012/05/10/jpmorgan-discloses-significant-losses-in-trad ing-group/. For a discussion of the losses, see James Dimon, Chairman and CEO, JPMorgan \& Chase, Testimony Before the U.S. Senate Committee on Banking, Housing and Urban Affairs (June 13, 2012), available at http://www.sec.gov/Archives/edgar/data/19617 /000119312512268992/d366030dex991.htm, and Nelson D. Schwartz \& Jessica SilverGreenberg, JPMorgan's Trading Loss is Said to Rise at Least 50\%, N.Y. Times (May 16, 2012, 9:14 PM), http://dealbook.nytimes.com/2012/05/16/jpmorgans-trading-loss-is-said-to -rise-at-least-50/.

${ }^{60}$ Kopecki, supra note 59; see also Mary Childs \& Shannon D. Harrington, Trading Surges Boosted Whale Positions Before Audits, Bloomberg (July 23, 2012, 9:00 PM), http://www .bloomberg.com/news/2012-07-24/trading-surges-boosted-whale-positions-before-audits .html; Maureen Farrell, JPMorgan's Trading Loss: \$5.8 Billion, CNN Money (July 18, 2012, 9:35 AM), http://money.cnn.com/2012/07/18/investing/jpmorgan-earnings/index.htm; Steve Schaefer, JPMorgan Profits Withstand \$4.4B Trading Loss, Forbes (July 13, 2012, 8:05 AM), http://www.forbes.com/sites/steveschaefer/2012/07/13/london-whales-4-4b-loss -cant-drown-jpmorgan-earnings/; Matt Scuffham \& Lionel Laurent, London Whale Took Big Bets Below the Surface, Reuters (May 11, 2012, 2:44 PM), http://www.reuters.com/article /2012/05/11/us-jpmorgan-iksil-idUSBRE84A12620120511.

${ }^{61}$ Charles Riley \& Julianne Pepitone, JPMorgan Suffers Big Loss, CNN Money (May 11, 2012, 9:37 AM), http://www.money.cnn.com/2012/05/10/news/companies/jp-morgan-losses /index.htm?iid=EL.

62 Ben Protess, Regulator May Grant Foreign Banks Brief Reprieve on Derivatives, N.Y. Times (June 14, 2012, 4:37 PM), http://dealbook.nytimes.com/2012/06/14/regulator-may -grant-foreign-banks-brief-reprieve-on-derivatives/?_r=0. 
In addition to avoiding systemic risks to the US financial system, the CFTC believes that the Dodd-Frank reforms will result in a "more transparent, accessible and competitive swaps market," noting that "transparency lowers the risk of the swaps market." 63 Chairman Gensler outlined in particular the advantages of transparency. First, it allows "the public and users of swaps to see the pricing and volume of transactions, as well as many bids and offers, in real time." ${ }^{4}$ Second, it allows "both dealers and end users the ability to look to markets to value positions, allowing for better supervision of and accounting for risk." Third, it provides greater liquidity when positions need to be unwound. ${ }^{65}$

Gensler further summarizes the transparency advantages of the DoddFrank reforms: "[T]ransparency lowers the risk of the swaps market. . . . Whether it's non-financial end users, pension funds, mutual funds, community banks or insurance companies, they all benefit from the lower costs and greater pricing information of a more transparent, accessible and competitive swaps market."

\section{Efforts to Regulate OTC Derivatives Pre-Dodd-Frank-Commitments} from Global Market Participants to the Federal Reserve and Other Foreign Regulators

Prior to the Dodd-Frank and G20 regulatory efforts, the Federal Reserve and other regulators made progress to regulate OTC derivatives and eliminate future systemic risk. As the OTC derivative market continued to grow, with the CDS market exploding in particular, regulators pushed the major swap dealers to reform their trading activities.

Beginning in 2005, the Federal Reserve Bank of New York, in conjunction with domestic and international supervisors, ${ }^{67}$ organized a committee referred to as the OTC Derivatives Supervisors Group "to address the emerging risks of inadequate infrastructure for the rapidly growing market in credit derivatives." ${ }^{68}$ Through a series of commitment letters addressed to these regulators

63 Gary Gensler, Chairman, U.S. Commodity Futures Trading Comm'n, Keynote Address on Dodd-Frank Swaps Market Reform at the Sandler O'Neill Global Exchange \& Brokerage Conference (June 7, 2012), available at http://www.cftc.gov/PressRoom/SpeechesTestimo ny/opagensler-115.

64 Id.

$65 \mathrm{Id}$.

66 Id.

67 The group eventually grew to include the following foreign regulators (in addition to US regulators): French Prudential Supervisory Authority (Autorité de Contrôle Prudentiel ACP); German Federal Financial Supervisory Authority; Japan Financial Services Agency; Swiss Financial Market Supervisory Authority; and the United Kingdom Financial Services Authority. See Commitment Letter from the Mgmt. of AllianceBernstein et al., to William C. Dudley, President, Fed. Reserve Bank of N.Y. 1 n.2 (Mar. 31, 2011), available at http:// www.newyorkfed.org/newsevents/news/markets/2011/SCL0331.pdf.

${ }^{68}$ For a discussion of the OTC Derivatives Supervisors Group and the commitment letters developed through this process, see OTC Derivatives Supervisors Group, Fed. Res. Bank N.Y., http://www.newyorkfed.org/markets/otc_derivatives_supervisors_group.html (last visited Feb. 20, 2014). 
from the largest global derivative dealers and buy-side participants, ${ }^{69}$ tremendous progress was made at reforming the CDS market. Unfortunately, as both regulators and participants have turned their attention toward the Dodd-Frank and G20 statutory reforms now being implemented, the group appears to be inactive.

\section{Dodd-Frank OTC Derivative Reforms}

Although there have been calls to regulate OTC derivatives in the United States since the early 1980s, the calls to regulators and the US Congress did not gain any traction until the Great Financial Crisis. ${ }^{70}$ As the financial crisis deepened, global policy makers and regulators began to look for sources of the next financial crisis.

The Great Financial Crisis in the United States officially began in December of 2007 when the United States entered into recession and did not climb out until June of $2009 .^{71}$ To appreciate the panic and concern of policymakers and regulators, it is important to consider some of the key statistics during that time period. The Dow Jones Industrial Average peaked in October 2007, at 14,164, only to have plummeted to 6,547 by March of $2009 .^{72}$ Other stock indexes globally had similar results. ${ }^{73}$

69 This group grew to include AllianceBernstein; Bank of America-Merrill Lynch; Barclays Capital; Blackrock, Inc.; BlueMountain Capital Management LLC; BNP Paribas; Citadel LLC; Citi; Credit Suisse; Deutsche Bank AG; D.E. Shaw \& Co., LP; DW Investment Management LP; Goldman, Sachs \& Co.; Goldman Sachs Asset Management, LP; HSBC Group; International Swaps and Derivatives Association, Inc.; JP Morgan; Managed Funds Association; Morgan Stanley; Pacific Investment Management Company, LLC; The Royal Bank of Scotland Group; Asset Management Group of the Securities Industry and Financial Markets Association; Société Générale; UBS AG; Wells Fargo Bank, NA; Wellington Management Company, LLP. See Commitment Letter from the Mgmt. of AllianceBernstein et al., to William C. Dudley, supra note 66, at 3.

70 See Daria S. Latysheva, Taming the Hydra of Derivatives Regulation: Examining New Regulatory Approaches to OTC Derivatives in the United States and Europe, 20 CARDOZO J. INT'L \& Comp. L. 465, 476-80 (2012); see also Frank D'Souza et al., Illuminating the Need for Regulation in Dark Markets: Proposed Regulation of the OTC Derivatives Market, $12 \mathrm{U}$. PA. J. Bus. L. 473, 476 (2010).

71 US Business Cycle Expansions and Contractions, Nat'L Bureau Econ. Res. (Apr. 23, 2012), http://www.nber.org/cycles/US_Business_Cycle_Expansions_and_Contractions_ 20120423.pdf.

72 Dow Jones Industrial Average (1900 - Present Monthly), SтоскСнавтs.сом, http:// stockcharts.com/freecharts/historical/djia1900.html (last updated Nov. 1, 2013).

73 The UK FTSE 100 went from a high on October 12, 2007, of $6,730.70$ to $3,460.70$ on March 9, 2009. FTSE 100: Historical Prices, YAHOO Fin., http://uk.finance.yahoo.com/q/hp $? \mathrm{~s}=\% 5 \mathrm{EFTSE} \& \mathrm{~b}=12 \& \mathrm{a}=09 \& \mathrm{c}=2007 \& \mathrm{e}=12 \& \mathrm{~d}=09 \& \mathrm{f}=2007 \& \mathrm{~g}=\mathrm{d}$ (last visited Feb. 20, 2014) (Oct. 12, 2007) (high); FTSE 100: Historical Prices, YaHOo FIN., http://uk.finance.ya hoo.com/q/hp?s=\%5EFTSE $\& \mathrm{~b}=9 \& \mathrm{a}=02 \& \mathrm{c}=2009 \& \mathrm{e}=9 \& \mathrm{~d}=02 \& \mathrm{f}=2009 \& \mathrm{~g}=\mathrm{d}$ (last visited Feb. 20, 2014) (Mar. 9, 2009) (low). The German DAX went from a high of $8,117.79$ on December 12, 2007, to a low of 3,588.89 on March 9, 2009. DAX: Historical Prices, YAноO FIN., http://finance.yahoo.com/q/hp? $=\% 5$ EGDAXI $\& \mathrm{a}=11 \& \mathrm{~b}=12 \& \mathrm{c}=2007 \& \mathrm{~d}=11 \& \mathrm{e}=12 \& \mathrm{f}$ $=2007 \& \mathrm{~g}=\mathrm{d}$ (last visited Feb. 20, 2014) (Dec. 12, 2007) (high); DAX: Historical Prices, YAноо FIN., http://finance.yahoo.com/q/hp?s=\%5EGDAXI\&a=02\&b=9\&c=2009\&d=02\&e $=9 \& \mathrm{f}=2009 \& \mathrm{~g}=\mathrm{d}$ (last visited Feb. 20, 2014) (Mar. 9, 2009) (low). The Hong Kong Hang Seng index went from a high of 30,922.31 on November 2, 2007, to a low of 11,344.58 on March 9, 2009. Hang Seng Index: Historical Prices, YАноо Fin., http://finance.yahoo.com 
Other indicators were equally as grim. Unemployment peaked at 10 percent in October of 2009, with the employment rate stubbornly remaining above 8 percent. ${ }^{74}$ Citigroup experienced a $\$ 17$ billion loss in the fourth quarter of 2008 , with its share price dropping from $\$ 23.84$ as of April 1, 2008, to $\$ 1.03$ as of March 6, 2009. ${ }^{75}$ The global financial markets experienced a liquidity crisis unequalled since the Great Depression. ${ }^{76}$

After the trauma experienced during the months of September and October 2008 , the US Treasury began to proactively propose the regulation of OTC derivatives in the United States. On May 13, 2009, in a seminal letter to Senator Harry Reid, US Treasury Secretary Timothy F. Geithner proposed a rationale and framework for regulating OTC derivatives. ${ }^{77}$ In the letter, Geithner outlined four broad objectives: "(1) preventing activities in those markets from posing risk to the financial system; (2) promoting the efficiency and transparency of those markets; (3) preventing market manipulation, fraud, and other market abuses; and (4) ensuring that OTC derivatives are not marketed inappropriately to unsophisticated parties."78

In his letter to Senator Reid, US Treasury Secretary Geithner outlined that the nature of the proposed regulation included clearing standardized OTC derivatives through regulated central counterparties; prudential supervision and regulation, including conservative capital requirements, business conduct standards, reporting requirements, and initial margins for unclear trades; record keeping and reporting requirements; and granting of additional authority to the CFTC and SEC to police fraud, market manipulation, and other market abuses. $^{79}$

$/ \mathrm{q} / \mathrm{hp} ? \mathrm{~s}=\% 5$ EHSI $\& \mathrm{a}=10 \& \mathrm{~b}=02 \& \mathrm{c}=2007 \& \mathrm{~d}=10 \& \mathrm{e}=02 \& \mathrm{f}=2007 \& \mathrm{~g}=\mathrm{d}$ (last visited Feb. 20, 2014) (Nov. 2, 2007) (high); Hang Seng Index: Historical Prices, Y Aноo Fin., http://finance .yahoo.com $/ \mathrm{q} / \mathrm{hp}$ ? $\mathrm{s}=\% 5 \mathrm{EHSI} \& \mathrm{a}=02 \& \mathrm{~b}=09 \& \mathrm{c}=2009 \& \mathrm{~d}=02 \& \mathrm{e}=09 \& \mathrm{f}=2009 \& \mathrm{~g}=\mathrm{d}$ (last visited Feb. 20, 2014) (Mar. 9, 2009) (low). The Australian S \& P ASX 200 went from a high of 6770.60 on October 12, 2007, to a low of 3120.80 on March 10, 2009. S\&P/ASX 200: Historical Prices, YAHOO Fin., http://finance.yahoo.com/q/hp?s=\%5EAXJO\&a=09\&b=12\& $\mathrm{c}=2007 \& \mathrm{~d}=09 \& \mathrm{e}=12 \& \mathrm{f}=2007 \& \mathrm{~g}=\mathrm{d}$ (last visited Feb. 20, 2014) (Oct. 12, 2007) (high); S\&P/ASX 200: Historical Prices, YAHOo FIN., http://finance.yahoo.com/q/hp?s=\%5EAXJO $\& \mathrm{a}=02 \& \mathrm{~b}=10 \& \mathrm{c}=2009 \& \mathrm{~d}=02 \& \mathrm{e}=10 \& \mathrm{f}=2009 \& \mathrm{~g}=\mathrm{d}$ (last visited Feb. 20, 2014) (Mar. 10, 2009) (low).

74 Databases, Tables \& Calculators By Subject: Labor Force Statistics from the Current Population Survey, Bureau LAB. StAT., http://data.bls.gov/timeseries/LNS14000000 (last visited Feb. 20, 2014).

75 Citigroup, Citi Annual Report 2008, at 225 (2008), available at http://www.citigroup .com/citi/investor/quarterly/2009/ar08c_en.pdf?ieNocache=714; Historical Quotes: Citi group Inc. Tue, Apr 01, 2008, BIG CHARTS, http://bigcharts.marketwatch.com/historical/de fault.asp? symb $=\mathrm{C} \&$ closeDate $=4 \% 2 \mathrm{~F} 01 \% 2 \mathrm{~F} 08 \& \mathrm{x}=40 \& \mathrm{y}=25$ (last visited Feb. 4, 2014); Historical Quotes: Citigroup Inc., Fri, Mar 06, 2009, http://bigcharts.marketwatch.com/histori $\mathrm{cal} /$ default.asp? symb $=\mathrm{C} \&$ closeDate $=3 \% 2 \mathrm{~F} 6 \% 2 \mathrm{~F} 09 \& \mathrm{x}=-563 \& \mathrm{y}=-296$ (last visited Feb. 4, 2014).

${ }^{76}$ For a discussion of the liquidity crisis and the Federal Reserve's efforts to stop the credit markets from imploding, see generally Christian A. Johnson, Exigent and Unusual Circumstances: The Federal Reserve and the US Financial Crisis, in Law Reform and Financial Markets 269, 269-70 (Kern Alexander \& Niamh Moloney eds., 2011).

77 Letter from Timothy F. Geithner, Sec'y, U.S. Dept. of Treasury, to Harry Reid, Senator, U.S. Senate (May 13, 2009).

$78 \mathrm{Id}$. at 1.

${ }^{79} I d$. at $1-2$. 
The US Treasury's proposals eventually found their way into US law in the form of the Dodd-Frank Wall Street Reform and Consumer Protection Act. ${ }^{80}$ The final passage of Dodd-Frank was an arduous process beginning in December of 2009 and running through final passage in May of $2010 .^{81}$

A complex piece of legislation, Dodd-Frank consists of sixteen Titles running over a thousand pages. Title VII, entitled Wall Street Transparency and Accountability, the statutory framework for regulating OTC derivatives in the United States, provides over three hundred pages of detailed statutes, broken into two subtitles containing a total of fifty-nine sections. ${ }^{82}$

The breadth of regulation enacted by the US Congress found in Title VII is breathtaking, completely overtaking and exceeding the regulation called for in the G20 Pittsburgh commitments. The new statutory framework requires mandatory exchange trading and clearing of OTC derivatives (with certain key exceptions), ${ }^{83}$ position limits, ${ }^{84}$ margining unclear swaps, ${ }^{85}$ capital requirements for dealers, ${ }^{86}$ the infamous Lincoln push-out, ${ }^{87}$ registration of swap dealers and major swap participants ${ }^{88}$ reporting and record keeping requirements, ${ }^{89}$ price discovery, ${ }^{90}$ business conduct standards, ${ }^{91}$ clearinghouse regulation and core principles, ${ }^{92}$ data repositories, ${ }^{93}$ conflict of interest rules, ${ }^{94}$ certain other miscellaneous provisions, and the provisions governing regulatory arbitrage.

The goal of US regulation appears to be to minimize to the greatest extent possible any risk of systemic failure from OTC derivative trading with US per-

80 Dodd-Frank Wall Street Reform and Consumer Protection Act, Pub. L. No. 111-203, 124 Stat. 1376 (2010) [hereinafter "Dodd-Frank Act" or "Dodd-Frank"].

81 In December 2009, the House bill passed. Wall Street Reform and Consumer Protection Act of 2009, H.R. 4173, 111th Cong. (2009). Five months later, the Senate passed on May 20, 2010, the Restoring American Financial Stability Act of 2010, S. 3217, 111th Cong. (2010). President Obama on July 21, 2010 signed into law the conference committee version. Dodd-Frank Act, 124 Stat. 1376.

82 Dodd-Frank Act $\S 1(\mathrm{~b})$ (table of contents showing number of Titles, Subtitles, and sections).

83 Dodd-Frank Act $\S 723$ (codified as amended at 7 U.S.C. $\S 2(\mathrm{~h})$ (2012)) (necessitated the exchange trading through Swap Execution Facilities requirement).

${ }^{84}$ Dodd-Frank Act $\S 737$ (codified as amended at 7 U.S.C. $§ 6 a(a)$ (2012)) [hereinafter Dodd-Frank Act Position Limits].

85 Dodd-Frank Act $\S 731$ (codified as amended at 7 U.S.C. $\S 6 \mathrm{~s}(\mathrm{e})$ (2012)) [hereinafter Dodd-Frank Act Unclear Swaps].

86 Id.

87 Dodd-Frank Act $\S 716$ (codified as amended at 15 U.S.C. $\S 8305$ (2012)).

88 Dodd-Frank Act $§ 731$ (codified as amended at 7 U.S.C. § 6s(a) (2012)); Dodd-Frank Act $\S 764$ (codified as amended at 15 U.S.C. $\S 780-8(a)(2012)$ ).

89 Dodd-Frank Act $§ 731$ (codified as amended at 7 U.S.C. § 6s(f) (2012)); Dodd-Frank Act $\S 764$ (codified as amended 15 U.S.C. § 78o-8(f) (2012)) [hereinafter Dodd-Frank Record Keeping].

90 Dodd-Frank Act $\$ 727$ (codified as amended at 7 U.S.C. $\S 2(a)(13)(B)$ (2012)); DoddFrank Act $\$ 763$ (codified as amended ay 15 U.S.C. $\S 78 \mathrm{~m}(\mathrm{~m})(1)(B)(2012)$ ).

91 Dodd-Frank Act $\$ 731$ (codified as amended at 7 U.S.C. $\$ 6 \mathrm{~s}(\mathrm{~h})$ (2012)); Dodd-Frank Act $§ 764$ (codified as amended at 15 U.S.C. $§ 78 \mathrm{o}-8(\mathrm{~h})(2012)$ ).

92 Dodd-Frank Act $\S 725$ (codified as amended at 7 U.S.C. $\S 7 \mathrm{a}-1$ (2012)).

93 Dodd-Frank Act $\$ 727$ (codified as amended at 7 U.S.C. $\$ 2(a)(13)(G)(2012)$ ); DoddFrank Act $\$ 763$ (codified as amended 15 U.S.C. $\$ 78 \mathrm{~m}(\mathrm{~m})(1)(\mathrm{G})(2012)$ ).

94 Dodd-Frank Act $\$ 726$ (codified as amended at 15 U.S.C. $\$ 8323$ (2012)); Dodd-Frank Act $§ 765$ (codified as amended at 15 U.S.C. $\S 8343$ (2012)). 
sons. It also seeks to minimize the risk that non-US persons doing business with US persons will enter into swap activity outside the United States that may cause such non-US persons to fail, thus perhaps causing systemic harm to US capital markets because of their inter-related connections to the United States.

\section{G20 Commitments}

It is impossible to understand the issues of regulatory arbitrage and extraterritoriality in global OTC derivative reform without understanding the efforts of the G20. The G20 is an informal group of nineteen countries and the European Union, with representatives of the International Monetary Fund and the World Bank. ${ }^{95}$ In addition to these annual meetings, there are also G20 summit meetings of the leaders of G20 countries held from time to time. ${ }^{96}$ Commentators in general have written favorably that the G20 has provided an important means to coordinate international efforts to regulate financial markets. ${ }^{97}$

Concern about global OTC derivative reform and regulatory arbitrage extended beyond the United States to include the other G20 countries as the financial crisis grew. In an effort to minimize or eliminate regulatory arbitrage, the G20 countries agreed to cooperate and harmonize international regulation of OTC derivatives in the Pittsburgh Summit, held September 24-25, 2009. ${ }^{98}$ In the 2009 G20 Leaders Statement, the G20 countries committed themselves to the following:

All standardized OTC derivative contracts should be traded on exchanges or electronic trading platforms, where appropriate, and cleared through central counterparties by end-2012 at the latest. OTC derivative contracts should be reported to trade repositories. Non-centrally cleared contracts should be subject to higher capital requirements. We ask the FSB [Financial Stability Board] and its relevant members to assess regularly implementation and whether it is sufficient to improve transparency in the derivatives markets, mitigate systemic risk, and protect against market abuse. $^{99}$

The G20 countries followed up on their 2009 commitments with an additional commitment in the 2011 Cannes Summit Final Declaration to create "organizations to develop for consultation standards on margining for non-cen-

95 The 19 countries include Argentina, Australia, Brazil, Canada, China, France, Germany, India, Indonesia, Italy, Japan, Mexico, Russia, Saudi Arabia, South Africa, Korea, Turkey, United Kingdom, and the United States. G20 Research Grp., G20 Members, U. Toronto, http://www.g20.utoronto.ca/members.html (last visited Feb. 20, 2014).

96 G20 Research Grp., The G20, U. Toronto, http://www.g20.utoronto.ca/g20whatisit.html (last visited Feb. 20, 2014).

97 Sungjoon Cho \& Claire R. Kelly, Promises and Perils Of New Global Governance: A Case Of The G20, 12 Chi. J. InT'L L. 491 (2012); Arie C. Eernisse, Banking on Cooperation: The Role of the G-20 in Improving the International Financial Architecture, 22 DukE J. Comp. \& InT'L L. 239 (2012); Gabriela I. Ramos, The OECD in the G20: A Natural Partner in Global Governance, 43 GEO. WASH. INT'L L. Rev. 325 (2011); Nathalie Boschat \& Ian Talley, Recovery Redefines G-20 Challenge, Wall St. J., Feb. 14, 2011, at A4.

${ }^{8}$ G20 Research Grp., G20 Leaders Statement: The Pittsburgh Summit, U. ToRonto, http:// www.g20.utoronto.ca/2009/2009communique0925.html (last visited Feb. 20, 2014); see also The Pittsburgh Summit: Key Accomplishments, White House 1-2, http://www.whitehouse .gov/files/documents/g20/Fact_Sheet_Pittsburgh_Outcomes.pdf (last visited Feb. 20, 2014). 99 G20 Research Grp., supra note 98. 
trally cleared OTC derivatives by June 2012." ${ }^{100}$ The key additional commitment that came out of the Cannes Summit was a commitment to require margining for non-cleared OTC derivatives. ${ }^{101}$ The G20 leaders again reiterated their commitment in the 2012 Los Cabos Leaders Declaration. ${ }^{102}$

There have been two key reports in measuring the progress of G20 countries. The first is a series of interim reports prepared by the Financial Stability Board, more commonly known as the FSB. The second was a joint report prepared by the CFTC and SEC in the United States. Both reports indicate some progress, but also that substantial work needs to be done by the G20 countries to meet both the 2012 deadline and their G20 commitments.

The FSB has been charged with monitoring the progress of the implementation of OTC derivative market reforms. The FSB is an organization that is hosted by the BIS and was "established to coordinate at the international level the work of national financial authorities and international standard setting bodies and to develop and promote the implementation of effective regulatory, supervisory and other financial sector policies." 103 The membership of the FSB

100 G20 Research Grp., Cannes Summit Final Declaration-Building Our Common Future: Renewed Collective Action for the Benefit of All, U. Toronto, http://www.g20.utoronto.ca /2011/2011-cannes-declaration-111104-en.html (last visited Feb. 20, 2014). The full statement reads as follows:

Reforming the over the counter derivatives markets is crucial to build a more resilient financial system. All standardized over-the-counter derivatives contracts should be traded on exchanges or electronic trading platforms, where appropriate, and centrally cleared, by the end of 2012; OTC derivatives contracts should be reported to trade repositories, and non-centrally cleared contracts should be subject to higher capital requirements. We agree to cooperate further to avoid loopholes and overlapping regulations. A coordination group is being established by the FSB to address some of these issues, complementing the existing OTC derivatives working group. We endorse the FSB progress report on implementation and ask the CPSS and IOSCO to work with FSB to carry forward work on identifying data that could be provided by and to trade repositories, and to define principles or guidance on regulators' and supervisors' access to data held by trade repositories. We call on the Basel Committee on Banking Supervision (BCBS), the International Organization for Securities Commission (IOSCO) together with other relevant organizations to develop for consultation standards on margining for non-centrally cleared OTC derivatives by June 2012, and on the FSB to continue to report on progress towards meeting our Id. commitments on OTC derivatives.

101 Id

102 We reaffirm our commitment that all standardized OTC derivative contracts should be traded on exchanges or electronic trading platforms, where appropriate, and cleared through central counterparties by end-2012, OTC derivative contracts should be reported to trade repositories and non-centrally cleared contracts should be subject to higher capital requirements. We welcome the FSB progress report on implementation. Now that substantial progress has been achieved in the four safeguards for a resilient and efficient global framework for central clearing, jurisdictions should rapidly finalize their decision-making and put in place the needed legislation and regulations to meet the G20 commitment for central clearing. We acknowledge the progress made to develop the key principles to promote internationally consistent minimum standards for the margining of non-centrally cleared derivatives and encourage international standard setters to finalize the proposed global margin standards by the end of this year, to match the implementation deadline for other OTC derivatives reforms and for the Basel capital framework.

G20, G20 Leaders Declaration para. 39 (2012), available at http://www.g20.utoronto.ca /2012/2012-0619-loscabos.pdf.

103 Overview, Fin. STABILITY BOARD, http://www.financialstabilityboard.org/about/over view.htm (last visited Feb. 20, 2014). 
is composed of the same countries as the G20, but also includes the Netherlands, Spain, Switzerland, several international organizations, ${ }^{104}$ and several international standard-setting bodies. ${ }^{105}$ The FSB has so far delivered six reports on the progress in implementing OTC derivative reforms, focusing in particular on the G20 commitments. ${ }^{106}$

The most recent interim report, delivered on September 2, 2013, ${ }^{107}$ reports progress on implementing the G20 framework. In the Executive Summary to the FSB Report, it notes that "[m]arket participants in general appear to be making good progress in their preparations for implementation of OTC derivatives market reforms," and also, however, that "regulatory uncertainty has held back the finalisation of preparations by some market participants." ${ }^{108}$ The report continues, however, noting that the G-20 countries are continuing to progress in their work:

The large share of cross-border activity in many OTC derivatives markets means that clarity in how jurisdictions' regulatory regimes interact is crucial for all stakeholders. Two major constructive steps forward have been taken: first, the announcement in July by the CFTC and the EC of their joint understandings; and subsequently, a multilateral set of understandings to improve the cross-border implementation of OTC derivatives reforms, announced in August by the Regulators Group. ${ }^{109}$

The FSB recommended that G20 countries should continue "to urge authorities to resolve regulatory conflicts, inconsistencies, duplication and gaps in order to provide certainty to stakeholders." ${ }^{110}$ Further, the FSB still voiced concerns about cross-border considerations noting that " $[\mathrm{u}]$ ncertainties about the treatment of cross-border activity (whether of market participants or of infrastructure) under various jurisdictions' regimes continue to be a concern for market participants as regulatory requirements take effect." 111

Canada, the Unites States' key neighbor to the north, is a G20 jurisdiction taking steps to comply with the G20 goals. Recently, Canada has "introduced legislation to Parliament . . . to allow for central clearing for over-the-counter derivatives contracts," 112 although observers noted that it "is not likely to be

104 These include the Bank for International Settlements, European Central Bank, European Commission, International Monetary Fund, Organisation for Economic Co-operation and Development, and the World Bank. Links to FSB Members, Fin. Stability Board, www .financialstabilityboard.org/members/links.htm (last visited Feb. 20, 2014).

105 Basel Committee on Banking Supervision; Committee on the Global Financial System; Committee on Payment and Settlement Systems; International Association of Insurance Supervisors; International Accounting Standards Board; and International Organization of Securities Commissions. Id.

106 The six reports are available at Publications - Progress Reports, Fin. STABility Board, http://www.financialstabilityboard.org/list/fsb_publications/tid_178/index.htm (last visited Feb. 20, 2014).

107 Fin. Stability Bd., OTC Derivatives Market Reforms: Sixth Progress Report on IMPLEMENTATION (2013), available at http://www.financialstabilityboard.org/publications /r_130902b.pdf.

$108 \mathrm{Id}$. at 1 .

109 Id. at 2.

$110 \mathrm{Id}$.

$111 \mathrm{Id}$. at 5.

112 Courtney Tower, Canada Govt Proposes Central Clearing for OTC Derivatives, MNI (Oct. 18, 2012, 5:29 PM), https://mninews.marketnews.com/content/canada-govt-proposes -central-clearing-otc-derivatives-0. 
passed into law quickly." ${ }^{13}$ Canada, however, has also been wary that the Dodd-Frank reforms could lead to unintended consequences and problems. ${ }^{114}$

On January 31, 2012, the CFTC and the SEC issued the Joint Report on International Swap Regulation (the "Joint Report"). ${ }^{115}$ Congress required the CFTC and the SEC to study the regulation of OTC derivatives across the United States, Asia, and Europe in hopes of identifying areas of potential regulatory arbitrage. ${ }^{116}$ The Joint Report consists of 153 pages of analysis. The Joint Report notes that "progress varies across jurisdictions in meeting the 2009 G-20 Leaders' commitments."117 The Joint Report further notes that " $[\mathrm{t}] \mathrm{he}$ G20 leaders have agreed to the OTC derivatives commitments, but it is still too early to determine precisely where there is alignment internationally and where there may be gaps or inconsistencies." 118

\section{Regulatory Arbitrage and Global OTC Derivative Markets}

From the beginning of the recent push to regulate OTC derivatives, regulators and policy makers have been cognizant that such regulation imposed a risk of creating regulatory arbitrage. Jonathan Macey, in his seminal article on regulatory competition provides a description of the condition: "[A]s technology has advanced and strong capital markets have developed in other countries, the phenomenon of "regulatory arbitrage" has become more prevalent. Regulatory arbitrage occurs when competitors locate their activities in those jurisdictions that offer the most attractive set of regulations." 119

Regulatory arbitrage, in this article, involves parties choosing to transact in (or moving business to) jurisdictions that are unregulated or lightly regulated in comparison to other jurisdictions. This could also be referred to or characterized as "jurisdictional arbitrage." 120

113 Id.

114 Jeremy Grant \& Bernard Simon, Canada Official Warns on OTC Clearing Reforms, FIN. Times (Sept. 20, 2011, 12:45 AM), www.ft.com/intl/cms/s/0/900e5c68-e30e-11e0-bb55 -00144feabdc0.html\#axzz2f07LYmY7.

115 Commodity Futures Trading Comm'n, U.S. Sec. and Exch. Comm'n, Joint Report on International Swap Regulation (2012) [hereinafter Joint Report], available at http://www.cftc.gov/ucm/groups/public/@ swaps/documents/file/dfstudy_isr_013112.pdf.

116 DFA Section 719(c) requires the Commissions jointly to conduct a study ("Study") and then to report to Congress ("Report") on how swaps and security-based swaps (collectively "Swaps", unless otherwise indicated) are regulated in the United States, Asia, and Europe and to identify areas of regulation that are similar and other areas of regulation that could be harmonized. Section 719(c) also calls for the Report to identify major dealers, exchanges, clearinghouses, clearing members, and regulators in each geographic area and to list the major contracts (including trading volumes, clearing volumes, and notional values), the methods for clearing swaps, and the systems used for setting margin in each geographic area.

Id. at 2 (footnote omitted).

117 Id. at 111.

118 Id.

119 Jonathan R. Macey, Regulatory Globalization as a Response to Regulatory Competition, 52 EмоRy L.J. 1353, 1362 (2003) (emphasis added).

120 See infra Part III.D for a discussion of regulatory arbitrage within the same jurisdiction. 


\section{A. Examples of Regulatory Arbitrage Outside of OTC Derivatives}

There are numerous examples of regulatory arbitrage that have been studied vigorously. The most famous is probably the competition between jurisdictions for incorporating businesses in order to capture franchise fees and other benefits. ${ }^{121}$ A similar race to the bottom is emerging in Europe as well with respect to the same incorporation issue. ${ }^{122}$

An analogous situation to the current race to regulate OTC derivatives was the enactment of the Sarbanes-Oxley regulatory regime in reaction to the various corporate scandals that occurred in the United States in the early 2000s. ${ }^{123}$ As the United States imposed penalties for corporate malfeasance on the executives of publicly traded companies, there was concern that foreign companies would avoid listing in the United States. Although the evidence is somewhat mixed, it appears that Sarbanes-Oxley had a negative effect on companies listing in the United States. ${ }^{124}$ There is also evidence that regulatory costs of

121 Lucian Arye Bebchuk, Federalism and the Corporation: The Desirable Limits on State Competition in Corporate Law, 105 HARv. L. Rev. 1437, 1438 (1992) (arguing that there is a race to the bottom with respect to certain issues); Lucian Arye Bebchuk \& Allen Ferrell, Federalism and Corporate Law: The Race to Protect Managers from Takeovers, 99 Colum. L. Rev. 1168, 1170 (1999); William W. Bratton, Corporate Law's Race to Nowhere in Particular, 44 U. Toronto L.J. 401, 401 (1994); William L. Cary, Federalism and Corporate Law: Reflections Upon Delaware, 83 YALE L.J. 663, 663 (1974); Ralph K. Winter Jr., State Law, Shareholder Protection, and the Theory of the Corporation, 6 J. Legal STUD. 251, 251 (1977); Ralph K. Winter, The "Race for the Top" Revisited: A Comment on Eisenberg, 89 Colum. L. Rev. 1526, 1526 (1989). For revisionist views denying the relevance of interstate competition, see Marcel Kahan \& Ehud Kamar, The Myth of State Competition in Corporate Law, 55 Stan. L. Rev. 679 (2002); Mark J. Roe, Delaware's Competition, 117 Harv. L. Rev. 588, 590 (2003); Mark J. Roe, Delaware's Politics, 118 Harv. L. Rev. 2491, 2493 (2005).

122 See John Armour, Who Should Make Corporate Law? EC Legislation versus Regulatory Competition, 58 Current Legal Probs. 369, 386 n.67-68 (2005) (providing data on so called "GmbH limited," i.e. German businesses incorporated as English private limited companies).

123 See Larry Bumgardner, Reforming Corporate America, 6 Graziadio Bus. Rev., no. 1 2003, available at http://gbr.pepperdine.edu/2010/08/reforming-corporate-america/.

124 Brian J. Bushee \& Christian Leuz, Economic Consequences of SEC Disclosure Regulation: Evidence from the OTC Bulletin Board, 39 J. AccT. \& Econ. 233, 234 (2005); Dobrina Georgieva, Does Sarbanes-Oxley Act Chase Away Foreign Firms? Evidence From ADR Terminations, 14 Allied ACAD. InT'L Conf. 16, 16-17 (2009); Peter Hostak et al., An Examination of the Impact of the Sarbanes-Oxley Act on the Attractiveness of U.S. Capital Markets for Foreign Firms, 18 Rev. Aсcт. Stud. 522, 524 (2013), available at http://ssrn .com/abstract=956020; Christian Leuz et al., Why Do Firms Go Dark? Causes and Economic Consequences of Voluntary SEC Deregistrations 4 (European Corp. Governance Inst., Working Paper No. 155, 2008), available at http://papers.ssrn.com/sol3/papers.cfm?abstract $i d=592421$; Suraj Srinivasan \& Joseph D. Piotroski, Regulation and Bonding: The Sarbanes-Oxley Act and the Flow of International Listings 1 (Rock Ctr. for Corp. Governance, Working Paper No. 11, 2008), available at http://ssrn.com/abstract=956987; Luigi Zingales, Is the U.S. Capital Market Losing its Competitive Edge? 3 (European Corp. Governance Inst., Working Paper No. 192, 2007), available at http://papers.ssrn.com/sol3/papers .cfm?abstract_id=1028701. But see Craig Doidge et al., Has New York Become Less Competitive in Global Markets? Evaluating Foreign Listing Choices over Time 43-44 (European Corp. Governance Inst., Working Paper No. 173, 2007), available at http://ssrn.com/abstract _id=982193. 
Sarbanes-Oxley have depressed venture capital in the United States. ${ }^{125}$ In other words, in spite of the depth, liquidity, and safety of US capital markets, foreign companies chose not to list their securities in the United States due to regulation that was more stringent than in other jurisdictions, such as England or Singapore.

Hedge funds have also made decisions to organize or locate in less-regulated jurisdictions to take advantage of, for instance, minimizing tax burdens or avoiding securities law regulation:

Hedge funds can be domiciled in onshore or offshore locations. Close to a half of the number of hedge funds in June 2011 were registered in offshore locations. The Cayman Islands was the most popular registration location and accounted for 34 [percent] of the number of global hedge funds, down on its 39 [percent] share two years earlier. It was followed by the US 24 [percent], Luxembourg 10 [percent], Ireland 7 [percent], British Virgin Islands 6 [percent] and Bermuda 3 [percent]. ${ }^{126}$

With respect to where they actually trade and transact business, however, one commentator noted that " $[\mathrm{t}]$ he data examined offer little or no support for the view that hedge fund managers pursuing riskier strategies or strategies with potentially more agency problems systematically select jurisdictions with less stringent regulation."127

The recent explosion of offshore internet gaming may also provide lessons about the difficulty of regulating cross-border OTC derivative trading. It is estimated that internet gaming is a $\$ 12$ billion industry, with over 2,300 sites. ${ }^{128}$ In reaction to concerns about the industry, ${ }^{129}$ Congress enacted the Unlawful Internet Gambling Enforcement Act of 2006. ${ }^{130}$ This effort, however, has resulted in a casebook example of regulatory arbitrage. "In legislating to excise the online gambling industry from its territory, it has effectively driven the industry offshore to states that will license it, such as the UK." ${ }^{131}$ In addition,

125 Dale A. Oesterle, The High Cost of IPOs Depresses Venture Capital in the United States, 1 Entrepreneurial Bus. L.J. 369, 369 (2007)., available at http://ssrn.com /abstract $=923572$.

126 TheCityUK, Financial Markets Series: Hedge Funds 4 (2012), available at http:// www.thecityuk.com/research/our-work/reports-list/hedge-funds-2012/.

127 Douglas J. Cumming \& Sofia Johan, Hedge Fund Forum Shopping, 10 U. Penn J. Bus. \& EMP. L. 783, 783 (2008), available at http://ssrn.com/abstract=1122309.

128 Bunnam Srephichet, Pirates of the Caribbean: Offshore Internet Gambling Sites Cursed by the Unlawful Internet Gambling Enforcement Act, 30 Hastings Comm. \& ENT. L.J. 139, 140 (2007).

129 "[G]overnments have longstanding concerns with the operation of gambling enterprises. The possibility of funding criminal (and perhaps terrorist) enterprises, expanding social costs from pathological or problem gambling, protecting minors, and other normative judgments have all contributed toward government-imposed limits on gambling . . . ." Edward A. Morse, The Internet Gambling Conundrum: Extraterritorial Impacts of U.S. Laws on Internet Businesses, 23 COMPUTER L. \& SeCurity ReP. 529, 529 (2007).

130 Unlawful Internet Gambling Enforcement Act of 2006, Pub. L. No. 109-347, § 801, 120 Stat. 1952 (codified at 31 U.S.C. $\$ 5301$ (2012)). For a discussion of the Act, see Brant M. Leonard, Highlighting the Drawbacks of the UIGEA: Proposed Rules Reveal Heavy Burdens, 57 Drake L. Rev. 515 (2009).

131 Betsi Beem \& John Mikler, National Regulations for a Borderless Industry: US Versus UK Approaches to Online Gambling, 30 POL'y \& Soc'y 161, 171 (2011). 
there is evidence that US investment capital has followed the movement of the industry into other, less-regulated jurisdictions. ${ }^{132}$

\section{B. Regulatory Arbitrage and OTC Derivative Reforms}

From the beginning of the recent effort to regulate global derivative markets, there has been concern that regulatory arbitrage would occur. Faced with stiff new regulatory requirements in disparate jurisdictions, policymakers and regulators feared that participants would move their OTC derivative trading activity to less-regulated environments. The risk of regulatory arbitrage occurring with OTC derivatives is particularly strong due to a variety of factors.

\section{Regulatory Gaps Between US Regulation, G20, and Non-G20 Regulation}

Regulatory arbitrage will only exist to the extent that there is a difference between the level of US regulation and that of other jurisdictions. As will be explained below, it is inevitable that there will be substantive and important differences between the level of US regulation and that of the G20 in particular, and other jurisdictions in general. All indications signal that US regulation will be at a higher level than that of competing jurisdictions. Foreign regulators have noted that, based on the current CFTC rules and proposed guidance, there is the possibility that "[a]ffected non-US persons will have to comply with two sets of regulations, which may be overlapping and conflicting, imposed by the US and individual non-US regimes. This is compounded by the lack of clarity and specificity in a number of areas of the Proposed Guidance."133

To the extent that the United States is unable to harmonize its regulations with those of competing jurisdictions, participants will weigh the costs of US regulation against the benefits of trading in a jurisdiction with a lower level of regulation. As will be discussed below, the United States will attempt to ensure that non-US persons that trade in the United States will trade outside the United States in compliance with either US regulation or comparable regulation in a competing jurisdiction.

\section{Legal Uncertainty and Complexity}

Dodd-Frank set an aggressive time line and agenda for reforming the trading of OTC derivatives. As opposed to adopting an incremental approach to reform, Congress has attempted to completely remake the OTC derivative market in a relatively short period of time. Already, deadlines have been extended several times and the difficulties stem from a failure to finalize rules on a timely basis and the necessity to develop new technologies, software, and processes to implement trading under new statutory and regulatory guide-

132 Morse, supra note 129, at 536.

133 Letter from Belinda Gibson, Deputy Chairman, Australian Sec. and Inv. Comm'n, et al., to Gary Gensler, Chairman, Commodity Futures Trading Comm'n (Aug. 27, 2012) [hereinafter Foreign Regulators' Letter] (regarding CFTC Proposed Guidance on Cross-Border Application of Certain Swap Provisions of Commodity Exchange Act), available at https:// coursewebs.law.columbia.edu/coursewebs/cw_13S_LAW_L8221_001.nsf/0f66a77852c3921 f852571c100169cb9/28DABB939DFBDAA985257B0100780E09/\$FILE/APac+Regulators +Comment+Letter.pdf?OpenElement. 
lines. ${ }^{134}$ Swap dealers and their customers are left guessing as to when and how they are to comply with the avalanche of new rules and regulations. This legal uncertainty and complexity provides a key motivation for participants to trade in markets where such uncertainty does not exist.

Included in US policy makers' agenda are reforms such as mandatory exchange trading and clearing of OTC derivatives (with certain key exceptions), ${ }^{135}$ position limits, ${ }^{136}$ providing initial and variation margin for uncleared swaps, ${ }^{137}$ capital requirements on dealers, ${ }^{138}$ and new business conduct standards. ${ }^{139}$

The amount and complexity of rulemaking that has been required of the CFTC and the SEC is both breathtaking and inconceivable. The United States has been engaged in a furious rulemaking effort that is still incomplete. The difficulty in drafting all of the rules and regulations to implement the DoddFrank statutory requirements appears to have been poorly understood by policymakers and regulators. Normally the CFTC issues three or four rules a year, now the CFTC has, 'in order to complete the 'Herculean task' of finalizing more than [fifty] rules, ... established more than [thirty] multi-disciplinary, rule-writing teams." 140 Their task has also been compounded by congressional efforts to reduce their funding. ${ }^{141}$

The CFTC identified thirty-eight areas in which it needed to promulgate regulations to interpret particular provisions of Dodd-Frank dealing with OTC derivatives. ${ }^{142}$ The individual thirty-eight areas are broken into eight categories: comprehensive regulation of swap dealers and major swap participants; clearing; trading; data; particular products; enforcement; position limits; and other titles. ${ }^{143}$

As of October 11, 2012, the CFTC has issued sixty-eight proposed rules, four advanced notices of proposed rulemaking, and six proposed exemptive orders. ${ }^{144}$ Of those rules and orders, the CFTC "has now finalized [sixty-one]

134 For a discussion of the practicalities of implementing clearing, see Christian Johnson, The Enigma of Clearing Buy Side OTC Derivatives, 29 Futures \& Derivatives L. Rep. 1 (2009), available at http://ssrn.com/abstract $=1544017$.

135 Dodd-Frank Act, Pub. L. No. 111-203, § 723, 124 Stat. 1675 (2010) (codified as amended at 7 U.S.C. $§ 2(\mathrm{~h})(2012)$ ).

136 Dodd-Frank Act Position Limits $§ 737$ (codified as amended at 7 U.S.C. § 6a(a) (2012)).

137 Dodd-Frank Act Unclear Swaps § 731 (codified as amended at 7 U.S.C. § 6s(e) (2012)).

1387 U.S.C. $\S 6 \mathrm{~s}(\mathrm{e})(2012)$.

139 Dodd-Frank Act Unclear Swaps § 731; Dodd-Frank Record Keeping § 764 (codified as amended 15 U.S.C. § 78o-8(f) (2012)).

140 CFTC's O'Malia Says 'High Frequency Regulation' Causing Angst, Automated TRADER (May 31, 2012), http://www.automatedtrader.net/news/Algorithmic\%20Trading\% 20News/126922/cftcs-omalia-says-high-frequency-regulation-causing-angst.

141 Charles Riley, Broken Budget Process Hurts Wall Street Reform, CNNMoney (February 10, 2012, 5:07 AM), http://money.cnn.com/2012/02/10/news/economy/cftc_sec_budget /index.htm.

142 CFTC Rulemakings, U.S. Commodity Futures Trading Commission, http://www.cftc .gov/LawRegulation/DoddFrankAct/Rulemakings/index.htm (last visited Feb. 21, 2014).

143 Id.

144 Dodd-Frank Proposed Rules and Advanced Notices, U.S. Commodity Futures TradING Commission, http://cftc.gov/LawRegulation/DoddFrankAct/Dodd-FrankProposedRules /index.htm (last visited Feb. 21, 2014). 
rules, exemptive orders and guidance actions and [three] other actions."145 It has published two separate "question and answers" and published three staff letters. ${ }^{146}$ Together, the CFTC has published in the Federal Register (three columns per page) over 4,200 pages of rules and regulations (including CFTC commentary and explanation) interpreting the Dodd-Frank OTC derivative reform provisions. All of this information literally needs to be digested by regulators and participants in the OTC derivative markets.

As part of the rule making process, the CFTC has made a great effort to include comment and input from the public. To date, it has held thirty public meetings since October 1, 2010, and has held twenty-one public roundtable discussions. $^{147}$

In addition to the efforts of the CFTC, the SEC has also been charged with issuing rules and regulations on "security-based swaps." 148 To date, the SEC has made not nearly the progress as the CFTC in adopting appropriate rules. ${ }^{149}$

Adding complexity is the fact that many of these rules require the CFTC to issue them jointly with the SEC, demanding interagency cooperation and compromise. For example, the CFTC and SEC issued further definitions of "Swap," "Security-Based Swap" and "Security-Based Swap Agreement," "Mixed Swaps," and "Security-Based Swap Agreement Recordkeeping," effective on July $23,2012 .{ }^{150}$

The energy required to digest and understand all of this detail and complexity is mind-boggling and suggests that the CFTC may ultimately have entered into an exercise of futility, creating so many requirements and rules that assessing compliance may become impossible. This onslaught of detailed rules and regulations is difficult enough for US swap dealers, complete with legions of lawyers, compliance officers, and executives, to navigate. It becomes a nightmare for their US customers to understand. One can only imagine how foreign swap dealers and foreign customers must view the Dodd-Frank regulatory reforms.

145 Dodd-Frank Final Rules, Final Guidance, Final Exemptive Orders, and Other Final Actions, U.S. Commodity Futures Trading Commission, http://cftc.gov/LawRegulation /DoddFrankAct/Dodd-FrankFinalRules/index.htm (last visited Feb. 21, 2014).

146 Dodd-Frank Staff Guidance, Questions and Answers, Memoranda, and Letters, U.S. Commodity Futures Trading Commission, http://cftc.gov/LawRegulation/DoddFrankAct /GuidanceQandA/index.htm (last visited Feb. 21, 2014).

147 Public Meetings and Roundtables, U.S. Commodity Futures Trading Commission, http://cftc.gov/LawRegulation/DoddFrankAct/Dodd-FrankPublicEvents/index.htm (last visited Feb. 21, 2014).

148 See Derivatives, U.S. SeC. \& Exchange Commission, http://www.sec.gov/spotlight /dodd-frank/derivatives.shtml (last visited Feb. 21, 2014). Although the SEC was given regulatory authority over "security-based swaps," they have largely been absent in the debate, leaving the CFTC to do the majority of the heavy lifting with the public.

149 SEC Interim Final Temporary Rules, U.S. Sec. \& Exchange Commission, http://www .sec.gov/rules/interim-final-temp.shtml (last visited Feb. 21, 2014); SEC Proposed Rules, U.S. Sec. \& Exchange Commission, http://www.sec.gov/rules/proposed.shtml (last visited Feb. 4, 2014); SEC Final Rules, U.S. Sec. \& Exchange Commission, http://www.sec.gov /rules/final/finalarchive/finalarchive2012.shtml (last visited Feb. 21, 2014).

150 Further Definition of "Swap Dealer," "Security-Based Swap Dealer," "Major Swap Participant," "Major Security-Based Swap Participant," and "Eligible Contract Participant," 77 Fed. Reg. 30,596, 30,596 (May 23, 2012) (to be codified at 17 C.F.R. pt. 1). 
The time-tables for required compliance with these rules are byzantine, arbitrary, and almost incomprehensible. The CFTC's approach to handling deadlines that cannot be reached has been problematic, with foreign regulators currently pressuring the CFTC "to avoid rushing through proposals on the trading of swaps among US and foreign [trading] firms." 151

Dodd-Frank originally provided that the provisions were to become effective on July $16,2011 .^{152}$ Because it was unable to finalize the rules necessary by the original deadline, the CFTC extended the deadline to the earlier effective date of certain key final rules or December 31, 2011, by issuing a temporary exemptive relief order on July 14, 2011. ${ }^{153}$ On December 19, 2011, the CFTC amended the July 14, 2011 order and extended the effective date until July 16, 2012, again because the CFTC was unable to finalize certain key rules. ${ }^{154}$ On July 3, 2012, the CFTC again extended the effective date until December 31, 2012. ${ }^{155}$ Although many of the key rules have now been finalized, the CFTC now faces the issue that many of the participants in the OTC derivative market may be operationally and functionally unable to comply with the Dodd-Frank derivative mandates.

The CFTC's approach to extending deadlines has been mystifying. The only explanation is that the CFTC is reluctant to take its foot off the pedal in the race to regulatory reform. The CFTC perhaps may be concerned that if pressure is taken off the derivative reform schedule, it risks key regulatory reforms being co-opted by aggressive lobbyists and legislative opponents of the reforms.

It is mystifying, for example, when it was self-evident that the regulatory reforms were not going to be achieved by July 16, 2011, that the CFTC did not act before July 14, 2011, to finally and formally extend the compliance deadlines. By unnecessarily delaying the unavoidable conclusion that the deadlines needed to be extended, market participants were forced to do everything in their power to comply with unattainable statutory requirements by an unrealistic and artificial deadline. The end result was confusion, uncertainty, and wasted effort.

The problem with the complexity of the rules and regulations is not necessarily that they were not thoughtfully and carefully developed, but that the sheer quantity and complexity makes digesting these rules, especially in the

151 Vladimir Guevarra, CFTC Under Fire Abroad on Swaps: Officials Balk at Requirement That Foreign Firms Register Under U.S. Rules, WaLL ST. J., http://online.wsj.com/article /SB10000872396390444734804578064501772464428.html (last updated Oct. 18, 2012, $1: 14$ PM).

152 Dodd-Frank Act $§ 754$ (codified as amended at 7 U.S.C. § 7a note (2012)). For a discussion of the deadlines, see CFTC Adopts Second Amended July 14 Exemptive Relief Order Pertaining to the Effective Date for Swap Regulation, SutherLand (July 6, 2012), http:// www.sutherland.com/NewsCommentary/Legal-Alerts/93066/Legal-Alert-CFTC-Adopts -Second-Amended-July-14-Exemptive-Relief-Order-Pertaining-to-the-Effective-Date-for -Swap-Regulation.

153 Effective Date for Swap Regulation, 76 Fed. Reg. 42,508, 42,510 (July 19, 2011).

154 Letter from Ananda Radhakrishnan, Dir., Div. of Clearing and Risk, et al., on Staff NoAction Relief 3 (Dec. 19, 2011), available at http://cftc.gov./ucm/groups/public/@1rlettergen eral/documents/letter/11-09.pdf.

155 Second Amendment to July 14, 2011 Order for Swap Regulation, 77 Fed. Reg. 41,260 (July 13, 2012). 
narrow time frame given, a Sisyphean task of futility for many participants. The efforts to follow, digest, and comply with what appears to be an endless issuance of new rules and regulations, all of which require compliance, leaves many to believe that they will never master the new OTC derivative reforms.

\section{Costs of Conforming}

Given the wholesale reforms of the OTC derivative market being enacted and contemplated, there are tremendous cost motivations to avoid trading in the more highly regulated jurisdictions. Although the total costs of these reforms has not been completely reconciled, the costs for participants to implement these reforms will be high.

The increased cost stems from the reforms requiring participants in the OTC derivatives industry to completely remake and restructure their business practices and their infrastructure, ${ }^{156}$ in order to accommodate such reforms as mandatory exchange trading and clearing of OTC derivatives (with certain key exceptions), position limits, providing initial and variation margin for uncleared swaps, capital requirements on dealers, and new business conduct standards. ${ }^{157}$ Dealers and end users would need to put into place new products, systems, procedures, back offices, and processes in order to implement these reforms. ${ }^{158}$ Commentators have noted that "one thing is clear: this is the biggest phase of turbulence that the derivatives market has gone through. You are taking 80 per cent of the market and changing the way it trades."159

There is no doubt that trading OTC derivatives as currently regulated is a profitable business, reaping an estimated $\$ 50$ billion in annual revenues for the "leading global dealer banks." 160 The reforms, however, promise to be expensive. It is difficult to determine the bottom line effect on swap dealers' profitability in the United States; however, there have been estimates of the cost of compliance. Although the report could be viewed as self-serving because it was prepared by an industry leader, the Europe Equity Research Group of JPMorgan analyzed the effect of the OTC derivative reforms on seven global swap dealers that included Credit Suisse, UBS, Deutsche Bank, Goldman Sachs, Morgan Stanley, BNP, and Société Générale in 2009 (the "JPM Report"). ${ }^{161}$

156 See Stephen Foley \& Michael Mackenzie, Swaps Trades on Brink of Tough New Regime, Fin. Times (Oct. 17, 2012, 3:52 PM), http://www.ft.com/intl/cms/s/0/0087823c -123c-11e2-868d-00144feabdc0.html\#axzz2scDN8LpJ.

157 See supra text accompanying notes 135-39.

158 For a discussion that similar considerations exist for centralized clearing and reporting, see Gavin Blair, Market Split Over HK OTC Derivative Proposals, Trade (July 25, 2012), http://www.thetradenews.com/news/Regions/Asia/Market_split_over_HK_OTC_derivatives _proposals.aspx?terms=market+split+over+hk+otc (Dr. Alex Frino acknowledged, "[t]hey are so heterogeneous that working out the risks for each one individually will be so difficult that the economies of scale for clearing houses won't work, it will be very expensive. That would impose costs on OTC derivatives.").

159 Foley \& Mackenzie, supra note 156.

160 Michael Mackenzie \& Tracy Alloway, Swaps Profits Threatened by Dodd-Frank, FIN. TIMES, http://www.ft.com/intl/cms/s/0/dd5c64ec-ebc3-11e1-985a-00144feab49a.html\#axzz2 scDN8LpJ (last updated Aug. 22, 2012, 10:34 PM).

161 Although somewhat dated, JPMorgan Chase prepared a report on the cost on dealers of anticipated derivative regulation. J.P.Morgan, Global Investment BanKs: New OTC Derivatives Regulation (2009). The report estimates that these reforms may "lower [an 
The JPM Report's summary concluded the following:

Regulatory changes in OTC derivatives and market risk requirements lower [investment bank] returns by decreasing [investment banks] net income -13 [percent] and increasing [investment banks'] RWA [risk weighted assets] by 21 [percent] on average in our estimates:

-13 [percent] negative impact on [investment bank] net profits on average: the biggest impact comes from OTC post trade transparency with -6 [percent] impact, followed by position limits in commodities ( -3 [percent] on earnings), and moving CDS to exchange trading ( -2 [percent])....

21 [percent] increase in [investment banks'] RWAs [risk weighted assets] on average: The main impact from regulatory changes is the higher capital requirements. ${ }^{162}$

Stock analysts at Standard \& Poor's “expect an annual drop in revenues for large dealers of between $\$ 4 \mathrm{bn}$ and $\$ 4.5 \mathrm{bn}$ once rules that include reporting requirements, the establishment of swap execution facilities (SEFs), in effect electronic exchanges, and mandatory central clearing of OTC swaps are fully implemented."163

Technology and operational costs alone have been extraordinarily expensive: "A study of Dodd-Frank's impact on the buy and sell sides finds that while sell-side firms have spent over a \$1 billion [sic] on operational and IT changes, confusion reigns on the buy side." 164 Other analysts estimate that "[f]inancial firms will spend an estimated $\$ 6.7$ billion over a three-year period to address the technological and operational changes required to comply with new US and European regulations affecting the growing swaps market."165 These costs include developing new software programs and platforms, computer and telecommunications equipment, and legions of programmers and IT personnel.

In addition to the direct costs of complying with US regulation by US persons, subjecting non-US persons to Dodd-Frank regulation also imposes both market costs and direct costs to participants:

Potential market disruption or fragmentation, with consequently increased risks to systemic stability and market liquidity in our markets, may arise as market participants may have to change their business models or even withdraw from certain businesses, all within a relatively short period of time. The impact from any resulting (likely significant) increase in compliance costs and the potential reduction in liquidity of OTC derivatives markets should not be under-estimated. ${ }^{166}$

\section{Collateral Cost and Scarcity}

One of the key drivers of regulatory arbitrage in this area will be the growing and increased role of collateral (i.e., initial margin and variation margin).

investment bank's] returns by decreasing [investment bank] net income -13 [percent]." Id. at 3 .

162 Id.

163 Mackenzie \& Alloway, supra note 160.

164 Ivy Schmerken, Dodd Frank Confusion Reigns on Buy Side - Study, Wall St. \& Tech. (Mar. 12, 2012), http://www.wallstreetandtech.com/regulatory-compliance/dodd-frank-confu sion-reigns-on-buy-side/232602411.

165 Chris Kentouris, Tackling Swaps Regs: Whopping \$6.7 Billion Pricetag, ISS-MAG (Jan. 10, 2012), http://www.iss-mag.com/news/tackling-swaps-regs-whopping-dollar-6.7-billion.

166 Foreign Regulators' Letter, supra note 132, at 2. 
Regulators believe that a key component to reducing the risk of OTC derivatives is to require drastically increased use of collateral. ${ }^{167}$ Such collateral requirements may drive participants out of the US OTC derivative markets to search for markets where the mandated amount of collateral is not so high.

Dodd-Frank and the G20 commitments require OTC derivatives transactions to be collateralized, regardless of whether they are cleared or uncleared. Estimates of the global demand for additional collateral run from the hundreds of billions to trillions, putting tremendous pressure on the supply of eligible collateral. ${ }^{168}$

In an effort to agree to an appropriate amount of collateral for uncleared trading, the Basel Committee on Banking Supervision (the "CBS") and International Organization of Securities Commissions (IOSCO) released a consultative paper entitled "Margin Requirements for Non-Centrally-Cleared Derivatives" (the "Margin Requirements Paper"). ${ }^{169}$ A similar working paper was released by the BIS on cleared derivatives and collateral. ${ }^{170}$ Although the key focus of the United States and the other G20 jurisdictions has been to move the market toward central clearing of OTC derivatives, many of the traditional OTC derivative products that are currently traded on a bilateral basis may not be clearable, with regulators, based on the G20 Pittsburgh and Cannes commitments, taking the position that uncleared trades should still be subject to similar regulatory margin requirements as the cleared OTC derivatives. ${ }^{171}$

Critics have argued that the Margin Requirements Paper's recommendations will impose serious costs on bilateral trading and markets. ${ }^{172}$ First, the ISDA estimates that requiring "a universal two-way exchange of [initial margin] between financial firms and systemically important non-financial firms . . . [is] estimated to be in the region of US\$15.7 trillion to US\$29.9 trillion for [initial margin] only." 173 Second, the ISDA estimates that meeting the margin requirements will substantially increase the cost "of providing a plain vanilla interest rate OTC derivative." ${ }^{174}$ Third, the margin requirements would "lead to

167 Aaron Lucchetti, Collateral Rules Criticized, Wall ST. J. (July 25, 2011), http://online .wsj.com/article/SB10001424053111904772304576466360844147694.html.

168 See id.

169 Basel Comm. on Banking Supervision, Bd. of the Int'l Org. of Sec. Comm'ns, Consultative Document: Margin Requirements for Non-Centrally-Cleared DerivATIVES (2012), available at http://www.bis.org/publ/bcbs226.pdf.

170 Daniel Heller \& Nicholas Vause, Collateral Requirements for Mandatory Central Clearing of Over-the-Counter Derivatives (Bank for Int'l Settlements, Working Paper No. 373, 2012), available at http://www.bis.org/publ/work373.pdf.

171 See infra text accompanying notes 351-61.

172 See Comments Received on the Consultative Document "Margin Requirements for NonCentrally Cleared Derivatives", Bank InT'L SETtLements, http://www.bis.org/publ /bcbs226/comments.htm (last visited Feb. 23, 2014) [hereinafter Margin Requirements].

${ }^{173}$ Letter from George Handjinicolaou, Deputy CEO and Head of ISDA Eur., Middle East and Afr., to Secretariat, Basel Comm. on Banking Supervision, Bank for Int'l Settlements, et al., on Consultative Document: "Margin Requirements for Non-Centrally-Cleared Derivatives" 2 (Sept. 28, 2012), http://www.bis.org/publ/bcbs226/isda.pdf [hereinafter ISDA Response]. For a discussion of the ISDA calculations, see Peter Eavis, Behind an Estimated $\$ 30$ Trillion Drain on Banks, a Lot of Hypotheticals, N.Y. Times, Oct. 30, 2012, at B5, available at http://dealbook.nytimes.com/2012/10/29/behind-estimated-30-trillion-drain-a -lot-of-hypothetical-assumptions/?_r=0.

174 ISDA Response, supra note 172, at 7. 
a very high percentage of the collateral pool currently available in the market having to be pledged as [initial margin]." ${ }^{175}$ Others believe that the consequences, however, may be much less severe. ${ }^{176}$

As collateral becomes more scarce and expensive, counterparties will look to jurisdictions with more liberal collateral rules. Nonconforming jurisdictions that require less collateral than conforming jurisdictions will become more desirable from a collateral perspective, driving trading into these jurisdictions.

Under the CFTC rules, uncleared bilateral OTC derivatives trades will need to be collateralized by both parties with initial margin and the out-of-themoney party will need to post variation margin. ${ }^{177}$ As more and more OTC derivatives trades (either cleared or bilateral) become subject to both initial margin and variation margin requirements, ${ }^{178}$ it will become more and more expensive to pledge collateral. ${ }^{179}$ Securities that are clearinghouse eligible will become more and more difficult to acquire. In addition, many non-financial institutions do not hold large amounts of cash or clearinghouse-eligible securities.

If jurisdictions establish less rigorous margin and collateral rules than those in the United States for their home institutions, this could lead to competitive problems. " "If those margin rules for foreign operations are maintained and Europeans and other foreign jurisdictions do not match it, that would be a significant competitive disadvantage,' Fed Chairman Ben S. Bernanke testified to Congress on July 21."180 Chairman Gensler has also noted that "it is essential that we align these requirements globally, particularly between the major market jurisdictions."181

175 Id.

176 Helen Bartholomew, JPM Calms Collateral Fears, ReuTERs (Oct. 8, 2012), http:// in.reuters.com/article/2012/10/08/derivatives-collateral-idINL6E8L8KCC20121008 ("On its calculations, JPM analysts believe the additional demand for collateral will be limited as the majority of the OTC derivatives markets already use collateral agreements.").

177 Margin Requirements for Uncleared Swaps for Swap Dealers and Major Swap Participants, 76 Fed. Reg. 23,732, 23,735 (Apr. 28, 2011) (codified at 17 C.F.R. pt. 23).

178 Anouk Levels \& Jeannette Capel, Is Collateral Becoming Scarce? Evidence for the Euro Area, 10 De Nederlandsche Bank Occasional Stud., no. 1, 2012, at 3, 3, available at http://www.dnb.nl/binaries/DNB_OS_1001_WEB_tcm46-268455.pdf (“On the money market more transactions are now secured instead of unsecured and in OTC derivatives markets CCP clearing for standardized contracts becomes mandatory, raising collateral needs for market participants.”); New OTC Regulation Drives Collateral Scarcity for the $\$ 700$ Trillion Derivatives Market, CinNOBER (July 3, 2012), http://www.cinnober.com/sites/cinnober.com /files/news/120703enna_New_OTC_regulation_drives_collateral_scarcity.pdf.

179 Regulatory Reform and Collateral Management: The Impact on Major Participants in the OTC Derivatives Markets, J.P. Morgan Thought, Winter 2012, at 4, 5-7, available at https://www.jpmorgan.com/cm/BlobServer/Regulatory_Reform_and_Collateral_Managment pdf.pdf?blobkey=id\&blobwhere=1320534213352\&blobheader=application/pdf\&blobheader name $1=$ Cache-Control \&blobheadervalue $1=$ private $\&$ blobcol=urldata $\&$ blobtable $=$ Mungo Blobs.

180 Silla Brush, Goldman Sachs Among Banks Fighting to Exempt Half of Swaps Books, Bloomberg (Jan. 30, 2012, 9:01 PM), http://www.bloomberg.com/news/2012-01-30/gold man-sachs-among-banks-lobbying-to-exempt-half-of-swaps-from-dodd-frank.html.

181 Gary Gensler, Chairman, U.S. Commodity Futures Trading Comm'n, Remarks on Derivatives and the Cross-Border Application of Dodd-Frank Swap Market Reforms at the Institute of International Bankers' Membership Luncheon (June 14, 2012), available at http ://www.cftc.gov/PressRoom/SpeechesTestimony/opagensler-116. 
An additional issue is that the margining requirements for non-cleared OTC derivatives may be more expensive than clearing derivatives. "OTC derivatives trades that are not centrally cleared are likely to cost more than cleared transactions, due to pricing by bank counterparties, argues BNY Mellon." 182 One reason for this is that the initial margin may be greater for noncleared trades than for cleared trades. One factor in determining the amount of initial margin is the time that is required to terminate an open trade that has gone into default. It is generally assumed that uncleared trades will take longer to terminate, therefore requiring more initial margin.

\section{5. "Credit" versus "Collateral" Business Models}

The key reforms of requiring collateral are illustrative of the differences between the pre-reform exchange traded derivative industry and the OTC derivative industry. The exchange-trading environment has always been "credit quality" blind to a certain extent, requiring all participants to fully collateralize their positions. This is quite different from the business model that has existed since the 1980 s in the OTC derivative industry.

In the OTC derivative industry, parties have historically been willing to grant unsecured credit to credit-worthy counterparties. Most of this stems from banks, which customarily grant unsecured credit in certain situations and which were many of the initial dealers when the OTC derivative industry first developed. ${ }^{183}$ In contrast to the exchange-traded world, documentation frequently contained key credit provisions, such as cross-default provisions that were similar to the lending documentation that had been used for years. ${ }^{184}$

It is certainly probable that participants in nonconforming jurisdictions will be willing to continue the business model of granting unsecured credit (or at the minimum lesser collateral requirements) to their counterparties in those jurisdictions on the same basis as they are doing now. ${ }^{185}$ Credit-worthy counterparties will most probably be welcomed to trade with dealers in those nonconforming jurisdictions, similar to what currently occurs.

\section{Regulatory Arbitrage Occurring with OTC Derivatives in the Past}

It is not difficult to believe that regulatory arbitrage will occur in the future if one understands that regulatory arbitrage has been part of the market since the beginning. The classic example of regulatory arbitrage in the OTC

182 Georgina Lee, Sovereigns Urged to Clear OTC Trades, AsianInvestor (July 18, 2012), http://www.asianinvestor.net/News/308952,sovereigns-urged-to-clear-otc-trades.aspx

("Asian sovereigns might be better off centrally clearing over-the-counter derivatives trades regardless of statutory requirements, because the higher pricing charged on non-cleared, bilateral trades by bank counterparties is likely to outweigh clearing costs.").

183 Citibank, Bankers Trust, and JPMorgan Chase were all pioneers in the industry, as well as investment banks such as Solomon Brothers, Goldman Sachs and Bankers Trust. Many of the foreign dealers were also banking institutions such as UBS and Deutsche Bank, among others.

184 For a discussion of collateral documentation, see Paul C. Harding \& Christian A. Johnson, Mastering the ISDA Collateral Documents (2d ed. 2012).

185 Although there is clearly a trend to require collateral in the bilateral OTC derivative market currently, the collateral requirements are much less rigorous than that anticipated by Dodd-Frank mandates. 
derivative area concerns swap dealers' insistence on trading only with counterparties organized in jurisdictions with creditor-friendly insolvency regimes with respect to OTC derivatives.

A key concern of industry participants from the beginning has been the treatment of OTC derivative contracts in insolvency. Swap dealers are generally willing to trade only with counterparties that are located in "pro-creditor" jurisdictions that provide them with additional protections that are often not present in "pro-debtor" jurisdictions. ${ }^{186}$ Similar to the "race to the bottom" described above with respect to the jurisdiction of incorporation, pro-debtor jurisdictions need to make their insolvency regimes derivative-creditor friendly if they want swap dealers to trade with participants subject to their particular insolvency laws. ${ }^{187}$

Swap dealers worry about their ability to first terminate all of their OTC derivative trades with a counterparty in the event that the counterparty becomes insolvent. The swap dealers also worry about whether they would be able to set off the termination amounts that they owe their insolvent counterparty against the termination amounts that are owed to them by the insolvent counterparty. This is commonly referred to as close-out netting and is used to deal with the problem of cherry-picking. ${ }^{188}$

To facilitate the due diligence for swap dealers and other participants, the International Swap \& Derivatives Association routinely commissions legal opinions in different jurisdictions with respect to whether close-out netting is enforceable (pro creditor). So far, the ISDA has obtained legal opinions on close-out netting for fifty-eight jurisdictions. ${ }^{189}$ If a counterparty is not located in one of those jurisdictions, the counterparty will have difficulty in persuading dealers to trade with them.

As a practical matter, if a participant wants to trade actively with the global swap dealers, it either needs to be organized in a pro-creditor jurisdiction or it needs to lobby its government to reform their insolvency rules. ${ }^{190}$ For example, prior to insolvency reforms in Brazil and Mexico, a Brazilian or Mexican party that wanted to enter into OTC derivatives would typically need to

186 For a discussion of pro creditor versus pro debtor jurisdictions, see Robert R. Bliss, Bankruptcy Law and Large Complex Financial Organizations: A Primer, 27 Fed. Reserve Bank Chi. Econ. Persp., No. 1, 2003, at 48, 50-51.

187 For a discussion of these provisions, see generally Harold S. Novikoff \& Sandeep C. Ramesh, Special Bankruptcy Code Protections for Derivative and Other Financial Market Transactions, A.L.I.-A.B.A. Bus. L. Course Materials J., Oct. 2009, at 37.

188 William J. Bergman et al., Netting, Financial Contracts, and Banks: The Economic Implications 1, 4, 6 (Fed. Reserve Bank of Chi., Working Paper No. 2004-02, 2004), available at http://ssrn.com/abstract=505965; Robert R. Bliss \& George G. Kaufman, Derivatives and Systemic Risk: Netting, Collateral, and Closeout 3 (Fed. Reserve Bank of Chi., Working Paper No. 2005-03, 2005), available at http://ssrn.com/abstract=730648.

189 See Netting Opinion - List, ISDA, http://www.isda.org/docproj/stat_of_net_opin.html (last visited Feb. 23, 2014) (list of netting opinions); see also David Mengle, InT'L Swaps and Derivatives Ass'n, ISDA Research Notes: The Importance of Close-Out NetTING 4 (2010), available at http://www.isda.org/researchnotes/pdf/Netting-ISDAResearch Notes-1-2010.pdf.

190 ISDA has examples of pro creditor insolvency provisions that a jurisdiction should consider passing in order to obtain a favorable legal opinion on close-out netting. MenGLE, supra note 189 , at 4-5. 
form an offshore affiliate, organized in a jurisdiction that recognized close-out netting. ${ }^{191}$ Now that both Brazil and Mexico have enacted these reforms, these Brazilian and Mexican participants are no longer required to search out other jurisdictions in order to trade.

Even in the United States, there was concern during the late 1980s that US bankruptcy and bank insolvency law was not sufficiently pro-creditor, leading to the possibility that swap dealers may decide to concentrate their operations and trading in friendlier jurisdictions. ${ }^{192}$ Congress responded to these and other general safety and soundness considerations by reforming US insolvency law with respect to OTC derivative transactions. ${ }^{193}$ Some question today whether those particular reforms were good for financial markets, creating, for example, more volatility as counterparties are able to avoid the automatic stay and immediately liquidate their positions. ${ }^{194}$

\section{Counter Balances and Friction to Regulatory Arbitrage Incentives}

\section{The Value of Price Transparency and Safety to Swap Participants}

Regulatory arbitrage theoretically should not exist if the benefits of the regulations in question outweigh the costs of compliance. US policymakers and regulators argue that the Dodd-Frank regulations and reforms will make OTC derivatives markets more transparent, safe, and efficient, and create incentives to trade and clear in the United States as opposed to fleeing the jurisdiction. Chairman Gensler has consistently argued that "[i]t's critical that we do not retreat from reforms that will bring greater transparency and competition to the swaps market, lower costs for companies and their customers, and protect the public from the risks of these international markets." 195 Some market participants also share his vision for reform. ${ }^{196}$

If correct, in spite of all of the regulatory costs, volume may actually increase in the United States if non-US persons enjoy better pricing with less risk because of the Dodd-Frank reforms that outweigh the regulatory compliance costs and concerns. Many market participants, such as hedge funds, are anxiously awaiting the Dodd-Frank alternative to the arguably opaque and inefficient bilateral trading environment. ${ }^{197}$ In fact, many participants are already

191 Interview with Sergio Goncalves, former Partner, Gen. Counsel, Banco BBM (Oct. 15, 2007) (on file with author).

1926 Johnson, supra note 31, at 104.

193 For a discussion of US bankruptcy rules, see id.

194 Stephen J. Lubben, Derivatives and Bankruptcy: The Flawed Case for Special Treatment, 12 U. PA. J. Bus. L. 61, 61-62, 67, 77 (2009); Mark J. Roe, The Derivatives Market's Payment Priorities as Financial Crisis Accelerator, 63 Stan. L. Rev. 539, 546-549 (2011). 195 Examining Bank Supervision and Risk Management in Light of JPMorgan Chase's Trading Loss: Hearing Before the H. Comm. on Fin. Servs., 112th Cong. 128 (2012) (statement of Gary Gensler, Chairman, Commodity Futures Trading Comm'n).

196 Kenneth Griffin, We Must Overturn the Status Quo in Derivatives, Fin. Times (Oct. 26, 2009, 10:03 PM), http://www.ft.com/intl/cms/s/0/22f8fd28-c262-11de-be3a-00144feab49a .html\#axzz2AAdRb7LA ("Regulators must implement central clearing where appropriate and put the integrity of our capital markets ahead of the profits of a self-interested few."). 197 Kenneth C. Griffin, CEO, Citadel, Keynote Speech at the Federal Reserve Bank of Chicago Symposium: Public Policy Symposium on OTC Derivatives Clearing (Sept. 3, 2010) (author's notes). 
moving to clear OTC derivative trades due to credit risk concerns with swap dealers in the current market. ${ }^{198}$

US policymakers can point to historical examples of success that support their case that regulatory arbitrage is not necessarily the end result of regulation. After the stock market crash of 1929 and the global depression that followed, the stringent securities law reforms and vigorous policing of US equity markets by the SEC has resulted in perhaps the deepest capital markets in the world, historically attracting issuers from around the globe to issue in the United States. ${ }^{199}$ A similar case can be made based on the success of the OTC derivatives industry's sister, the exchange-traded derivative market consisting of exchange traded futures, options on futures, and options.

These promised benefits, however, may prove to be illusory. Unfortunately the CFTC has yet to make its case through empirical data or cost-benefit analysis that the benefits of the proposed regulation will exceed the regulatory burdens placed on participants.

\section{Legal Friction and Regulatory Arbitrage}

Legal uncertainty in the United States due to Dodd-Frank will surely drive regulatory arbitrage. Legal uncertainty, however, and a lack of a sophisticated judiciary in less sophisticated non-G20 jurisdictions may create enough friction to stunt the movement away from the United States or the G20. Although it will certainly be possible to set up derivative trading operations in less-regulated jurisdictions outside of the United States and other G20 jurisdictions, ${ }^{200}$ parties will need to consider the reasons (and the implications) as to why there is little regulation there.

A key concern is whether a jurisdiction has the judicial and legal certainty necessary to deal with inevitable conflicts and disputes between parties. As discussed above, has the jurisdiction worked out all of the statutory, regulatory, and common law concerns associated with close-out netting and insolvency rules? When the notional amount of derivative trades are measured in the hundreds of millions (if not billions) of dollars, it becomes imperative that the parties understand how a local court will interpret and enforce their ISDA Master Agreement and other related documents. Although the parties can certainly choose to litigate in New York, for example, it would be ironic to come back to a jurisdiction that you had initially fled due to its regulatory environment.

Issues such as service of process and sovereign immunity may also suddenly become serious legal risks in jurisdictions outside of the G20. Political and judicial corruption may also become a problem. Only time will tell if lessregulated jurisdictions will emerge where parties are confident that large-scale swap activity can occur and thrive.

198 Telis Demos \& Tracy Alloway, Funds Dash to Clearing Houses for Swaps, Fin. Times (May 10, 2012, 8:47 PM), http://www.ft.com/intl/cms/s/0/9ce83480-99e9-11e1-accb-00144f eabdc0.html\#axzz2sqx9bVxs.

199 See Ctr. for Capital Mkts. Competitiveness, Strengthening U.S. Capital MarKets: A Challenge for all Americans 9 (2008), available at http://www.capitalmarkets summit.com/files/2010/11/2008_Report.pdf.

200 See supra text accompanying notes 119-26. 


\section{Can Regulatory Arbitrage be Controlled or Eliminated?}

Congress has equipped the CFTC with extraordinary powers to control regulatory arbitrage, mandating that US persons comply with Dodd-Frank and giving the CFTC extraterritorial jurisdiction over the foreign activities of both US and non-US participants. In spite of the firepower given to the CFTC, however, it still remains to be seen whether such powers will be sufficient or whether regulatory arbitrage will reduce the current robust US trading markets to a sizable, but reduced, player in global OTC derivative trading.

The possibility of regulatory arbitrage occurring has recently been a question of great concern to global regulators. In a joint letter to Chairman Gensler of the CFTC dated October 17, 2012, the Chancellor of the Exchequer in the U.K., the Commissioner for Internal Markets and Services at the European Commission, the Minister of State for Financial Services of Japan, and the Minister of Finance for the Government of France expressed their general joint concerns about hasty regulation resulting in a fragmentation of the global markets caused by inconsistent regulation: "At a time of highly fragile economic growth, we believe that it is critical to avoid taking steps that risk a withdrawal from global financial markets into inevitably less efficient regional or national markets." ${ }^{201}$ Asian regulators have recognized a similar concern that the United States' failure to recognize the potential regulatory arbitrage could result in "increasing market fragmentation."202

As the various Dodd-Frank deadlines move forward, pundits worry about the possibility of the US market becoming isolated as non-US persons strive to avoid Dodd-Frank regulation:

Still, some bank executives said moving interbank swaps business outside the US could reduce US banks' ability to trade with customers in the long run. As counterparties move business abroad, that would reduce the pool of potential trading partners for US firms, potentially affecting their cost of hedging customer business. Another twist is that the rule could put some swaps, previously overseen by the CFTC because they involved at least one US counterparty, beyond the reach of the regulator as non-US banks move trading abroad. ${ }^{203}$

\section{A. Dodd-Frank and Regulatory Arbitrage}

From the initiation of this proposed regulatory reform agenda, US Treasury Secretary Geithner recognized that regulatory arbitrage was to be a consideration that would need to be dealt with on an international regulatory level:

We also will need to work with authorities abroad to promote implementation of complementary measures in other jurisdictions, so that achievement of our objectives is not undermined by the movement of derivatives activity to jurisdictions without adequate regulatory safeguards. ${ }^{204}$

201 Letter from George Osborne, Chancellor of the Exchequer, U.K. Gov't, et al., to Gary Gensler, Chairman, U.S. Commodity Futures Trading Comm'n (Oct. 17, 2012) [hereinafter Osborne et al.], available at www.cadwalader.com/thecabinet/get_doc.php?id=29723.

202 Foreign Regulators' Letter, supra note 13, at 1.

203 Martin Vaughan \& Katy Burne, Banks Opt Out in Swap Row: Singapore's DBS, Sweden's Nordea Won't Register to Trade With U.S. Firms, Wall St. J. (Oct. 22, 2012, 4:24 PM), online.wsj.com/article/SB10001424052970203400604578072221988442386.html. 204 Geithner, supra note 77, at 2-3. 
Although the United States is committed to eliminating regulatory arbitrage, based upon its frenetic and aggressive rulemaking efforts, it appears to be poised to do it principally through extraterritorial action, ${ }^{205}$ as opposed to harmonization and cooperation.

The potential regulatory arbitrage results of Dodd-Frank can be thought of as a circle with two concentric rings. The inner circle will consist of trading activity between US persons or trading activity between a US person and a non-US person, all of which are subject to Dodd-Frank regulation if they want to execute OTC derivative transactions. The first ring will consist of trading between non-US persons that are subject to the regulatory regimes of the other G20 regimes or trading between non-US persons that are subject to G20 regulation, and non-US persons that are not subject to G20 regulation. To the extent that there are regulatory advantages to trading in these G20 jurisdictions over trading in the United States under Dodd-Frank, they will avoid trading in the United States and abandon trading with US swap dealers or customers that are US persons.

The second or outer ring will consist of trading between parties that are not US persons or persons that are not subject to the laws of a G20 country. Assuming that the current model of bilateral trading proves to be less costly, more efficient, or easier than trading under the new Dodd-Frank or other G20 rules, it is inevitable that a non-US / G20 OTC derivative market will develop and probably flourish.

\section{Dodd-Frank Regulatory Arbitrage Provisions}

Congress and the US Treasury were aware from the beginning of the legislative process that the regulatory arbitrage issues were going to be difficult. The United States, however, moved relatively slowly in its effort to clarify its position on the issue. ${ }^{206}$

Dodd-Frank specifically provided numerous statutory provisions to deal with these concerns, providing the CFTC with extraterritorial jurisdiction. ${ }^{207}$

205 For a discussion of the United States' use of extraterritorial jurisdiction, see Kenneth R. Feinberg, Economic Coercion and Economic Sanctions: The Expansion of United States Extraterritorial Jurisdiction, 30 Aм. U. L. Rev. 323, 324-25 (1981).

206 The Commission has not given the public any formal guidance on what [Section 722(d)] means in practice. In the past, staff at the [CFTC] [has relied] on the assistance of foreign regulators for the supervision of entities located abroad, so long as the foreign jurisdiction is found to have a comparable regulatory structure in place. Unfortunately, we have not proposed a mechanism to do this with respect to any of the rules being put forth under Dodd-Frank. This has already created regulatory uncertainty for firms with global operations as they attempt to plan for the future. Not only will our failure to establish clear rules in this area leave firms unable to determine what their compliance obligations may be, but it will most certainly drain critical Commission resources if we attempt to respond to these questions on a case by case basis.

Harmonizing Global Derivatives Reform: Impact on U.S. Competitiveness and Market Stability: Hearing Before the Subcomm. on Gen. Farm Commodities and Risk Mgmt. of the H. Comm. on Agric., 112th Cong. 10 (2011) (statement of Jill E. Sommers, Comm'r, Commodity Futures Trading Comm'n).

207 See Robert L.D. Colby \& Andrew S. Fei, Potential Extraterritorial Application of Regulations Issued Under Title VII of the Dodd-Frank Act, J. L. Investment \& Risk Mgmt. Products, June-July 2011, at 1, 1-2; Michael Greenberger, The Extraterritorial Provisions of the Dodd-Frank Act Protects U.S. Taxpayers from Worldwide Bailouts, 80 U. Mo. Kan. 
Section 722 in Dodd-Frank (codified at 7 U.S.C. § 2) provides the general rule that Dodd-Frank is not intended to "apply to activities outside the United States unless those activities - '(1) have a direct and significant connection with activities in, or effect on, commerce of the [US]; or '(2) contravene such rules or regulations . . . as are necessary . . . to prevent the evasion of any provision of this Act ...." "208 A similar rule exists with respect to the SEC's jurisdiction over security-based swaps in Section 772(b). ${ }^{209}$ The interpretation of those exceptions, however, appears to be left up to the discretion and judgment of the CFTC and SEC. In particular, the CFTC staff has taken the position "as a clear expression of congressional intent that Dodd-Frank swap provisions apply to activities outside the US under certain circumstances." 210

Section 715 of Dodd-Frank provides the CFTC with teeth in punishing foreign swap markets if "the regulation of swaps . . . markets in a foreign country undermines the stability of the United States financial system . . .."211 In such a situation, the CFTC "may prohibit an entity domiciled in the foreign country from participating in the United States in any swap . . .."212 The net effect is that if the CFTC believes that a foreign market has not enacted sufficient reforms or rules such that it creates instability in the Unites States, it can prohibit the participants from such markets from trading in the United States, essentially blackballing players from these "rogue" jurisdictions from trading in the United States.

The CFTC is directed to "consult and coordinate with foreign regulatory authorities on the establishment of consistent international standards" 213 and is directed to "conduct a study of the effects (if any) of the position limits imposed ... on the movement of transactions from exchanges in the United States to trading venues outside the United States."214 The CFTC has also spent extensive time studying the issue. ${ }^{215}$

In addition to these regulatory arbitrage provisions, the CFTC has power with respect to the mandatory clearing requirement under Dodd-Frank to prescribe any rules "necessary to prevent evasions of the mandatory clearing requirements." 216

City L. Rev. 965, 965-66 (2012); Sean J. Griffith, Substituted Compliance and Systemic Risk: How to Make a Global Market in Derivatives Regulation, 98 Minn. L. Rev. (forthcoming 2014).

208 Dodd-Frank Act, Pub. L. No. 111-203, § 722(d), 124 Stat. 1673 (2010) (codified as amended at 7 U.S.C. § 2(i) (2012)) (emphasis added).

209 Dodd-Frank Act $\S 772$ (c) (codified as amended at 15 U.S.C. $§ 78 \mathrm{dd}$ (2012)).

210 Statement of Carlene Kim, Deputy Gen. Counsel, U.S. Commodity Futures Trading Comm'n Office of Gen. Counsel, at the U.S. Commodity Futures Trading Comm'n Global Markets Advisory Committee Meeting 24 (Nov. 7, 2012), available at http://www.cftc.gov /ucm/groups/public/@aboutcftc/documents/file/gmac_110712_transcript.pdf.

211 Dodd-Frank Act $§ 715$ (codified as amended at 15 U.S.C. $§ 8304$ (2012)).

$212 I d$.

213 Dodd-Frank Act $\S 752$ (codified as amended at 15 U.S.C. $\S 8325$ (a) (2012)).

214 Dodd-Frank Act $\$ 719$ (codified as amended 15 U.S.C. $\S 8307(a)(1)(2012)$ ).

215 See, e.g., U.S. Commodity Futures Trading Comm'n, CFTC-SEC Staff Roundtable on International Issues and Dodd-Frank, YouTuBE (Aug. 4, 2011), http://www.youtube.com /watch?v=4_2Fp9RdOJA.

2167 U.S.C. $\S 2(\mathrm{~g})(4)(\mathrm{A})(2012)$. 
As anticipated, there are already congressional attacks on the extraterritorial provisions. For example, the House has introduced H.R. 3283, entitled the Swap Jurisdiction Certainty Act, ${ }^{217}$ which is still awaiting passage. The bill would effectively reduce the extraterritorial reach of Sections 722 and $772 .^{218}$

\section{Exempting Foreign Exchange Swaps and Forwards}

A key concern of US policymakers was whether to subject foreign exchange swaps and forwards, a key portion of the global foreign exchange markets, to Dodd-Frank reforms. The rationale is probably two-fold. First, there is evidence that, in this particular segment of the OTC derivative market, much of Dodd-Frank regulation is probably unnecessary and may even be counterproductive. Second, there was possibly an unspoken concern that any increased regulation may drive the trading of foreign exchange swaps and forwards to other foreign exchange trading centers, such as London.

Section 721 of Dodd-Frank authorizes the Secretary of the Treasury ("Secretary") to issue a written determination exempting foreign exchange swaps, foreign exchange forwards, or both from the definition of a "swap" under the CEA. ${ }^{219}$ The US Treasury Secretary proposed in 2011 to exempt foreign exchange swaps and forwards from the mandatory clearing and exchange trading requirement, and to not count such swaps and forwards for determining whether a party was a swap dealer or major swap participant. ${ }^{220}$

Although the US Treasury appears ready to formally exempt these transactions from the reach of Dodd-Frank, there has been opposition to this action. ${ }^{221}$ In proposing to exempt foreign exchange swaps and forwards, the US Treasury noted these markets "already reflect many of the Dodd-Frank Act's goals including high levels of price transparency, effective risk management and electronic trading" and may actually be counterproductive with respect to the goals of Dodd-Frank. ${ }^{22}$ The US Treasury also noted that the foreign market requires physical settlement and fixed terms, has a well-functioning settlement

217 Swap Jurisdiction Certainty Act, H.R. 3283, 112th Cong. (2011).

218 See Curbing the Extraterritoriality of Dodd-Frank's Derivatives Regulation: An Examination of the Swap Jurisdiction Certainty Act, Milken Inst. (Feb. 9, 2012), http://www .milkeninstitute.org/publications/publications.taf?function=detail $\& I D=38801305 \&$ cat $=;$ see also Wallace Turbeville, The Ongoing Congressional Assault on International Derivatives Regulation, Dçmos (June 4, 2012), http://www.demos.org/blog/ongoing-congressional -assault-international-derivatives-regulation.

219 Determination of Foreign Exchange Swaps and Foreign Exchange Forwards Under the Commodity Exchange Act, 77 Fed. Reg. 69,694, 69,694 (Nov. 20, 2012).

220 Determination of Foreign Exchange Swaps and Foreign Exchange Forwards Under the Commodity Exchange Act, 76 Fed. Reg. 25,774, 25,775 (May 5, 2011).

221 Silla Brush, Swap Exemption May Post Risk to U.S. Financial System, Exchange Group Says, Bloomberg (June 7, 2011, 1:58 PM), http://www.bloomberg.com/news/2011-06-07 /foreign-swap-dodd-frank-exemption-may-open-loophole-exchange-group-says.html ("The exemption has also been opposed by the AFL-CIO labor union, Democratic Senators Carl Levin of Michigan and Maria Cantwell of Washington, and Americans for Financial Reform, a coalition of labor union and consumer watchdog groups.").

222 Silla Brush, U.S. Treasury Proposes Exemptions for Foreign-Exchange Swaps, BLoomBERG (April 29, 2011, 2:15 PM), http://www.bloomberg.com/news/2011-04-29/treasury-pro poses-dodd-frank-exemption-of-foreign-exchange-swaps-forwards.html. 
process, and shorter duration contracts in comparison to other OTC derivative markets. $^{223}$

In spite of the US Treasury's proposal to exempt foreign exchange forwards and swaps, the exemption has not yet been granted after eighteen months because of a perceived political sensitivity on the issue. It appears, however, that the US Treasury will reach a decision after the US presidential election in November. ${ }^{224}$ The CFTC, however, has issued no-action letters" ${ }^{225}$ "providing temporary relief to firms who would have had to register as swap dealers by the October 12 deadline. The relief means that firms do not have to count their foreign exchange swaps transactions in the $\$ 8$ billion calculation used to determine a firm's status as a swap dealer."226

The foreign exchange swap and forward markets are particularly vulnerable to regulatory arbitrage concerns. The foreign exchange markets, which would include foreign exchange swaps and forwards, are probably the largest and most liquid markets in the world. Sixty-five percent of the trading is also cross-border. ${ }^{227}$ The foreign exchange trading activities of more non-traditional participants has also increased. ${ }^{228}$ More problematic is that certain jurisdictions enjoy economy of scale advantages, such as London, over other jurisdictions. $^{229}$

The volume in North America is truly staggering for foreign exchange swaps and forwards. The Foreign Exchange Committee in its Semi-Annual Foreign Volume Survey in April 2012 reported that the average daily volume in foreign exchanges forwards was approximately $\$ 149$ billion and the average daily volume in foreign exchange swaps was $\$ 248$ billion. ${ }^{230}$

223 Press Release, U.S. Dep't of Treasury, Fact Sheet: Notice of Proposed Determination on Foreign Exchange Swaps and Forwards (April 29, 2011).

224 Emmanuel Olaoye, U.S. Treasury to Move by Year End on Plan to Exempt Forex Swaps, Sources Say, Reuters (Oct. 24, 2012, 5:23 PM), http://blogs.reuters.com/financial-regula tory-forum/2012/10/24/u-s-treasury-to-move-by-year-end-on-plan-to-exempt-forex-swaps -sources-say/.

${ }^{225}$ Letter from Gary Barnett, Dir., U.S. Commodity Futures Trading Comm'n, on Time Limited No-Action Relief (Oct. 12, 2012), available at http://cftc.gov/ucm/groups/public /@lrlettergeneral/documents/letter/12-21.pdf.

226 Olaoye, supra note 224.

227 Monetary and Econ. Dep't, Bank for Int'l Settlements, Triennial Central Bank Survey: Foreign Exchange and Derivatives Market Activity in April 2010, at 1 (2010) [hereinafter Triennial Central Bank Survey] ("As regards counterparties, the higher global foreign exchange market turnover is associated with the increased trading activity of 'other financial institutions' - a category that includes non-reporting banks, hedge funds, pension funds, mutual funds, insurance companies and central banks. among others."), available at $\mathrm{http}: / / \mathrm{www}$. bis.org/publ/rpfx10.pdf.

228 Id. ("Foreign exchange market activity became more global, with cross-border transactions representing 65 [percent] of trading activity in April 2010, while local transactions account for 35 [percent].").

229 Forex History: The Forex Past, Present and Future, Finexo, http://www.finexo.com /forex-education/forex-history.html (last visited Feb. 23, 2014) ("As Forex trading has grown, several international cities have emerged as market leaders. Currently, London, England has the greatest share of transactions with over 32 [percent] of the total trade volume.").

230 Foreign Exch. Comm., Semi-Annual Foreign Exchange Volume Survey (2012), available at http://www.newyorkfed.org/fxc/2012/aprfxsurvey2012.pdf. 
The BIS, in its 2010 triennial survey on foreign exchange, described the composition of global foreign exchange markets:

The relative ranking of foreign exchange trading centres has changed slightly from the previous survey. Banks located in the United Kingdom accounted for 36.7 [percent], against 34.6 [percent] in 2007, of all foreign exchange market turnover, followed by the United States (18 [percent]), Japan (6 [percent]), Singapore (5 [percent]), Switzerland (5 [percent]), Hong Kong SAR (5 [percent]) and Australia (4 [percent]). ${ }^{231}$

There are clearly other jurisdictions that would be anxious to pick up the slack if trading foreign exchange swaps and forwards became difficult or expensive in the United States.

\section{B. Understanding the Unspoken Approach to Global Regulation}

As discussed above, the CFTC is determined to eliminate regulatory arbitrage from occurring. A key to the strategy appears to be based upon the demographics of the global OTC derivative market and the importance of swap dealers to trading activity. The CFTC appears to be gambling that to the extent that the global swap dealers do business in the United States, the CFTC can use the extraterritorial powers given to them under Dodd-Frank to curtail regulatory arbitrage and create a regulatory floor for global OTC derivative regulation.

The CFTC has been leading the way in putting into place derivative regulation, moving "more quickly than other countries" with US officials "trying to prod the rest of the world to go along with tightened rules being created in the U.S. . . .."232 The CFTC and US Treasury have been aggressive in voicing their opinion that competing jurisdictions should follow their regulatory lead:

Last week, Geithner held a press conference and acknowledged the extraterritoriality tensions.

He warned other nations not to adopt rules that are softer in order to poach business from US markets, while also saying regulators need to figure out a sensible way to apply disjointed rules.

"And because in some areas US reforms are tougher or just different from the rules forthcoming in other markets, we need to figure out a sensible way to apply those rules to the foreign operations of US firms and the US operations of foreign firms," Geithner told reporters on Thursday. ${ }^{233}$

Chairman Gensler echoed Geithner's comments: “'We're trying to work hand in hand with the Europeans, trying to get similar comprehensive and comparable rules.' But he added it would be 'easier to defer to Europe' if European rules matched those developed in the US." 234

Others have also voiced frustrations with the US attitudes toward comity. " 'Part of the problem is the US rushed out their legislation and now it is in the business of pushing everyone else to follow suit,' said Anthony Belchambers,

231 Triennial Central Bank Survey, supra note 227.

232 Guevarra, supra note 151.

233 Huw Jones, ET, The New Alien Scaring Global Markets, Reuters (Feb. 5, 2012, 9:59

AM), www.reuters.com/article/2012/02/05/financial-regulation-et-idUSL5E8D2482201202 05 .

234 Tom Braithwaite et al., Push to Regulate Derivatives Is Under Strain, Fin. Times (July 8, 2011, 12:53 AM), http://www.ft.com/intl/cms/s/0/4340ee5a-a8e9-11e0-ab62-00144feabd c0.html\#axzz2sqx9bVxs. 
chief executive of the London-based Futures and Options Association."235 Jonathan Macey, in his article on regulatory arbitrage, would probably characterize the efforts of the United States to impose Dodd-Frank standards globally as "regulatory imperialism." 236

Similar to the importance of casinos to gambling, OTC derivative trading cannot exist at its current scale without the large OTC derivative swap dealers and their enormous derivative trading floors and "books" of business. If a regulator is able to control a global dealer, the regulator will indirectly control the dealer's customers and the rest of the market, domestic or global.

Global swap dealers have greatly enabled participants to trade by being willing to act as an intermediary, building huge books of business in the process. ${ }^{237}$ Due to their size, sophistication and huge rolodexes of customers and contacts, large derivative dealers are able to make markets in various derivative areas and facilitate the massive amount of trading that currently exists. Rather than having to locate a counterparty that needs exactly the offsetting position to a particular desired hedge, a participant instead can approach a dealer to enter into the offsetting position. After the dealer has entered into the trade with its customer, it then will enter into an offsetting position with another customer or other swap dealer to balance its book. Because of this particular business model, the CFTC through its rulemaking process is able to control not only the swap dealers, but also all of the swap dealers' customers.

It is clear that the CFTC has the ability to control the US activities of a dealer operating in the US. The question is then whether the United States is able to control the foreign activities of either a US or a foreign swap dealer. Although the OTC derivatives market is global, the swap dealers that control the vast majority of the trading are organized and headquartered either in the United States or in a G20 country. All of them also have substantial US operations. To the extent that the CFTC can, as a prerequisite to doing business in the United States, require a swap dealer to meet US standards (or comparable foreign standards) for its non-US business, it may be able to export US standards to the rest of the market.

The CFTC will be able to exert enormous influence over global markets if it can impose regulations on these global dealers. The largest swap dealers in the world identified by the ISDA are affectionately referred to as the G14 and control 82 percent of the total notional amount outstanding across the globe. ${ }^{238}$ Of these fourteen global swap dealers, six are organized in the United States, three in the United Kingdom, two in France, two in Switzerland, and one in Germany. ${ }^{239}$ The concentration of trading activity in the US is even greater: "According to the Office of the Comptroller of the Currency, five large

235 Id

236 See Macey, supra note 119, at 1354.

237 See 6 Johnson, supra note 31, at 4.

238 These include Bank of America, Barclays, BNP Paribas, Citigroup, Credit Suisse, Deutsche Bank, Goldman Sachs, HSBC, JPMorgan Chase, Morgan Stanley, Royal Bank of Scotland, Société Générale, UBS, and Wells Fargo. David Mengle, Int'l Swaps And Derivatives Ass'n, ISDA Research Notes: Concentration of OTC Derivatives Among Major DeAlers 2, 3 (2010), available at http://www2.isda.org/functional-areas /research/research-notes.

239 Id. at 2. 
banks_-JPMorgan Chase (JPM), Bank of America (BAC), Citigroup (C), Morgan Stanley (MS), and Goldman Sachs (GS)-hold almost 96 percent of the notional value of all derivatives contracts [in the United States]."240

The remaining large swap dealers that are truly global players are also principally located in other G20 jurisdictions. Although Japanese swap dealers have lost much of their luster from the late 1980s, they still exert global influences. Canada ${ }^{241}$ and Australia ${ }^{242}$ both also have world-class derivative dealers.

In addition to controlling the lion's share of global OTC derivative activity, these dealers also have significant business activity in the United States. The CFTC, by subjecting these global swap dealers to Dodd-Frank, potentially could compel non-US swap dealers to conform to US rules worldwide.

The following is a summary of the global OTC derivative business done by a few key swap dealers across the world:

\begin{tabular}{|l|c|c|c|}
\hline & $\begin{array}{c}\text { Number of countries } \\
\text { in which company } \\
\text { operates }\end{array}$ & $\begin{array}{c}\text { Percentage of } \\
\text { employees outside } \\
\text { the United States }\end{array}$ & $\begin{array}{c}\text { Percentage of OTC } \\
\text { derivative activity in } \\
\text { United States }\end{array}$ \\
\hline Goldman Sachs & 33 countries $^{243}$ & $48 \%^{244}$ & $49 \%^{245}$ \\
\hline
\end{tabular}

240 Karen Weise, A Dodd-Frank Regulatory Exemption Grows by 7,900\%, BLOOMBERG BusinessweEK (Apr. 20, 2012), http://www.businessweek.com/articles/2012-04-20/a-dodd -frank-regulatory-exemption-grows-by-8-000-percent.

241 See Canadian Sec. Adm'rs Derivatives Comm., CSA Consultation Paper No. 91407, Derivatives: Registration 10 (2013), available at http://www.osc.gov.on.ca/en /SecuritiesLaw_csa_20130418_91-407_derivatives-registration.htm. Royal Bank of Canada, Toronto Dominion, and The Bank of Nova Scotia all have active global derivative books. See Letter from Canadian Mkt. Infrastructure Comm. to Alberta Sec. Comm'n et al. (June 17, 2013), available at http://www.osc.gov.on.ca/documents/en/Securities-Category9-Com ments/com_20130617_91-407_cmic_en.pdf.

${ }^{242}$ Australian Swap Dealers Being Reporting OTC Derivatives Trades to ASIC Through DTCC's Global Trade Repository Service, Bus. Wire (Oct. 2, 2013, 6:15 PM), http://www .businesswire.com/news/home/20131002006561/en/Australian-Swap-Dealers-ReportingOTC-Derivatives-Trades. In October 2012, the Australian Prudential Regulation Authority, the Australian Securities and Investment Commission, and the Reserve Bank of Australia issued a report recognizing the need for increased regulation of OTC derivatives, and identified the additional OTC derivative reforms proposed in the Corporations Legislation Amendment Bill 2012 introduced into the Australian Parliament. Austl. Prudential Regulation Auth. et al., Report on the Australian OTC Derivatives Market 1 (2012), available at http://www.asic.gov.au/asic/pdflib.nsf/LookupByFileName/REP309-Report-on-the-Aus tralian-OTC-Derivatives-Market-October-2012.pdf/\$file/REP309-Report-on-the-Austra lian-OTC-Derivatives-Market-October-2012.pdf.

243 Office Locations, Goldman SACHs, http://www.goldmansachs.com/who-we-are /locations/index.html (last visited Feb. 24, 2014).

244 Goldman Sachs, 2011 Annual Report 205 (2012), available at http://www .goldmansachs.com/investor-relations/financials/fulfillment/reports/GS_AR11_AllPages.pdf (out of 33,300 total employees, 16,100 were not in the Americas).

245 Id. at 93 (credit exposure of OTC derivatives in the Americas equaled \$36,591 out of a total of $\$ 74,148$ in millions). 


\begin{tabular}{|l|l|l|l|}
\hline Deutsche Bank & 72 countries $^{246}$ & $89 \%^{247}$ & $35 \%^{248}$ \\
\hline UBS & 57 countries $^{249}$ & $66 \%^{250}$ & $35 \%^{251}$ \\
\hline
\end{tabular}

Filings with the Federal Reserve show that 77 percent of Morgan Stanley's fairvalue derivatives and liabilities were outside the United States. ${ }^{252}$ Similar filings show "that JPMorgan Chase \& Co. had 59 percent of its $\$ 188$ billion in overseas branches or international affiliates; Citigroup Inc. (C) had 53 percent of \$122 billion; and Bank of America Corp. had half of \$125 billion in non-US operations in the same period." ${ }^{253}$ Specific examples also illustrate this global activity. $^{254}$

It appears that some foreign swap dealers not numbered in the G14 are already willing to register as a swap dealer in the United States in order to participate in the US market. ${ }^{255}$ For example, Standard Chartered has indicated that it will register, although it will be careful to ensure that its other entities do not. ${ }^{256}$ Recently, however, some swap dealers have abandoned the US markets in the face of Dodd-Frank regulation. ${ }^{257}$

246 Deutsche Bank, Annual Review 201133 (2012), available at https://www.db.com/ir /en/download/Annual_Review_2011.pdf.

247 Id. at 32.

248 Id. at 70 (credit exposure of OTC derivatives in North America equaled_28,070 out of a total _79,624 in millions). "Within the OTC derivatives business [Deutsche Bank's] largest concentrations were . . . in Western Europe and North America . . .." Id. at 71.

249 UBS, AnNuAl Report 2011234 (2012), available at http://www.ubs.com/global/en /about_ubs/investor_relations/annualreporting/2011/_jcr_content/par/teaserbox_6c86/teaser _acb3/linklist/link_9f50.228736590.file/bGluay9wYXRoPS9jb250ZW50L2RhbS9zdGF0a WMvZ2xvYmFsL2ludmVzdG9yX3JlbGF0aW9ucy9hbm51YWwyMDExL0FSMjAxMV91 LnBkZg==/AR2011_e.pdf.

${ }^{250} I d$. (21,746 employees working in the United States out of 64,820 total employees).

${ }^{251}$ Id. at 123 (credit exposure of OTC derivatives in North America equaled CHF 13,003 out of a total CHF 37,205 in millions).

252 Brush, supra note 180.

${ }^{253}$ Id. "The provision raised the stakes for banks because their swaps business is global. In 2008, Sally Davies, a Fed adviser, said that between 55 percent and 75 percent of US banks' notional derivatives exposure was with non-US residents." Id.

254 For example, New York-based Goldman Sachs's largest counterparty for credit derivatives on the eve of the credit crisis in June 2008 was Deutsche Bank AG (DB)'s London branch; its thirdlargest interest-rate derivatives counterparty was JPMorgan's London branch; and its largest counterparty for currency products was Royal Bank of Scotland Plc's London branch, according to a 2010 report from the Financial Crisis Inquiry Commission, a US panel that investigated the crisis.

Id.

255 Vaughan \& Burne, supra note 203 ("Several larger, internationally focused banks, however, have reached the conclusion they are better off registering with the CFTC.").

256 Nitin Gulabani, who heads Standard Chartered PLC's foreign-exchange, rates and credit desks, said at the same event that the London-based, emerging markets-focused bank will register some of its entities while ensuring that that [sic] others do not do business with U.S. counterparties.

"We are looking at making sure that entities are either registered, or don't trade with U.S. persons," he said.

Id.

257 See infra text accompanying notes 367-68. 
To the extent that trading in the United States remains a priority for all of these global derivatives dealers, the CFTC has an extraordinary opportunity to export its standards. Through its extraterritorial jurisdiction, it potentially can require these same institutions to conduct their non-US OTC derivative activities pursuant to Dodd-Frank standards.

\section{CFTC Interpretive Guidance and Policy Statement}

The most concrete steps that the United States has taken with respect to these regulatory arbitrage concerns has been the issuance by the CFTC of the proposed interpretive guidance and policy statement entitled Cross-Border Application of Certain Swaps Provisions of the Commodity Exchange Act the "Proposed Guidance"), issued on July 12, 2012. ${ }^{258}$ The CFTC then issued final guidance on July 26, 2013, a little more than a year after issuing the proposed guidance, entitled Interpretive Guidance and Policy Statement Regarding Compliance with Certain Swap Regulations (the "Final Guidance"). ${ }^{259}$ With respect to security-based swaps, a relatively small part of the OTC derivative market, the SEC has also issued proposed guidance on application of US rules and regulations to cross-border situations. ${ }^{260}$

\section{Introduction to the Final Guidance}

Although the Proposed and Final Guidance statements are important steps in dealing with the regulatory arbitrage and extraterritoriality issue, their complexity and controversial provisions may, ironically, only add to regulatory arbitrage pressures. While the guidance will be critical in applying the CFTC's extraterritorial reach, the CFTC waited until July of 2012 to release the Proposed Guidance, only months before the Dodd-Frank mandates begin to become effective. It then waited over a year to issue the Final Interpretive Guidance. $^{261}$

258 Cross-Border Application of Certain Swaps Provisions of the Commodity Exchange Act, 77 Fed. Reg. 41,214 (July 12, 2012) [hereinafter Proposed Interpretive Guidance] (to be codified at 17 C.F.R. pt. 1).

259 Interpretive Guidance and Policy Statement Regarding Compliance with Certain Swap Regulations, 78 Fed. Reg. 45,292 (July 26, 2013) (to be codified at 17 C.F.R. pt. 1) [hereinafter Final Guidance].

260 Cross-Border Security-Based Swap Activities; Re-Proposal of Regulation SBSR and Certain Rules and Forms Relating to the Registration of Security-Based Swap Dealers and Major Security-Based Swap Participants, 78 Fed. Reg. 30,968 (May 23, 2013) (to be codified at 17 C.F.R. pts. 240, 242, 249), available at http://www.sec.gov/rules/proposed/2013 134-69490.pdf. This proposed rule has also come under similar criticisms as those of the CFTC. See Julian Hattem, Businesses Concerned About SEC International Swaps Proposal, HiLl (Aug. 22, 2013, 12:40 PM), http://thehill.com/blogs/regwatch/pending-regs/318283 -businesses-concerned-about-sec-international-swaps-proposal-. The proposed SEC rule is equally as detailed and comprehensive as those issued by the CFTC (650 pages), although they cover only security-based swaps - a relatively small portion of the OTC derivatives market. A complete discussion of the SEC rules is beyond the reach of this article.

261 Final Guidance, 78 Fed. Reg. at 45,292. For a detailed discussion of the Final Proposed Guidance, see CFTC Finalizes Cross-Border Swaps Guidance and Establishes Compliance Schedule, DavisPolk (July 30, 2013), http://www.davispolk.com/sites/default/files /07.30.13.CFTC_.Cross_.Border_0.pdf. See also Legal Alert: An End-User's Guide to the 
Like most of the CFTC regulatory projects, the Proposed Guidance was long, detailed, and complex, running over thirty pages when published in the Federal Register. The Final Guidance is even more complex, with the Guidance Section and the various appendices running sixty-nine pages when published in the Federal Register. The Final Guidance must also be read in conjunction with an exemptive order that provides for various phase-ins of the rules issued contemporaneously with the Final Interpretive Guidance ${ }^{262}$ that extends (with certain key changes) an earlier exemptive order. ${ }^{263}$

Public response to the Proposed Guidance was swift and detailed. Three hundred five different parties have provided suggested comments and critiques to the proposed regulation. Out of the 288 parties, 14 were foreign regulators, 33 were foreign and domestic industry trade groups representing their members, 14 were financial institutions, and 7 market participants such as exchanges and clearinghouses, with the balance being individuals and other miscellaneous commenters. ${ }^{264}$ The complexity of the proposed guidance itself is only equaled by many of the comment letters critiquing it. ${ }^{265}$

The introduction to the proposed guidance laid out the CFTC's purpose in issuing the guidance:

Whether a person's swap dealing activities or swap positions may require registration as a swap dealer or major swap participant, respectively, and the application of the related requirements under the CEA to swaps involving such persons;

Application of the clearing, trade execution, and certain reporting and recordkeeping provisions under the CEA, to cross-border swaps involving one or more counterparties that are not swap dealers or major swap participants; and

Describes the policy and procedural framework under which the Commission may permit compliance with a comparable regulatory requirement of a foreign jurisdiction to substitute for compliance with the requirements of the CEA. ${ }^{266}$

In highlighting the need for the guidance, the CFTC noted that Bear Stearns, Lehman, AIG, JPMorgan Chase, and Long Term Capital Management all conducted extensive derivative trading activities through non-US affiliates or branches that exposed the United States to financial risks. ${ }^{267}$ The CFTC

CFTC's Final Cross-Border Guidance, SutherLand (Aug. 8, 2013), http://www.sutherland .com/files/upload/AnEnd-UsersGuidetotheCFTCsFinalCross-BorderGuidance.pdf.

262 Exemptive Order Regarding Compliance With Certain Swap Regulations, 78 Fed. Reg. 43,785 (July 22, 2013) (to be codified at 17 C.F.R. pt. 1).

${ }^{263}$ Final Exemptive Order Regarding Compliance With Certain Swap Regulations, 78 Fed. Reg. 858, 858-59 (Jan. 7, 2013) (to be codified at 17 C.F.R. pt. 1).

264 See Comments for Proposed Rule 77 FR 41213, U.S. Commodity Futures Trading Commission, http://comments.cftc.gov/PublicComments/CommentList.aspx?id=1234 (last visited Feb. 24, 2014).

${ }^{265}$ For example, in one of the more comprehensive critiques, SIFMA, a key trade group for the securities industry in the United States, wrote a sixty-nine page comment letter providing comments on the 155 pages of proposed guidance. Final Exemptive Order Regarding Compliance With Certain Swap Regulations, 78 Fed. Reg. at 862 n.30. See also SIFMA Submits Comments to the CFTC on Guidance Related to Cross-Border Application of Certain Swaps Provisions, SIFMA (Aug. 27, 2012), www.sifma.org/issues/item.aspx?id=8589940053.

266 Proposed Interpretive Guidance, 77 Fed. Reg. 41,214, 41,214 (July 12, 2012) (to be codified at 17 C.F.R. pt. 1).

267 Id. at 41,215. Commissioner Gensler noted that Long Term Capital Management booked the "vast majority" of its swaps "in its affiliated partnerships in the Cayman Islands." Gary Gensler, Chairman, U.S. Commodity Futures Trading Comm'n, Statement of Support (June 
believes that even though large financial institutions may conduct their activities through non-US (i.e., offshore) affiliates, in reality the entity is operating as a "single business" and should therefore be regulated as a single entity:

These large financial institutions effectively operate their businesses as a single business, by virtue of the relationship with the parent company and to each other, with the constituent parts inextricably linked to each other. The interconnected nature of the relationships among the affiliated entities within a corporate group means that a risk in any part of this group, whether in the United States or abroad, can quickly spread throughout the organization and jeopardize the financial integrity of the entire group. $^{268}$

Based on this perceived integration and unity of operation, the CFTC believes that both the US activities, as well as the non-US trading activities should be subject to the reforms.

Under Dodd-Frank, financial institutions that "participate in the swaps market as swap dealers or major swap participants ("MSPs") . . . must register and are subject to greater oversight and regulation."269 This registration requirement is key to understanding the reach of the proposed guidance.

Prior to issuing the proposed guidance, the CFTC received extensive comment on the Dodd-Frank regulatory arbitrage issue. In the introduction to the Proposed Guidance, the CFTC summarized the concerns and questions that participants had about the reach of Dodd-Frank. First, participants wanted the CFTC to define "the nature of the connections to the United States that would require a non-U.S. person to register as a swap dealer or MSP under the CEA and the Commission's regulations." 270 The CFTC noted the commentators generally believed that "swap dealing activity directly with U.S. counterparties should be registered with the Commission as swap dealers" but that "swap dealing conducted outside of the U.S. between non-U.S. persons is not sufficiently connected to the U.S. to warrant swap dealer registration." ${ }^{271}$ Commentators also noted that non-US swap dealers that limit their trading only to US persons that are registered swap dealers should not have to register. ${ }^{272}$

Second, commentators wanted the CFTC to define which "Dodd-Frank Act requirements apply to the swap activities of non-U.S. persons, U.S. persons, and their branches, agencies, subsidiaries and affiliates outside of the United States." 273 The CFTC noted that commentators generally believed that "entities outside the United States should comply with rules adopted under the Dodd-Frank Act with respect to requirements applicable to specific swaps, but should be subject to home country supervision by their home country regulators

29, 2012), available at http://www.cftc.gov/PressRoom/SpeechesTestimony/opagensler$117 \mathrm{~b}$.

268 Proposed Interpretive Guidance, 77 Fed. Reg. at 41,216. The CFTC further noted that "[i]n many of the largest financial institutions, the overall business operates as a tightly integrated network of business lines and services conducted through various branches or affiliated legal entities which are under the unified management of the parent entity." Id.

269 Id.

$270 I d$. at $41,217$.

271 Id. at 41,217 n.20.

$272 I d$.

$273 I d$. at $41,217$. 
with respect to requirements applicable at the entity level."274 Commentators further noted that "a U.S. entity must not be able to conduct swap business with non-U.S. persons free from regulation under the Dodd-Frank Act by establishing a non-U.S. affiliate and conducting the swap business through the affiliate." 275

Third, commentators wanted the CFTC to define "the circumstances under which the Commission would consider permitting a non-U.S. person to comply with the regulatory regime of its foreign jurisdiction instead of complying with the Dodd-Frank Act and the Commission's regulations promulgated thereunder." 276 The CFTC noted that commentators generally believed that "deference to comparable home country regulation accords with principles of international comity and is consistent with the approach taken by U.S. banking regulators with respect to non-U.S. banks." 277 Commentators further noted "comparability should be determined based on whether the home country entity-level requirements are reasonably designed to achieve the same policy objectives as the corresponding requirements under the Dodd-Frank Act." ${ }^{278}$ Finally, commentators believed that the CFTC "should defer to the home country, entity-level requirements only when they are comparable." 279

In the Final Guidance, the CFTC has set forth the provisions and approaches that will be used to deal with the questions of regulatory arbitrage and the exercise of extraterritorial jurisdiction. In the commentary to the final guidance, the CFTC laid out the following areas that the final guidance covers:

- interpretation of the term US person;

- swap dealer and MSP registration;

- scope of the term "foreign branch" of a US bank and consideration of when a swap should be considered to be with the foreign branch of a US bank;

- a description of the Entity-Level Requirements and Transaction-Level Requirements;

- the categorization of swaps provisions as either Entity-Level or Transaction-Level Requirements;

- substituted compliance, including an overview of the principles guiding substituted compliance determinations for Entity-Level and TransactionLevel Requirements, a general description of the process for comparability determinations, and a discussion of conflicts arising under foreign privacy and blocking laws;

- application of the Entity-Level Requirements and Transaction-Level Requirements to swap dealers and MSPs; and

\footnotetext{
274 Id. at 41,217 n. 21.

275 Id.

276 Id. at $41,217$.

277 Id. at 41,217 n.22.

278 Id.

279 Id.
} 
- application of the swaps provisions where both parties to a swap are neither swap dealers nor MSPs. ${ }^{280}$

A thorough discussion of each of these areas of guidance is beyond the scope of this article. The following, however, will briefly describe the application of the Dodd-Frank to cross-border situations and the CFTC's stated response to controlling regulatory arbitrage and exercising its extra-territorial jurisdiction.

The key issues to be resolved by the Final Guidance are, first, whether a non-US swap dealer or major swap participant is subject to the Entity-Level Requirements imposed by Dodd-Frank, which deal with how a swap dealer or major swap participant conducts its business both in the United States and outside the United States. Second, the Final Guidance discusses when a transaction will be subject to the Transaction-Level Requirements imposed by Dodd-Frank, again both when transacted inside the United States and outside the United States.

As an initial matter, and as well be described below, the Final Guidance provides a definition as to who will be characterized as a US person for purposes of the Dodd-Frank rules. The Final Guidance provides a detailed and comprehensive definition of a US person for purposes of the application of Dodd-Frank to cross-border activities and trading with non-US persons. ${ }^{281}$ As will be described below, the application of both the Entity-Level Requirements and the Transaction-Level Requirements will depend upon whether a party is characterized as a US person.

280 Final Guidance, 78 Fed. Reg. 45,292, 45,292-93 (July 26, 2013) (to be codified at 17 C.F.R. pt. 1).

281 A full analysis of the implications of the final definition of a US person is beyond the scope of this discussion. The definition under the Final Guidance includes the following as a US person:

(i) Any natural person who is a resident of the United States; (ii) any estate of a decedent who was a resident of the United States at the time of death; (iii) any corporation, partnership, limited liability company, business or other trust, association, joint-stock company, fund or any form of enterprise similar to any of the foregoing (other than an entity described in prongs (iv) or (v), below) (a "legal entity"), in each case that is organized or incorporated under the laws of a state or other jurisdiction in the United States or having its principal place of business in the United States; (iv) any pension plan for the employees, officers or principals of a legal entity described in prong (iii), unless the pension plan is primarily for foreign employees of such entity; (v) any trust governed by the laws of a state or other jurisdiction in the United States, if a court within the United States is able to exercise primary supervision over the administration of the trust; (vi) any commodity pool, pooled account, investment fund, or other collective investment vehicle that is not described in prong (iii) and that is majority-owned by one or more persons described in prong (i), (ii), (iii), (iv), or (v), except any commodity pool, pooled account, investment fund, or other collective investment vehicle that is publicly offered only to non-US persons and not offered to US persons; (vii) any legal entity (other than a limited liability company, limited liability partnership or similar entity where all of the owners of the entity have limited liability) that is directly or indirectly majority-owned by one or more persons described in prong (i), (ii), (iii), (iv), or (v) and in which such person(s) bears unlimited responsibility for the obligations and liabilities of the legal entity; and (viii) any individual account or joint account (discretionary or not) where the beneficial owner (or one of the beneficial owners in the case of a joint account) is a person described in prong (i), (ii), (iii), (iv), (v), (vi), or (vii).

Id. at $45,316-17$. 
Once it is determined that a party or a transaction is subject to the various requirements, the Final Guidance then provides guidance as to whether a party may look to non-US requirements, referred to in the Final Guidance as "substituted compliance," or whether it will be subject to the Dodd-Frank rules.

There is an important exception to the definition of US person with respect to the determination of whether or not a non-US person is required to register as a swap dealer or major swap participant. Essentially a swap dealer that is a non-US person will be required to register as a swap dealer if its swap dealing with US persons exceeds the "de minimis" notional threshold amount of $\$ 8$ billion. ${ }^{282}$ Upon registration, the swap dealer would be subject to the various prudential, business conduct, reporting, clearing, and trading requirements of Dodd-Frank. For purposes of measuring the notional amount, "a U.S. person should count all of its swap dealing activity, whether with U.S. or non-U.S. counterparties." 283 In other words, if a non-US dealer exceeded the de minimis threshold amount, it would need to register.

However, non-US persons are generally allowed to exclude their swap dealing transactions with a foreign branch of a US swap dealer. ${ }^{284}$ This is because the CFTC believes that the application of Dodd-Frank to the US swap dealer would result in appropriate standards being applied to the non-US dealer with respect to the transactions in question. ${ }^{285}$ This carve-out is also important to protect US dealers. If such a carve-out didn't exist, non-US dealers that might otherwise not be subject to Dodd-Frank regulation might avoid doing business with US dealers in order to avoid being caught by Dodd-Frank. A similar analysis is applied with respect to whether a non-US person qualifies as a "major swap participant," a qualification that entails additional obligations and duties under Dodd-Frank. In making that determination, a non-US party is allowed to exclude its trading activities with non-US parties. ${ }^{286}$

\section{Entity-Level Requirements}

The Final Guidance holds that a registered swap dealer or major swap participant will be subject to the Entity-Level Requirements. ${ }^{287}$ The Final Guidance provides guidance as to whether a non-US person will be required to register as a swap dealer or MSP and thus be subject to these requirements. After it is determined that a non-US person is required to register as a registered swap dealer or major swap participant, the question is whether "substituted compliance" will be allowable.

The Entity-Level Requirements essentially deal with how a party will manage its derivative business. The Entity-Level Requirements are broken into a First Category and a Second Category. ${ }^{288}$ The First Category requirements

282 See Further Definition of "Swap Dealer," "Security-Based Swap Dealer," "Major Swap Participant," "Major Security-Based Swap Participant," and "Eligible Contract Participant," 77 Fed. Reg. 30,596, 30,634 (May 23, 2012) (to be codified at 17 C.F.R. pt. 1).

283 Final Guidance, 78 Fed. Reg. at 45,318.

284 Id. at $45,324$.

285 Id.

286 Id. at 45,324-25.

287 Id. at 45,331.

$288 I d$. 
include (i) capital adequacy, (ii) chief compliance officer, (iii) risk management, and (iv) swap data recordkeeping. ${ }^{289}$ The Second Category requirements include swap data repository reporting (SDR Reporting) and Large Trader Reporting. ${ }^{290}$

\section{Availability of Substituted Compliance}

The Final Guidance provides that a US swap dealer of a US MSP must comply with both the First Category and Second Category Entity-Level Requirements. $^{291}$ For a registered non-US swap dealer or registered MSP, "substituted compliance generally would be available for a non-U.S. swap dealer or non-U.S. MSP . . . regardless of whether the counterparty is a U.S. person or non-U.S. person" 292 for the First Category.

For the Second Category, the Final Guidance provides that for a registered non-US swap dealer or a registered non-US MSP, "substituted compliance generally would be available for a non-U.S. swap dealer or MSP only where the counterparty is a non-U.S. person."293 In addition, for Second Category Requirements, the Final Guidance provides that substituted compliance with respect to SDR Reporting "only where the swap counterparty is a non-U.S. Person", and only where "the [CFTC] has direct access . . to the relevant swap data that is stored at the foreign trade repository." 294 The Final Guidance, however, does not allow substituted compliance for Large Trader Reporting. ${ }^{295}$

As explained above, the Entity-Level Requirements are only applicable to registered US swap dealers or registered MSPs and are not applicable to a nonUS person who is not a US-registered swap dealer or registered major swap participant.

\section{Transaction-Level Requirements}

The Final Guidance provides guidance as to whether a transaction is subject to the Transaction-Level Requirements. The Transaction-Level Requirements are broken in Category A and Category B. All of the Transaction-Level Requirements except for the business conduct standards are Category A. ${ }^{296}$ The Category A Transaction-Level Requirements include the following: (i) clearing and swap processing; (ii) margin and segregation requirements for uncleared swaps; (iii) trade execution; (iv) swap trading relationship documentation; (v) portfolio reconciliation and compression; (vi) real-time public reporting; (vii) trade confirmation; and (viii) daily trading records. ${ }^{297}$

\footnotetext{
289 Id.

$290 I d$.

291 Id. at 45,368 n.1.

292 Id. at 45,338.

293 Id.

294 Id.

295 Id.

296 Id. at 45,336.

297 Id.
} 


\section{Category A Requirements}

The Final Guidance clarifies that the Category A Transaction-Level Requirements for US swap dealer or a US MSP (except for the foreign branch of a US Bank that is a registered US swap dealer or MSP) are applicable regardless of whether the counterparty is not a US person. ${ }^{298}$ In other words, there is no substituted compliance regardless of where the transaction is executed.

For a foreign branch of a US Bank that is a US swap dealer or MSP, the Category A requirements are applicable for transactions with a US person. ${ }^{299}$ Substituted compliance, however, is available for transactions for such a foreign branch with a foreign branch of a US Bank that is a US swap dealer or MSP or a non-US person, regardless of whether the transaction is guaranteed by a US person. ${ }^{300}$

For a non-US-registered swap dealer or MSP, the Category A requirements are applicable for transactions with a US person. ${ }^{301}$ Substituted compliance, however, is available for transactions for such a foreign branch with a foreign branch of a US Bank that is a US swap dealer or MSP or a non-US person if the transaction is guaranteed by a US person. ${ }^{302}$ The Category A transaction requirements do not apply if the transaction is entered into with a non-US person that is not guaranteed by a US person. ${ }^{303}$

\section{Category B Requirements}

The Final Guidance clarifies that the Category B Transaction-Level Requirements for a US swap dealer or a US MSP (except for the foreign branch of a US Bank that is a registered US swap dealer or MSP) are applicable regardless of whether the counterparty is not a US person. ${ }^{304}$ In other words, there is no substituted compliance for Category B Transaction-Level Requirements regardless of where the transaction is executed.

For a foreign branch of a US Bank that is a US swap dealer or MSP, the Category B requirements are applicable for transactions with a US person. ${ }^{305}$ The Category B requirements otherwise do not apply.

\section{Non-Swap Dealers and Non-MSP}

The Final Guidance provides special rules for parties that are not a registered swap dealer or registered MSP, regardless if it is a US person or non-US person. This guidance applies to application of the clearing, trade execution, real-time public reporting, Large Trader Reporting, SDR Reporting and swap data recordkeeping (the "Appendix F Requirements"). ${ }^{306}$

\footnotetext{
$298 I d$. at 45,369.

299 Id.

$300 \mathrm{Id}$.

$301 \mathrm{Id}$.

302 Id.

303 Id.

$304 I d$.

305 Id.

$306 \mathrm{Id}$. at 45,370 .
} 
A US person that is not a registered swap dealer or MSP must comply with the Appendix F Requirements. ${ }^{307}$ A non-US Person, that is guaranteed by a US person, must comply with the Appendix F Requirements with a US person but may apply substituted compliance for trades with a non-US person that is guaranteed by a US person (but compliance is not required for trades with a non-US person that is not guaranteed by a US person). ${ }^{308}$

A non-US person that is not a registered swap dealer or MSP, must comply with the Appendix F requirements for trades with a US person, but is not required to otherwise comply. ${ }^{309}$

\section{Process of Determining Substituted Compliance}

The general rule is that the CFTC will enforce its regulations on an extraterritorial basis if a non-US person is required to register with the CFTC as either a swap dealer or a major swap participant or, in certain circumstances, such person is a non-US person but trades with a US person, or a non-US person that is guaranteed by a US person. However, the CFTC in the Final Guidance states that "[c]onsistent with CEA section 2(i) and comity principles, the Commission's policy generally is that eligible entities may comply with a substituted compliance regime under certain circumstances, subject, however to ... its examination authority and its enforcement authority." 310 This policy is referred to in the Final Guidance as "Substituted Compliance."

Under the Final Guidance, the CFTC will allow compliance with non-US rules (in place of compliance with the Entity-Level or Transaction-Level Requirements), if the CFTC determines that "such home jurisdiction's requirements ... are comparable with and as comprehensive as the corollary area(s) of regulatory obligations ...."311 In a significant break with the Proposed Guidance, the CFTC has agreed that instead of comparing substituted compliance on a rule-by-rule basis, it will instead rely upon an "outcomes-based report":

An outcomes-based approach ... means that the Commission is likely to review the requirements of a foreign jurisdiction for rules that are comparable to and as comprehensive as the requirements of the Dodd-Frank Act, but it will not require that the foreign jurisdiction have identical requirements to those established under the DoddFrank Act. ${ }^{312}$

The CFTC, however, notes that it may still be required to compare the rules on a piecemeal basis because of foreign jurisdictions adopting their rules on an incremental basis. ${ }^{313}$

The Final Guidance sets out the general principles for evaluating a foreign jurisdiction's regulations:

In evaluating whether a particular category of foreign regulatory requirement(s) is comparable and comprehensive to the applicable requirement(s) under the CEA and Commission regulations, the Commission will take into consideration all relevant

\footnotetext{
307 Id.

$308 I d$

309 Id.

310 Id. at 45,342 .

311 Id.

$312 I d$. at $45,342-43$.

313 Id. at 45,343 .
} 
factors, including but not limited to, the comprehensiveness of those requirement(s), the scope and objectives of the relevant regulatory requirement(s), the comprehensiveness of the foreign regulator's supervisory compliance program, as well as the home jurisdiction's authority to support and enforce its oversight of the registrant. ${ }^{314}$

The paragraph concludes again by noting that "comparable does not necessarily mean identical." 315

The Final Guidelines provide that the determination of substituted compliance will be made by the CFTC based upon a submission by an applicant. ${ }^{316}$ The applicant, among others, may be either a foreign regulator, a non-US entity, a US bank that is a swap dealer or MSP with respect to its foreign branches, or a trade association. ${ }^{317}$ Any analysis would be made in conjunction with the regulators of the foreign jurisdiction for which substituted compliance is requested. ${ }^{318}$ In making a determination of substituted compliance, it would enter into a memorandum of understanding or similar agreement with such a regulator. ${ }^{319}$

\section{Reaction to the Final Guidance}

Although the issuance of the Final Guidance is helpful, there is still serious concern about legal uncertainty and application of the US rules in crossborder situations. Already several regulators and trade groups have called for the CFTC to take a "less mechanical approach to determine whether to accept foreign regulatory standards." ${ }^{320}$ One commentator has still recently noted that the "intensely global nature of derivatives trading can easily result in the application of multiple and incompatible legal requirements across legal systems." 321

ISDA, the principal trade group in the area, is strongly encouraging that the CFTC and other regulators engage in an "inter-jurisdictional recognition of derivatives regulation through a principles-based substituted compliance methodology,"322 as well as raising other concerns. ${ }^{323}$ The Investment Company Institute had similar concerns with the guidance offered by the SEC on secur-

\footnotetext{
314 Id.

315 Id.

316 Id. at 45,344 .

317 Id.

$318 I d$.

319 Id.

320 John Bakie, Regulators Urged to Adopt Principles-Based Substituted Compliance, Trade News (Aug. 23, 2013), http://www.thetradenews.com/news/Asset_Classes/Deriva tives/Regulators_urged_to_adopt_principles-based_substituted_compliance.aspx.

321 James E. Schwartz et al., The Path Forward for EU-US Derivatives Regulation, IFLR (Aug. 27, 2013), http://www.iflr.com/Article/3247985/IFLR-magazine/The-path-forward -for-EU-US.

322 Int'L Swaps Derivatives Ass'N, Methodology for Regulatory Comparisons 1 (2013), available at http://www2.isda.org/regions/united-states.

323 Stephen O'Connor, Comment: A Framework for Regulatory Co-operation, Fin. Times (Aug. 20, 2013, 12:35 PM), http://www.ft.com/intl/cms/s/0/b5c341ca-0694-11e3-ba04 -00144feab7de.html\#axzz2cODkgBDo.
} 
ity-based swaps and also encourages the SEC to act consistently with the CFTC. ${ }^{324}$

In specific jurisdictions, the mechanical implementation of the Final Guidance is also raising concerns. The United States' efforts to grapple with substituted compliance with certain Asian jurisdictions is already raising issues. ${ }^{325}$ Similar concerns are echoed about harmonization with the E.U. under the Final Guidance. $^{326}$

\section{The Harmonization Challenge}

Since the G20 announcement in 2009, there has been an enormous amount of emphasis among the G20 countries on their OTC derivative reform commitments to harmonize their regulations in order to avoid regulatory arbitrage. Unfortunately, however, there is no enforcement mechanism to require such harmonious actions.

\section{Consultation}

Scholars believe that regulators have strong incentives to coordinate financial regulation in global markets. Jonathan Macey, in his seminal article on explaining cross-border cooperation, notes the keys to situations where regulators can successfully battle cross-border regulatory arbitrage:

One of the conditions that leads to regulatory globalization is successful regulatory arbitrage. When it is possible for firms and industries easily to avoid the reach of domestic regulators, those regulators will have strong incentives to engage in "cartellike" behavior, coordinating with regulators in the jurisdictions to which regulated entities are moving in order to retain even diluted influence over the activities of such entities. $^{327}$

Given the global stakes in properly regulating OTC derivative markets, regulators have been particularly focused on consulting and harmonizing OTC derivative reforms.

There are several key efforts to facilitate discussion and consultation among national regulators. As discussed above, one of the key groups that is hosted by the BIS is the OTC Derivatives Working Group, ${ }^{328}$ which has been

324 Letter from Karrie McMillan, Gen. Counsel, Inv. Co. Inst., and Dan Waters, Managing Dir., ICI Global, to Elizabeth M. Murphy, Sec'y, Sec. and Exch. Comm'n (Aug. 21, 2013), available at $\mathrm{http}: / / \mathrm{www}$.ici.org/pdf/27482.pdf.

325 Timothy Sifert, CFTC Rules Divide Asia, IFRAsia (July 20, 2013), http://www.ifrasia .com/cftc-rules-divide-asia/21097716.article.

326 See Philip Stafford, Quick View: US-EU Swaps Trading Deal Is Not the End of the Story, Fin. Times (July 16, 2013, 1:29 PM), http://www.ft.com/intl/cms/s/0/3507888e-edfd -11e2-a325-00144feabdc0.html\#axzz2f5LyZe3Y.

327 Macey, supra note 119, at 1375.

328 The ODWG is led by representatives of CPSS, IOSCO, and the European Commission ("EC"). The SEC co-chairs the ODWG on behalf of IOSCO. The ODWG includes international standard setters and authorities responsible for transforming the G-20 commitments into standards and regulations. Jurisdictions include: Brazil, Canada, China, France, Germany, Hong Kong, Japan, Korea, United Kingdom, and United States. The ODWG also includes representatives from the European Central Bank ("ECB"), Bank for International Settlements ("BIS"), International Monetary Fund ("IMF"), and FSB. The ODWG makes regular progress reports to the FSB, assessing the adequacy of progress being made to fully and consistently implement the 
actively monitoring the progress of the G20 jurisdictions toward passing OTC derivative reforms and produced the interim G20 progress reports discussed above. US regulators have also been willing participants in this group. ${ }^{329}$

The OTC Derivatives Regulators' Forum, hosted by the Federal Reserve Bank of New York, is another key consultation group. ${ }^{330}$ In an effort to promote additional harmonization among different jurisdictions, international regulators formed in 2009 the OTC Derivative Regulators' Forum. The Forum is composed of regulators from thirteen different countries, the European Union, the Committee on Payment and Settlement Systems, and the International Organization of Securities Commissions. ${ }^{331}$

The Forum has set out the following objectives to increase global harmonization:

Provide mutual assistance among the regulators in carrying out their respective authorities and responsibilities with respect to OTC derivatives CCPs and trade repositories, and with respect to the broader roles and implications of these infrastructures in the financial system; Promote consistent public policy objectives and oversight approaches for OTC derivatives CCPs and trade repositories, including the development of international cooperative oversight arrangements that may be applied to individual systems; Adopt, promote, and implement consistent standards, such as the CPSS [Committee on Payment and Settlement Systems]-IOSCO Recommendations for Central Counterparties (RCCPs), in setting oversight and supervisory expectations; Coordinate the sharing of information routinely made available to regulators or to the public by OTC derivatives CCPs and trade repositories; Effectively deal with common issues collectively and consistently; [and] Encourage strong and open communication within the regulatory community and with the industry. ${ }^{332}$

It is unclear at the current time how much the forum's meetings will serve to decrease the risk of regulatory arbitrage.

Both the United States and the FSB have been particularly active, working with the IOSCO and the CPSS (hosted by the BIS), to help harmonize and develop consistent and harmonious OTC derivative reform standards that can be adopted by different jurisdictions. ${ }^{333}$ Although these standard-setting organizations are important, it is still up to the actual jurisdictions to adopt these standards either in whole or in a piecemeal fashion.

As mentioned above, a particularly successful example of developing standards (but not necessarily having them enacted) is the Margin Requirements Paper jointly produced by the CBS and the IOSCO. ${ }^{334}$ The Margin Require-

G-20 commitments to central clearing, trading on exchanges and electronic trading platforms, reporting to TRs, and capital requirements.

JoINT REPORT, supra note 115, at 3 n.5.

329 "Staffs are participating in the Financial Stability Board ("FSB") OTC Derivatives Working Group ("ODWG"), which monitors progress being made in implementing OTC derivatives market reforms." $I d$. at 3 .

330 Id. at 12 n. 42 .

331 Press Release, Fed. Reserve Bank of N.Y., A Global Framework for Regulatory Cooperation on OTC Derivative CCPs and Trade Repositories app. 1 (Sept. 24, 2009), http://www .newyorkfed.org/newsevents/news/markets/2009/ma090924.html.

332 Id

333 JOINT REPORT, supra note 115 , at 3.

334 Basel Comm. on Banking Supervision, Bd. of the Int'l Org. of Sec. Comm'ns., supra note 169 , at 1 . 
ments Paper, however, has generated considerable attention and controversy. Similar to the Proposed Guidance, many industry participants have written comment letters. Since the comment period opened, the BIS has received 101 comment letters, of which approximately 37 were trade groups representing financial institutions and approximately fifty were from individual financial institutions. $^{335}$

Regulators agree that it is important that the margin rules governing OTC derivatives need to be similar (if not identical) for cleared OTC derivatives as well as the traditional non-cleared transactions. In fact, margin and collateral standards are one of the top drivers for regulatory arbitrage. In a show of solidarity with IOSCO, Chairman Gensler noted that the draft document's approach to margin standards "would lower the risk of financial entities, promote clearing and help avoid regulatory arbitrage." 336 Although there is no mechanism to ensure that the G20 jurisdictions adopt consistent margin requirements, the consultative paper is a start at cross-border cooperation on the issue. $^{337}$

As discussed above, a key difficulty in these consultative approaches is convincing jurisdictions that they should adopt the particular approaches developed by these organizations:

IOSCO standards are not legally binding - so the organisation cannot force individual states to comply in full with its standards. But the body has set up an assessment and enforcement division, which is tasked with examining whether its standards have been applied. In extreme cases, it could expel a member country for not complying although that would be a last resort. ${ }^{338}$

David Wright, the secretary general of IOSCO, noted "[i]t is unlikely we will see a single regulator with the legal power in every country in the world to enforce standards." 339 He continued, however, by stating that "no country wants to see its name last on a list of countries adopting high-quality practices. Our role is to encourage compliance as far as humanly possible." 340

Perhaps the best-recognized effort to harmonize international financial regulation involves the efforts to standardize bank capital requirements between banks. Commentators have noted that the efforts of CBS operating

335 Margin Requirements, supra note 172.

336 Jim Brunsden \& Silla Brush, Basel Group Seeks Tougher Rules for Non-Centrally Cleared Swaps, Bloomberg Businessweek (July 7, 2012), http://www.businessweek.com /news/2012-07-06/basel-group-seeks-tougher-rules-for-non-centrally-cleared-swaps; Elliott Holley, IOSCO Chief Calls for Greater Global Collaboration, TrADE News (July 27, 2012), http://www.thetradenews.com/news/Trading_Execution/Industry_issues/IOSCO_chief _calls_for_greater_global_collaboration.aspx?terms=IOSCO+Chief+Calls+for+Greater+Glo bal+Collaboration.

337 For a discussion of the issues involved in setting these margin standards, see Brunsden \& Brush, supra note 336.

338 Holley, supra note 336.

339 Id.

340 Id. Wright noted the aspirational goals for these efforts:

Imagine in ten years, we'll have the best set of rules not just in a few countries, but all around the world .... If we can do this job of supporting high quality securities standards around the world, investors can have confidence they will be treated, wherever they trade. That's a world we should aspire to.

Id. 
under the auspices of the BIS "is perhaps the most significant recent development in terms of substantive international supervision of banking-the formulation of uniform guidelines governing the measurement and enforcement of capital adequacy of banks." 341 The committee's efforts have resulted in "a multilateral convergence of regulatory standards."342

The costs of maintaining bank capital can directly affect bank profitability and thus can drive regulatory arbitrage. The US General Accounting Office noted that "[b]ecause holding capital is costly for banks, differences in regulatory capital requirements could influence costs, prices, and profitability for banks competing under different capital requirements." 343

One of the key forums for harmonizing bank capital regulation that is facilitated through the BIS is the CBS. ${ }^{344}$ Although the CBS enjoys enormous influence, it is only a forum and does not have the power to promulgate or enforce regulations. ${ }^{345}$ In this particular area, however, regulators from the different jurisdictions agreed to adopt the capital adequacy guidelines as they have been developed. ${ }^{346}$ Although the industry has run into trouble in refining, revising, and updating these standards, as witnessed by the proliferation of Basel I, II, and III, regulators have been able to achieve consistent standards across multiple jurisdictions in an important regulatory area. ${ }^{347}$

Unfortunately, although the G20 all committed themselves to meet the G20 commitments discussed above, they did not create a way to develop one single set of reforms or a way to bind themselves to all adopt the same standards. One commentator has noted that the "G20 has effectively commandeered the regulatory agenda since the financial crisis broke, but its mechanisms for executing the many commitments agreed are not clear either." 348

The G20 has most certainly lost an opportunity to create uniformity and conformity by permitting each country to draft its own rules and regulations. Instead of taking the approach to regulate capital adequacy through the various Basel accords, each country has instead promulgated its own rules and regulations, with the caveat that it will try to harmonize its regulation with that of other countries.

3413 Michael P. Malloy, Banking Law and Regulation $§ 15.02$, at 15-28.3 (2d ed. Supp. 2013).

342 Id. at $\S 15.02$, at $15-29$.

343 U.S. Gov't Accountability Office, GAO-08-953, Risk-Based Capital: New Basel II Rules Reduced Certain Competitive Concerns, but Bank Regulators Should Address Remaining Uncertainties 4 (2008).

344 Basel Committee on Banking Supervision, Bank Int'L Settlements, http://www.bis .org/bcbs/index.htm (last visited Feb. 24, 2014).

345 "The BCBS is the primary global standard-setter for the prudential regulation of banks and provides a forum for cooperation on banking supervisory matters. Its mandate is to strengthen the regulation, supervision and practices of banks worldwide with the purpose of enhancing financial stability." Bank for Int'L Settlemments, Basel Committee ON BANKING Supervision CHARTER 1 (2013), available at http://www.bis.org/bcbs/charter.pdf.

346 See About the Basel Committee, Bank InT'L Settlements, http://www.bis.org/bcbs /about.htm (last updated June 10, 2013).

347 See id.

348 Phil Davis, Global Standards are Still a Far-off Goal, Fin. Times (Apr. 8, 2012, 4:10 AM), www.ft.com/cms/s/0/f735697c-77e2-11e1-b237-00144feab49a.html. 


\section{Kinks in Harmonizing Regulation Across Jurisdictions}

It remains to be seen how the harmonization efforts will unfold as the G20 countries attempt to put into place a completely new regulatory regime to regulate OTC derivatives. These difficulties emerge for many reasons based upon a jurisdiction's expertise and experience with OTC derivatives and with the concerns and preferences of the participants who are organized or trade in that jurisdiction. There is also concern that jurisdictions, such as the United States, will insist on determining whether or not a jurisdiction's regulatory structure is comparable to their own.

It was hard enough for the G20 to draft general guidelines that all countries could agree to in 2009 when they committed to reform OTC derivative regulation by 2012 . It will prove even tougher however, to reduce these general principles and concepts to detailed and useful rules and regulations: "But after the broad concepts are written into law, then begins the rule making process by agencies in the US, or national securities regulators across Europe, to turn the concepts into practical realities." 349 Guy Sears, director of wholesale at the U.K.'s Investment Management Association noted that,

"[i]t's fantastic that our leaders want to do things ... . There is a will to act, but at the moment there is more communication than co-ordination. The top guys in most countries are aware of the overlaps and underlaps between regulations, but for political and other reasons they can't do anything about them."350

It is clear that all G20 countries would prefer regulatory regimes that do not incentivize participation based upon regulatory advantages. There can be difficulties, however, in reconciling particularly difficult issues. Edouard Vieillefond, managing director in the regulation policy and international affairs division at France's Autorité des Marchés Financiers, said: "By far we would prefer a system based on equivalence and mutual recognition to avoid double or triple regulation. There will need to be changes on both sides." ${ }^{351}$ Mr. Vieillefond further said:

On 90 per cent of the rules we agree with the US. But if we don't have the same list of derivatives for central clearing, the same rules for margining and capital including the same capital and collateral requirements for uncleared bilateral derivatives, it won't be manageable. We need to converge. ${ }^{352}$

Although heroic efforts are being made to harmonize regulations, there may be philosophical or ideological differences between competing jurisdictions that can result in inconsistent regulation. ${ }^{353}$ Commentators have already noted differences between Singapore and the United States and even with the

349 Telis Demos, Financial Reforms: Regulators Aim to Make "Middle Office" a Safer Place, Fin. Times (Apr. 13, 2012, 5:35 PM), www.ft.com/cms/s/0/27810e0e-7f7e-11e1 -b3d4-00144feab49a.html.

350 Davis, supra note 348.

351 Braithwaite et al., supra note 234 (internal quotations omitted).

352 Id. (internal quotations omitted).

353 The risks incurred when jurisdictions are crossed, as highlighted by the RBC case, is also a consistent theme.

For example, the US and Europe seem set to have different rules on what counts as acceptable "margin", the collateral posted at clearing houses. Europe is looking at allowing a wider range of financial products, in part to accommodate some riskier sovereign bonds.

Demos, supra note 349. 
European Union. ${ }^{354}$ Singapore, although not a G20 country, has been anxious to participate as well, already releasing its derivatives regulatory reforms. ${ }^{355}$ Commentators have noticed, however, that the reforms differ from Dodd-Frank in several respects. ${ }^{356}$ Commentators have also noted differences between the United States and the European Union. ${ }^{357}$ Analyzing and dealing with such differences can be time consuming and difficult, requiring great effort to compare jurisdictions. ${ }^{358}$ Even if the statutory reforms are similar, the real work involves turning these statutes into comprehensible and usable rules and regulations. $^{359}$

A key factor in creating these harmonious structures is a jurisdiction's willingness to defer to another jurisdiction's rules for activities being conducted there:

354 See E.T. Phones Home: Why the Reach of U.S. Derivatives Law Matters (With Important Updates on Singapore and Europe), Снатнам Fin., http://www.chathamfinancial.com/etphones-home/ (last visited Feb. 24, 2014).

355 See id.

356 Indeed, last week Singapore released its derivatives regulatory proposal, offering market participants the opportunity to consider further the scope of differences in worldwide regulatory approaches. Like the U.S. and E.U. regulatory regimes, Singapore's proposal reveals a determination to implement requirements that reflect lessons learned from the financial crisis. At the same time, however, Singapore has sought to exercise great care to ensure that commerce is not disrupted where there is no systemic risk concern. On this latter priority, Singapore's proposed approach differs from Dodd-Frank in several noteworthy ways:

1. Financial end users with small derivatives exposures are not subject to clearing requirements

2. Financial entities retain the freedom to transact in the venue they deem most efficient

3. Non-financial end users do not appear likely to be subject to margin requirements on noncleared trades

4. Transactions are not required to be reported on a real-time basis.

Id.

357 See id. The Alternative Investment Management Association also noted that the E.U. rules are proposing to require that "sufficiently liquid OTC derivatives to be traded on exchanges or organized trading facilities" versus the US standard. See Letter from Stuart J. Kaswell, Exec. Vice President \& Managing Dir., Gen. Counsel, Managed Funds Ass'n, and Jiøí Król, Dir. of Gov't \& Regulatory Affairs, Alt. Inv. Mgmt. Ass'n, to David A. Stawick, Sec'y of the Comm'n., Commodity Futures Trading Comm'n 14 n.50 (Feb. 6, 2013), https:// www.managedfunds.org/wp-content/uploads/2013/02/CFTC-Further-Cross-Border-Guid ance-Letter-MFA-AIMA-Final-Letter.pdf [hereinafter Alt. Inv. Mgmt. Ass'n Letter].

358 See generally Clifford Chance, Int'l Swaps and Derivatives Ass'n, Regulation of OTC Derivatives Markets: A Comparison of EU and US Initiatives (2012), available at http://www.cliffordchance.com/publicationviews/publications/2012/09/regulation_of _otcderivativesmarkets-0.html (comparing EU and US regulatory initiatives).

359 In other global news, the European Union last week signaled what would be a notable departure from certain rules proposed by U.S. regulatory authorities. The European Securities and Markets Authority - the key financial rulemaking body in the E.U. - indicated that foreign exchange (FX) forwards would likely be subject to bilateral margin requirements. By contrast, the US Treasury Department (and the Monetary Authority of Singapore) proposed exempting FX forwards from the salient economic requirements of the Dodd-Frank Act. Such differences, when paired with uncertainties around the territorial reach of U.S. and E.U. law, raise important questions about which rules would apply to cross border transactions.

E.T. Phones Home: Why the Reach of U.S. Derivatives Law Matters (With Important Updates on Singapore and Europe), supra note 354. 
European Commissioner Michel Barnier of the Internal Market and Services division has also called on [Chairman] Gensler and the CFTC to consider the impact of applying Dodd-Frank regulations to foreign markets.

"The U.S. has shown initiative in developing rules for the derivatives market," Barnier said, IFR Asia reports. "I now call on U.S. authorities to show leadership in applying them fairly. [U.S. regulators] must be prepared to rely on equivalent rules in host countries." 360

As discussed above, the United States is willing to defer to other jurisdictions for swap activity occurring outside its border if the rules are comparable. ${ }^{361}$ However, the Unites States is creating rules and regulations that allow the United States to dictate what they consider to be consistent and comparable with US regulation.

Small differences between competing jurisdictions' rules can also make a difference. Given the size and volume of OTC derivative transactions, what appears to be comparable may turn out to be quite different. In assessing the effect of differences between jurisdictions with respect to certain rules, Jamie Dimon, the CEO of JPMorgan Chase noted:

"If JPMorgan overseas operates under different rules than our foreign competitors, we can no longer provide the best products and services to our U.S. clients or our foreign clients.... The rules at the transaction level about margin reporting, all those requirements may enable Deutsche Bank to make the better deal." 362

\section{Motivations for Differing Rules and Regulations}

It may be difficult to harmonize the various OTC rules because different countries may have different motivations or reasons for their own particular versions of derivative reforms. These fundamental differences between jurisdictions have long been a part of the regulatory arbitrage that can go on in cross-border taxation ${ }^{363}$ and other regulatory arbitrage situations.

Understanding the rationales and reasons for disagreements over crossborder taxation rules between countries may be useful to understand why it may be difficult to harmonize OTC derivative regulation:

Rules vary because of: (1) different policy choices-the political consensus about tradeoffs may vary among societies with different values, traditions, and expectations; (2) different judgments about the impact of given rules- to the extent that all

360 Daniel Purt, International Regulators Prepared to Challenge CFTC's Cross-Border Actions, Bank Credit News (July 25, 2012), http://bankcreditnews.com/news/international -regulators-prepared-to-challenge-cftcs-cross-border-actions/4786/.

361 See supra Part III.B-C.

362 Silla Brush, CFTC Skips 'Intergalactic' Power in Dodd-Frank Guidance, BloomBerg (June 29, 2012, 3:36 PM), http://www.bloomberg.com/news/2012-06-29/cftc-skips-intergal actic-swaps-power-in-dodd-frank-guidance.html.

363 See H. David Rosenbloom, The David R. Tillinghast Lecture International Tax Arbitrage and the "International Tax System", 53 TAx L. Rev. 137, 153 (2000); see also Reuven S. Avi-Yonah, Commentary, The David R. Tillinghast Lecture International Tax Arbitrage and the "International Tax System", 53 TAx L. Rev. 167, 167 (2000); Mitchell A. Kane, Strategy and Cooperation in National Responses to International Tax Arbitrage, 53 EMORY L.J. 89, 91 (2004); Phillip R. West, Foreign Law in U.S. International Taxation: The Search for Standards, 3 FLA. TAx. REv. 147, 149, 171 (1996) (noting that cross-border arbitrage transactions "involve the favorable and inconsistent tax treatment of an item by two or more jurisdictions"). 
rule making requires decisions to be made without full knowledge of the potential impact, it is quite plausible for different decision-making groups (countries) to arrive at alternative determinations; (3) politics-here used in the sense that different political systems permit or facilitate different access to rulemakers and allow different forms of power and influence; (4) randomness; (5) path dependence; and (6) resources-a country could determine that an otherwise attractive rule is unrealistic due to administrative, resource, and technical skill constraints. ${ }^{364}$

As the United States struggles to deal with G20 jurisdictions that are less anxious than others to enact harmonious regulation, it may need to deal with the fact that, like in the cross-border tax arena, the parties will need to agree to disagree on certain details and aspects of the final reforms.

Asian regulators have also noted, with respect to OTC derivative reforms, the importance of appreciating that different jurisdictions may have different policies and concerns in enacting specific regulations: "Moreover, just as the CFTC has proposed requirements that are tailored to the US market, there is also a need for other regulators to cater for special characteristics of their local markets." 365

For example, many countries may appreciate the need to strengthen OTC derivative regulation, but do not see the need for the heavier aspects of DoddFrank. For example, jurisdictions such as Canada and Australia did not suffer the same level of financial panic that occurred during the Great Financial Crisis and believe that they are already prudently managing their jurisdictions' premier financial institutions. Other countries may only have limited OTC derivative trading and see no reason to create a regulatory infrastructure that they believe is well beyond their jurisdiction's needs.

\section{4. "Reverse" Extraterritorial Jurisdiction}

As discussed above, even many friendly G20 jurisdictions appear to have lost their patience with the United States' unwillingness to compromise and their extraterritorial approach to regulating non-US institutions. The concern is whether this discontentment will eventually stymie cooperation and harmony with respect to regulation.

If the differences between the United States' and other G20 jurisdictions' reforms become intractable, the US swap dealers and other US persons may find themselves the subject of regulatory retaliation by foreign jurisdictions. "Chris Allen, managing director at Barclays Capital, warned that a broad application could lead to overlapping or even conflicting regulation from foreign regulators, who could be tempted to retaliate against broad U.S. rules, by applying their own rules in a far reaching way." 366 The end result could be "recipro-

364 Diane M. Ring, One Nation Among Many: Policy Implications of Cross-Border Tax Arbitrage, 44 B.C. L. Rev. 79, 88-89 (2002).

365 Foreign Regulators' Letter, supra note 133, at 4 . Specifically, the regulators noted that "in the case of Hong Kong, Australia and Singapore, we are studying whether local market liquidity can justify implementation of mandatory trading of OTC derivatives products on exchanges or electronic trading platforms, and the form of trading venue which will best suit the purpose of improving pre-trade price transparency." Id.

366 Alexandra Alper, Bankers Air Fears Over Scope of Swaps Rules, Reuters (Feb. 8, 2012, 5:50 PM), http://www.reuters.com/article/2012/02/08/us-financial-regulation-swaps -idUSTRE81709I20120208. 
cal foreign regulatory oversight in U.S. markets" 367 with much confusion and little cooperation. This could result in US institutions such as JPMorgan Chase and Citibank having to comply with G20 rules (inconsistent with Dodd-Frank) in the United States because of their swap activities in these G20 jurisdictions. This possibility was probably never seriously contemplated when US policymakers were drafting Dodd-Frank and the CFTC was drafting rules.

\section{E. Trading Outside of the US}

The possibility that swap participants will pull back from US markets because of regulatory arbitrage concerns is already becoming a reality:

Banks in Asia are already pulling back on trading derivatives with their U.S. counterparts over fears of being sucked into new rules, the chief of the International Swaps and Derivatives Association, or ISDA, said Thursday.

"We have heard there is some pullback," Robert Pickle, Chief Executive of ISDA said in an interview in Sydney. "It is an indication that people are thinking of who they are dealing with and it's driven not by who they want to do business with or credit worthiness; it's driven by regulatory concerns," he said. ${ }^{368}$

More troubling is the recent decisions of DBS Group Holdings, a large Singaporean bank and swap dealer, and Nordea Bank, a large Swedish bank, to not "register with U.S. regulators to trade complex derivatives with U.S.-based financial companies. . ." "369 DBS complained that it "doesn't see the 'immediate commercial benefits' of making the investment necessary to comply with the strengthened U.S. rules . . . ."370 Other banks are considering similar actions, "[b]ut some mid-sized non-U.S. banks have told their brokers to stop doing trades with U.S. firms, in the hope of avoiding the $\$ 8$ billion threshold and the burden of becoming a U.S.-regulated dealer." 371

As the registration date approaches requiring foreign banks to register as swap dealers in the United States, numerous foreign banks have balked at the requirement. Prior to the CFTC granting a limited temporary waiver ${ }^{372}$ with respect to the registration requirement for foreign banks, "many foreign banks stopped trading swaps both with their [US] headquarters and with their overseas units" to avoid the swap dealer registration requirement. ${ }^{373}$

Similar to the approach adopted by the United States with respect to activity in G20 countries, the United States and G20 also seem to be betting that a swap dealer of the necessary size, talents, and connections will not emerge that is not subject to US or other G20 derivative regulation. Given the proper incentives, however, it is hard to imagine a creative investment banker not being able to put together such an entity, creating a situation of regulatory arbitrage where

367 Id

368 Guevarra, supra note 43.

369 Vaughan \& Burne, supra note 203.

370 Id.

371 Luke Jeffs \& Nia Williams, Dodd-Frank Forces European Banks to Review U.S. Deals, REuTERs (Oct. 26, 2012, 12:30 PM), http://www.reuters.com/article/2012/10/26/us-europe -derivatives-doddfrank-idUSBRE89P0UZ20121026.

372 Letter from Gary Barnett, supra note 225, at 3-4.

373 Vaughan \& Burne, supra note 203. 
a financial institution can trade completely outside of the proposed reforms in the United States and the other G20 countries.

One issue with regulatory arbitrage is that it is often difficult to locate a party, such as a swap dealer, in a nonconforming jurisdiction that provides the same infrastructure, sophistication, capabilities, and personnel as in a higherregulated conforming jurisdiction. However, unlike other analogous situations involving regulatory arbitrage, parties will have no difficulty trading in nonconforming markets due to the unique nature of bilateral OTC derivatives markets.

One puzzling aspect of this issue is that in spite of all of the regulatory preparations going on in the United States and G20 jurisdictions, global OTC derivative trading done through bilateral agreements continues unabated. As measured by the notional amount, the BIS estimates that the volume of OTC derivatives was $\$ 32$ billion higher in December of 2012 than it was in December of 2010. ${ }^{374}$ Many customers, in fact, continued to drag their feet to prepare for the reforms ${ }^{375}$ as the G20 countries attempt to put in place an arguably new, transparent, and improved regulatory environment and trading infrastructure. All of this suggests that parties appear to be unimpressed with the purported gains from a new regulatory environment and appear content to continue trading on a bilateral basis.

Since the early 1980s, global financial markets that trade OTC derivative markets have existed across the globe. There currently already exist financial institutions that have the capability to make markets and trade OTC derivatives in almost every region. Each of these institutions have trading floors, personnel, and the sophistication to continue trading in the same way that they have done since the market began. In analogous scenarios involving regulatory arbitrage, many nonconforming jurisdictions often have to build infrastructure to support demand caused by changes in regulation. With respect to OTC derivative reform, this infrastructure is essentially already in place.

\section{Non-US/G20 Jurisdictions}

It is certainly possible to find sophisticated financial institutions that already trade OTC derivatives in jurisdictions outside of the G20. The jurisdictions of organization of the 200 primary members of the ISDA are illustrative of the global reach of the market. ${ }^{376}$ Primary members of the ISDA represent the largest and most sophisticated financial institutions that actively participate in the ISDA and typically would either be a swap dealer or would generally be active on both sides of a market.

Although there are twenty-two US members and ninety-three E.U. primary members of the ISDA, there are a number of primary members organized in a jurisdiction other than the United States or the European Union. This diver-

374 Bank for InT'L Settlements, supra note 17, at app. A, at 141.

375 Will Acworth, FCM Leaders Discuss Industry Outlook, FuTURES INDUSTRY, June 2010, at 19, 19-21 (discussion of effect of uncertainty on customers), available at http://www .futuresindustry.org/files/css/magazineArticles/article-1462.pdf.

376 Primary members are large financial institutions that typically either act as a dealer or are very active traders in the market. For a list of primary members, see ISDA Members: Primary, ISDA, http://www2.isda.org/membership/members-list/primary/ (last visited Feb. 25, 2014). 
sity includes six in Australia, three in Brazil, seven in Canada, eight in China, five in India, five in Israel, twelve in Japan, one in Kazakhstan, four in Malaysia, one in Namibia, one in Nigeria, one in Pakistan, four in Russia, two in Singapore, ten in South Africa, nine in South Korea, nine in Switzerland, two in Taiwan, and one in the United Arab Emirates. ${ }^{377}$ Without taking into account the US and E.U. countries, there are primary members in twenty-one countries (with a total of ninety-two members). ${ }^{378}$ Of those twenty-one countries, eleven are not in the G20 (with a total of twenty-eight non-G20 primary members). ${ }^{379}$ All of these twenty-one countries (in addition to the E.U. countries) will need to adopt OTC derivative regulations comparable with the United States if regulatory arbitrage is to be avoided.

One tool that the CFTC has to combat the formation of such dealers in an unregulated jurisdiction is Section 715 of Dodd-Frank. The Section provides the CFTC with teeth in punishing foreign swap markets if "the regulation of swaps . . . markets in a foreign country undermines the stability of the United States financial system . ..."380 In such a situation, the CFTC "may prohibit an entity domiciled in the foreign country from participating in the United States in any swap ...." 381 The net effect is that if the CFTC believes that a foreign market has not enacted sufficient reforms or rules such that it creates instability in the United States, it can prohibit the participants from such markets from trading in the United States. This may discourage a jurisdiction from permitting the formation of such entities.

\section{Building Non-US/G20 Dealers}

One concern is that, even if a less-regulated jurisdiction can be identified as a possible trading jurisdiction, would a swap dealer in such a jurisdiction have sufficient capital or expertise to be a credible alternative to those global swap dealers organized in G20 countries (and thus subject to higher regulation)? Historically, the industry has already worked through an analogous situation when it created credit-worthy entities to deal with a perceived worsening of creditworthiness among the major dealers themselves in order to continue trading with risk-averse customers.

In an effort to generate additional business in the 1990s under these conditions, several dealers formed what is commonly referred to as AAA trading entities, going by such names as Swapco, Lehman Brothers Derivative Products, and Goldman Sachs Mitsui Marine. ${ }^{382}$ These entities were all highly rated

377 Id. The identification of origin of organization of the 200 ISDA primary members is admittedly imprecise and difficult to determine, with it being probable that there are errors in these determinations.

378 See id. The list of banks was categorized by the author.

379 See id.

380 Dodd-Frank Act, Pub. L. No. 111-203, § 715, 124 Stat. 1647 (codified as amended at 15 U.S.C. § 8304 (2012)).

381 Id.

382 Tracy Corrigan, Salomon Sets Up Triple-A Rated Derivatives Unit, Fin. TimEs, Feb. 9, 1993, at 19 ("[M] any potential clients are unwilling to deal with institutions rated less than double A."); see also Rosemary Bennett, Triple-A Vehicles Provoke Suspicion Among Users, Euromoney, Mar. 1994, at 58, 58 ("The shrinking universe of triple-A banks cannot satisfy demand for the top credit rating among derivatives' users.”); William B. Crawford, 
due to their amount of capital, structure, and their being typically bankruptcy remote. ${ }^{383}$ It is possible that a group of investors could create and capitalize a "AAA" rated swap dealer entity in a less-regulated jurisdiction in order to capture business with entities trying to avoid the new OTC derivative reforms.

In our world of modern technology and mobility, it should be straightforward to create such a swap dealer. As trading floors proliferate across the globe, it should be possible to recruit experienced and savvy personnel to trade, manage, and run a trading floor and derivative book. Journeymen derivative salesmen with rolodexes full of anxious customers could be recruited to create a critical mass to make such a book of business possible. Although there would clearly be regulatory and practical barriers to implementing such a strategy, there may be sufficient profit potential in continuing to trade outside of the proposed regulatory reforms that such a possibility could become a reality.

\section{The Transparency and Success Paradox}

The very success of the Dodd-Frank and G20 reforms may actually facilitate regulatory arbitrage. A key goal of the OTC derivatives is to increase transparency in the market, particularly for pricing. As more OTC derivatives are exchange traded, public pricing becomes readily and easily available, potentially available to those that do not avail themselves of US markets and that instead trade in less-liquid and less-regulated jurisdictions.

A key disadvantage to the current market (and arguably a continued disadvantage to less-regulated jurisdictions) is limited pricing transparency. ${ }^{384}$ This lack of transparency in the less-regulated jurisdictions should actually then encourage a party to trade in the United States and G20 as the markets become more transparent. The paradox, however, is that because this pricing transparency in the US and G20 markets is public, it will make pricing in other lessregulated markets transparent as well.

A party not subject to Dodd-Frank or G20 rules will immediately be able to determine if the pricing quoted to it in the less-regulated jurisdiction is fair because the pricing in the regulated markets will become more transparent. ${ }^{385}$ Paradoxically, as pricing becomes more transparent in US and G20 markets, parties trading in less-regulated jurisdictions will become more confident as they are able to compare their pricing (in bilateral trading) against publicly available information in higher-regulated jurisdictions.

\section{The Credit Worthiness Conundrum}

The recent spate of increased clearing of OTC derivatives highlights a peculiar problem for conforming jurisdictions that require OTC derivatives to be cleared through clearinghouses. Making these G20 jurisdictions safer may in some limited ways make them riskier.

\footnotetext{
Jr., In Swaption World, It Has to Be AAA, ChI. Trib., Feb. 21, 1994, at C1; Michael Peltz, Wall Street's Triple-A for Effort, Institutional Investor, May 1993, at 89, 89 (participants are demanding collateral upon downgrade of their counterparty).

383 Bennett, supra note 382, at 58, 63.

384 See supra Part II.D (discussion of the value of transparency).

385 See supra Part II.D.
} 
As swap dealers such as Morgan Stanley faced credit rating downgrades, concerned counterparties attempted to move much of their trading with these dealers to clearinghouses in order to minimize their credit risk: " 'I would say that the majority of customer clearing has not been because of Dodd-Frank but because of counterparty credit concerns,' said one person with knowledge of the move but who was not authorised to speak on behalf of participants." ${ }^{886}$ In other words, a key motivator for moving to an OTC derivative cleared environment was to shift the credit risk away from the bilateral trading relationship and into a safer clearinghouse. Further downgrading of the dealer community would arguably accelerate that trend. ${ }^{387}$ Counterparties would thus lay off their own credit risk by trading with downgraded dealers by only clearing such trades through clearinghouses.

Such an analysis suggests a strong motivation for a non-US person (not registered with CFTC) to trade with US persons in a clearinghouse environment when trading with less credit worthy dealers. The non-US person would then trade with more credit-worthy dealers in less or non-regulated jurisdictions not subject to the same Dodd-Frank/G20 regulation. The end result, oddly enough, would introduce risk in to the regulated jurisdictions and move trades with more credit worthy entities into less-regulated jurisdictions.

\section{A Different form of Regulatory Arbitrage: The "Futurization" of the Swaps Market}

In an extraordinary transformation, a different form of regulatory arbitrage has sprung up to deal with "jurisdictional" regulatory arbitrage issues caused by Dodd-Frank. As opposed to the regulatory arbitrage discussed in this paper where parties move to different jurisdictions to do the same transactions, parties are now either recasting their OTC derivatives as futures or simply replacing their hedging transactions with exchange-traded futures instead of OTC derivatives. ${ }^{388}$ This type of regulatory arbitrage "exploits the gap between the economic substance of a transaction and its legal or regulatory treatment, taking advantage of the legal system's intrinsically limited ability to attach formal labels that track the economics of transactions with sufficient precision."389

386 Demos \& Alloway, supra note 198.

387 " A downdraft in credit ratings for the entire dealer community could potentially accelerate the move towards greater adoption of central clearing ahead of mandatory clearing requirements,' the analysts wrote in a note this week." Id.

388 Will Acworth, Futurization: Dodd-Frank Drives Swaps-to-Futures Migration, FuTURES INDUSTRY, Jan. 2013, at 33, 33, available at http://www.futuresindustry.org/futures-industry .asp?iss=209\&a=1531; CFTC Staff to Host Public Roundtable to Discuss the "Futurization of Swaps”, U.S. Commodity Futures Trading Comm'n, http://www.cftc.gov/PressRoom/ Events/opaevent_cftcstaff013113 (last updated Feb. 4, 2013) (select "Roundtable Video"); Swap Futurization Could Spell Imperfect Hedging, Euromoney, http://www.euromoney .com/Article/3187664/Swap-futurization-could-spell-imperfect-hedging.html (last visited Feb. 25, 2014).

389 Victor Fleischer, Regulatory Arbitrage, 89 TEx. L. REv. 227, 229 (2010); see also Michael S. Knoll, The Ancient Roots of Modern Financial Innovation: The Early History of Regulatory Arbitrage, 87 OR. L. REv. 93, 94 (2008); Frank Partnoy, Financial Derivatives and the Costs of Regulatory Arbitrage, 22 J. CoRP. L. 211, 227 (1997). 
As participants deal with the uncertainty and costs of trading OTC derivatives under Dodd-Frank, this appears to be driving them away from the OTC derivatives market and into the exchange traded futures market. Commentators have noted that a "big concern for the swaps industry is that final Sef rules may be too strict and impose higher costs on users of OTC products, only encouraging greater use of futures." 390

In an effort to avoid being treated as a swaps dealer under Dodd-Frank or to avoid other concerns with Dodd-Frank, parties are turning to the exchangetraded futures market. CFTC Commissioner Scott O'Malia noted the following:

This may have come as a surprise to some, but not to those who trade in these markets. Given the inconsistency in the Commission's interpretation of its own rules, the lack of regulatory certainty and the increased cost of compliance with the Commission swaps regulations, including the complicated and controversial swap dealer definition rules, swap customers have turned to futures markets for regulatory certainty. $^{391}$

The calculus is not whether futures are better or a safer alternative to OTC derivatives, but rather whether they avoid Dodd Frank.

Already there is evidence in the OTC energy derivatives market that participants are trading in different ways through the futures market to avoid Dodd-Frank. For example, "[1] ast month, IntercontintentalExchange (ICE) converted its cleared energy swaps to futures, partly to help companies such as commodities trading houses to avoid the cost of designation as swap dealers."392

The CME has also been aggressive in helping participants avoid being characterized as swap dealers: "CME Group, the largest US derivatives exchange, started allowing more OTC swaps to be executed as so-called 'block' futures trades, which 'will not be subject to swaps regulation,' it said in a notice." $" 393$

In spite of whatever arguments parties may make that this may not necessarily be a bad thing, market participants note that the key driver is the regulatory burdens being placed on OTC derivatives: “ 'Certainly I don't think we'd be here talking about swap futures if it weren't for Dodd-Frank regulation,' said Michael Riddle, chief operating officer at Eris Exchange. 'That's kind of the key driver here.' "394 Another market participant has noted the same rationale:

390 Michael Mackenzie \& Gregory Meyer, US Swaps Shake-up Set to Boost Exchanges, Fin. Times (Nov. 1, 2012, 5:32 PM), http://www.ft.com/cms/s/0/cadeef74-2377-11e2-a46b -00144feabdc0.html\#axzz2epX3MxAp.

391 CFTC's O'Malia Says Cross-Border Approach Suffers from Flaws, AutomatedTRADER (Sept. 27, 2012), http://www.automatedtrader.net/headlines/137233/cftcs-omalia -says-cross_border-approach-suffers-from-flaws.

392 Mackenzie \& Meyer, supra note 390; see also John McCrank, UPDATE 2-ICE's Swaps Switch Moved Up to October from January, Reuters (Sept. 5, 2012, 1:06 AM), http:// in.reuters.com/article/2012/09/04/intercontinentalexchange-swaps-idINL4E8K43SX201209 04; Birth of a Market? As Dodd-Frank Takes Hold, Swaps Futures Are In the Limelight, AutomatedTrader (Oct. 31, 2012), http://www.automatedtrader.net/headlines/141712 /birth-of-a-market-as-dodd_frank-takes-hold—swaps-futures-are-in—the-limelight [hereinafter Birth of a Market?].

393 Mackenzie and Meyer, supra note 390.

394 Birth of a Market?, supra note 392. 
"I think that's going to be either an accelerator for swap futures or it may slow down, depending on which way it goes," Vedbrat [managing director and co-head of electronic trading and market structure at BlackRock] said. "You know, if we see something very prescriptive like we always have to quote to five dealers I think that the swaps futures market will take off much faster." 395

A key tradeoff in this futurization of swaps is that parties lose the advantages of customized or bespoke trades; the ability to tailor a hedge to a particular risk: "This migration raises the prospect that once interest rates or energy prices change rapidly, many investors may be caught out by relying on a future rather than a customised swap that better matches their portfolio's risk." 396 In some ways, the inability to customize their hedge may actually increase the risk of a transaction, even if it is cleared.

It is also unclear if regulators have thought through whether any surge in trading "futures" on swaps to replace OTC derivatives may pose any unintended consequences. One issue may be concerned with volumes, increased concentrations with clearinghouses, or significantly greater cash flows being run through clearinghouses.

\section{RECOMMENDATIONS}

As explained above, the US approach to containing regulatory arbitrage is principally first to harmonize US regulation with competing jurisdictions, and, second, through the use of brute force of extraterritorial jurisdiction. The recommendations below attempt to provide suggestions for ways to minimize regulatory arbitrage and maximize the cooperation of competing jurisdictions with the United States.

\section{A. Balancing Safety Against Regulatory Arbitrage}

US policymakers and regulators are aware that regulatory arbitrage could inadvertently trigger financial instability in the United States if swap activity moves to unregulated jurisdictions to escape the costs of Dodd-Frank regulation. Although much of the regulatory arbitrage may be to G20 jurisdictions where regulation is comparable, it may move to darker unregulated jurisdictions as well. The United States may want to consider accepting a lower level of regulation in order to minimize regulatory arbitrage.

There would appear to be a tradeoff between the level of regulation and the likelihood of regulatory arbitrage. In other words, if one could measure the level of regulation on a continuum, first, at what point of increasing regulation do non-US persons in the US market move to other less- (or non-) regulated jurisdictions? And, second, at what point of increasing regulation do US persons attempt to structure their swap activities away from the United States? Arguably, if the United States were to lessen the US level of regulation of OTC derivative markets, that should decrease the amount of regulatory arbitrage, minimizing the possibility that the risks will simply be transferred to unregulated jurisdictions.

395 Id.

396 Mackenzie \& Meyer, supra note 390. 
The "Regulatory Arbitrage Frontier" Figure below (see Figure 1) attempts to illustrate the relationship between increasing regulation (with a corresponding increase in burdens and costs) and increased regulatory arbitrage (i.e., parties shifting their trading to less-regulated markets). The Y-axis in the table provides a measurement between zero regulation and infinite regulation (i.e., a total ban in a jurisdiction on OTC derivative trading). For purposes of this discussion, assume that US markets are regulated at a higher level than G20 jurisdictions. The $\mathrm{X}$-axis in the table provides a measurement of increasing regulatory arbitrage (i.e., the amount of swap activity that will occur outside of a jurisdiction because of increasing regulation).

Figure 1 further assumes that functioning OTC derivative markets will be developed outside of G20 jurisdictions, assuming that the burdens of trading at a particular level of regulation exceeds any benefit from trading in the regulated market.

Figure 1 - the Regulatory Arbitrage Frontier

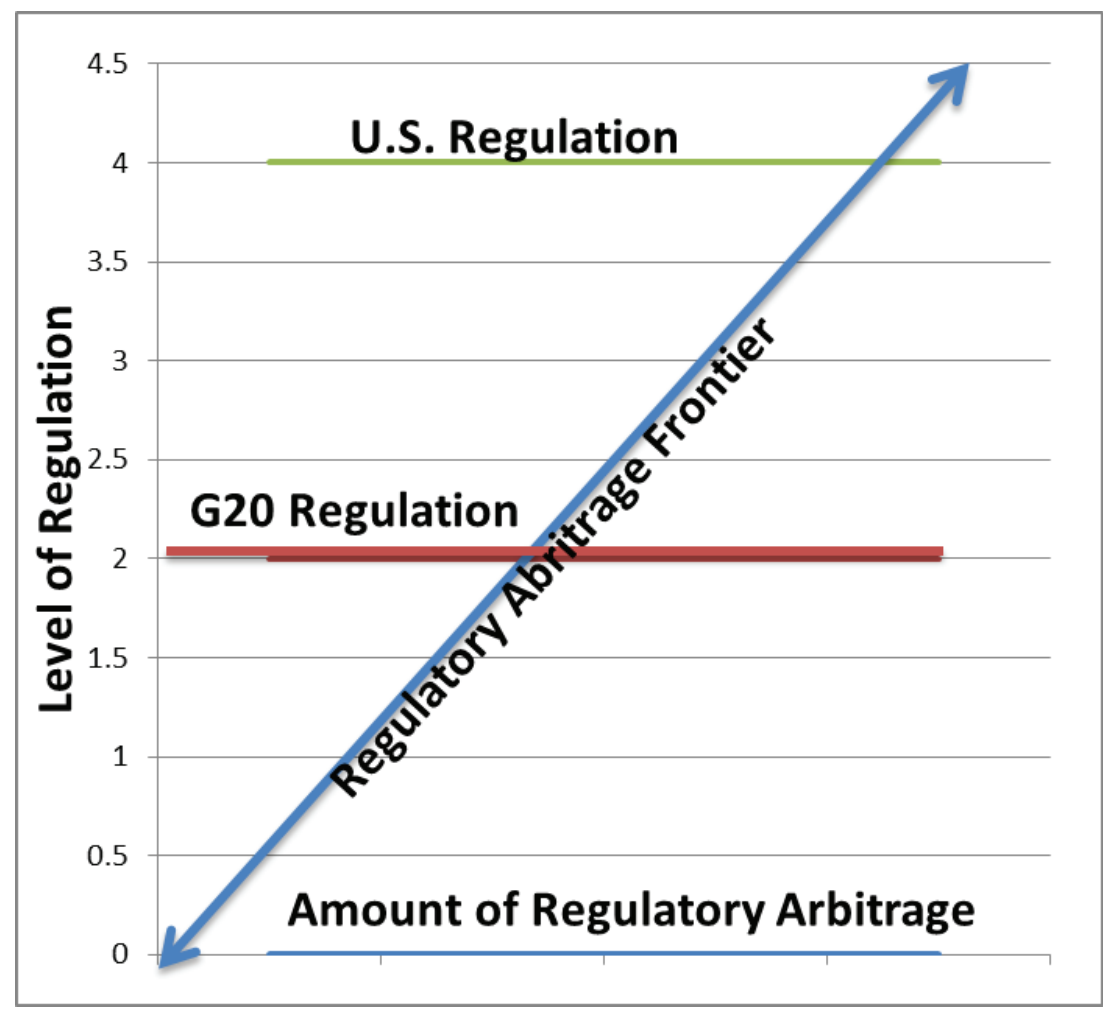

For example, at the " 0,0 " coordinate, there is no regulation. Accordingly, if there was zero regulation, there would be no motivation for regulatory arbitrage, and therefore regulatory arbitrage would be zero. As regulation increases, it is assumed that parties would respond by moving swap trading activity outside of regulated markets (if legal, practical, or possible). Conversely, if increasing regulation made swap activity trading less beneficial, eventually all 
swap trading would be done outside of US regulation. This relationship is illustrated by the diagonal line labeled the "Regulatory Arbitrage Frontier."

The "Regulatory Arbitrage Frontier" first illustrates that regulatory arbitrage will begin immediately (albeit at a de minimis level). Policymakers should be aware that anytime the burdens of regulation at a particular point exceed the benefits of the trade at the particular point, regulatory arbitrage will occur unless a jurisdiction can exercise extraterritorial jurisdiction over that trading activity.

Second, because we are assuming that US regulation is greater than G20 Regulation, for purposes of this figure, the "Regulatory Arbitrage Frontier" demonstrates that once the United States increases its regulation above the G20 level of regulation, regulatory arbitrage will cause trading activity to move from the United States to a G20 jurisdiction or to a less-regulated jurisdiction. The only way for the Unites States to decrease that regulatory arbitrage is either through extraterritorial enforcement by the CFTC or by decreasing the level of US regulation until the US regulation is equal to the G20 Regulation.

Any gap along the "Regulatory Arbitrage Frontier" will result in regulatory arbitrage occurring between the higher regulated jurisdiction and the lower regulated jurisdiction. The only solution for the United States to decrease the amount of regulatory arbitrage that is leaking into G20 jurisdictions is to close the gap between the two levels of regulation.

As the United States struggles to deal with potential regulatory arbitrage, the question becomes: at what point does increasing the level of US regulation lead to an unacceptable amount of regulatory arbitrage? The United States appears to believe that it has already determined the appropriate amount of regulation and is trying to deal with potential regulatory arbitrage through the force of extraterritorial regulation. However, if either non-US or US participants are able, through the help of clever investment bankers, to move significant swap activity out of the United States or G20 jurisdictions, the end result may be significant swap activity in unregulated markets that may present possible systemic financial risks to the United States in the future.

There is also the possibility, however, that the United States will not have to engage in this calculus, betting that the US race to the top will create a trading environment so robust, safe, transparent, efficient, and profitable that regulatory arbitrage will not rear its ugly head. Instead of fleeing US markets, participants will flock to the United States to trade. ${ }^{397}$

\section{B. Balancing Appropriate Regulation with Inter-Jurisdictional Harmony}

As the United States pursues its rule-making activity to implement DoddFrank, it is consulting and meeting with the G20 and other jurisdictions to promulgate US rules and regulations that are comparable or "harmonious" with these competing jurisdictions. To avoid regulatory arbitrage between the various jurisdictions, however, either the United States or the competing jurisdictions must be willing to compromise in order to eliminate the differences in regulation.

397 See supra text accompanying notes $150-51$. 
Foreign regulators have lectured the United States that there is more to meeting the G20 commitments than simply enacting legislation:

But as has been continuously stressed by G20 leaders since 2009, domestic legislation alone does not fulfil the political aim that was agreed in Pittsburgh and reaffirmed in Toronto in 2010. Regulation across the G20 needs to be carefully implemented in a harmonised way that does not risk fragmenting vital global financial markets. ${ }^{398}$

They continue by urging the United States "to take the time to ensure that US rulemaking works not just domestically but also globally." 399 Asian regulators have also urged restraint in rushing to implement regulations: "Consideration should also be given to deferring the application of the relevant requirements until there is international consensus on how such cross-border transactions should be regulated." 400

This relationship between the appropriate level of regulation between competing jurisdictions can be illustrated by the "Compromise Frontier" in Figure 2. Figure 2 assumes that the US regulation will be at a higher level than G20 regulation. Figure 2 illustrates how either the level of US regulation must be lowered to the level of G20 regulation or the level of G20 regulation must increase if regulatory arbitrage is going to be minimized. The Y-axis is the Level of Regulation and the $\mathrm{X}$-axis is intended to show how the parties will need to compromise in order to close the gap or differences between US regulation and G20 regulation. As long as the US and G20 jurisdictions are unwilling to compromise over the rules, there will exist a difference in regulation which could result in regulatory arbitrage as participants attempt to move away from the United States to a jurisdiction with lower regulation. The diagonal line between the two levels of regulation is the "Compromise Frontier" and represents how either the United States or G20 (or both) must change their level of regulation if the gap that will trigger regulatory arbitrage can be avoided. As parties move along the "Compromise Frontier," eventually the parties will reach a point of compromise about the amount of regulation that is appropriate.

\section{More Liberal Approach to Substituted Compliance}

There is evidence that foreign governments are becoming much less tolerant of the United States' continued position that foreign regulation must be highly comparable to that of the United States. As explained above, the Final Guidance suggests that the CFTC, on a unilateral basis, will review the individual regulatory requirements of foreign jurisdiction to determine if the regulations are comparable. Although the Final Regulation provides that the review for comparability will "in most cases, involve consultation with the regulators in each jurisdiction for which a substituted compliance application has been submitted," there is ultimately no requirement on the CFTC to respect or accept a regulator's position on an issue..$^{401}$

398 Osborne et al., supra note 201.

399 Id.

400 Foreign Regulators' Letter, supra note 133, at 3.

401 Final Guidance, 78 Fed. Reg. 45,292, 45,344 (July 26, 2013) (to be codified at 17 C.F.R. pt. 1). 
Figure 2 - The Compromise Frontier

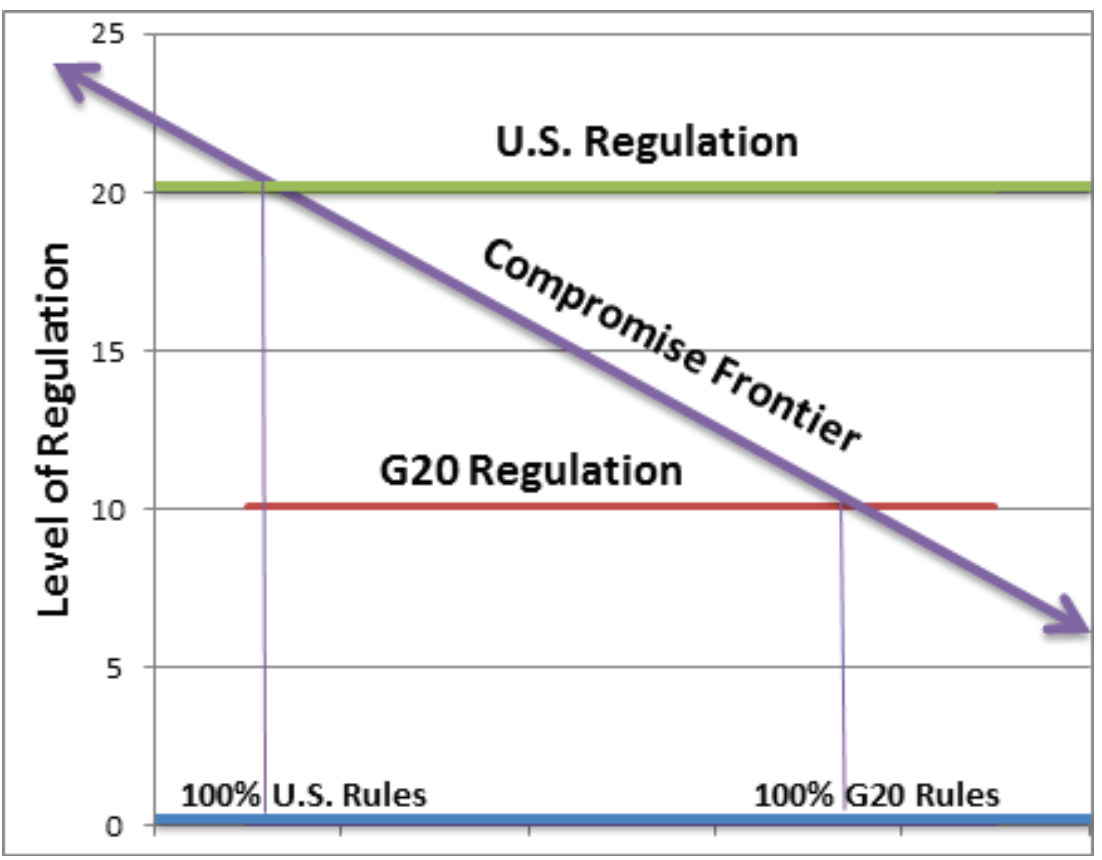

In an extraordinary public letter to Chairman Gensler of the CFTC dated October 12, 2012, from the Chancellor of the Exchequer in the U.K., the Commissioner for Internal Markets at the European Commission, the Minister of State for Financial Services of Japan and the Minister of Finance for the Government of France, the regulators expressed their concerns:

We of course recognise and understand the need for US and other regulators to satisfy themselves on the adequacy of regulation in other jurisdictions. But we would urge you before finalising any rules, or enforcing any deadlines, to take the time to ensure that US rulemaking works not just domestically but also globally. We should collectively adopt cross border rules consistent with the principle that equivalence or substituted compliance with respect to partner jurisdictions, and consequential reliance on the regulation and supervision within those jurisdictions, should be used as far as possible to avoid fragmentation of global markets. Specifically, this principle needs to be enshrined in CFTC cross border rules, so that all US persons wherever they are located can transact with non-US entities using a proportionate substituted compliance regime. ${ }^{402}$

Commenters have further noted that foreign regulators in general are becoming increasingly impatient with the CFTC's insistence on determining comparability to CFTC rules. ${ }^{403}$

402 Osborne et al., supra note 201.

403

This is an understated letter to the CFTC saying that the CFTC's cross-border rules do not work, and that they should not be adopted until harmonized with the rules of non-U.S. regulators and that the CFTC's final rules must recognize that non-U.S. firms should be deemed to have complied with any U.S. rules by virtue of compliance with home-country rules. In earlier letters, the non-U.S. regulators had sounded a harsher tone, albeit with the same message: the CFTC needs to back off on regulation of non-U.S. swaps dealers. 
Such direct public lobbying by foreign regulators may hopefully temper the CFTC's enthusiasm for enforcing its own standards through extraterritorial jurisdiction. The CFTC will need to recognize sooner, rather than later, that other G20 jurisdictions are not going to tolerate the United States holding foreign G20 banks to higher standards of regulatory form than these jurisdictions recognize as necessary.

\section{Reaching Out to Non-G20 Jurisdictions}

The most serious long-term concern of regulatory arbitrage is that swap dealers will spring up in non-G20 jurisdictions that have not enacted OTC derivative reforms. For such jurisdictions, providing a forum for unregulated OTC derivative trading will be similar to the function that tax havens provide offshore companies with a tax-free business environment. ${ }^{404}$ The United States and G20 countries should aggressively court these jurisdictions and encourage them to enact rules and regulations that would meet the US standard of "substitute compliance."

The main question of such a scenario is where such trading would arise. Singapore, for example, would certainly have the sophisticated financial environment and capabilities to provide such a non-US/G20 trading environment. Fortunately, Singapore does not appear to be even remotely interested in becoming a rogue state that offers non-US persons opportunity to trade free of OTC derivative reforms. In fact, Singapore is well ahead of most jurisdictions in offering OTC derivative regulatory reforms. ${ }^{405}$ Singapore is also well ahead of most jurisdictions in attempting to provide a way to clear OTC derivatives over the past decade, well before G20 countries were even considering such a requirement. ${ }^{406}$ Ironically, however, a large Singaporean swap dealer has recently announced that it will not trade in the United States due to the high Dodd-Frank regulatory costs. ${ }^{407}$

As explained above, however, it is not necessary to find a sophisticated non-G20 jurisdiction such as Singapore to host unregulated OTC derivative trading. Because the necessary capital, personnel, and technology can easily be imported into such a jurisdiction, it would be relatively easy for a non-US person, interested primarily in avoiding US and G20 regulation, to set up shop and

Steven Lofchie, Joint Cautionary Letter from the EU, France, Japan and the UK to the CFTC on U.S. Cross-Border Swaps Regulation, Center Fin. Stability (Oct. 19, 2012), http://centerforfinancialstability.org/wp/?p=594.

404 See supra Part II.

405 MAS Reviews Regulation of the Derivatives Market in Singapore, Monetary AuthorITY SING. (Feb. 13, 2012), http://www.mas.gov.sg/en/News-and-Publications/Press-Releases /2012/MAS-Reviews-Derivatives-Market.aspx; see also Monetary Auth. of Sing., Consultation Paper on Proposed Regulation of OTC Derivatives 1 (2012), available at http://www.mas.gov.sg/ /media/resource/publications/consult_papers/2012/13\%20February $\% 202012 \% 20$ Proposed $\% 20$ Regulation\%20of\%20OTC\%20Derivatives.pdf.

406 The Singapore Stock Exchange provides derivatives clearing for OTC interest rate swaps for example. See Derivatives Clearing, Sing. Exchange, http://www.sgx.com/wps /portal/sgxweb/home/clearing/derivatives (last visited Feb. 25, 2014).

407 See Neeraj Batra, Tabb Grp., Who Are the Swap Dealers? 2 (2013), available at http://www.cmegroup.com/education/files/tabb-dealers-2013-04-19.pdf; Vaughan \& Burne, supra note 203. 
provide a means to trade OTC derivatives outside of the G20. To arrest such activities, the US and G20 jurisdictions need to work with non-G20 jurisdictions to enact similar derivative reforms.

\section{E. Critique of CFTC Final Guidance}

As mentioned above, the guidance issued by the CFTC has provided an avalanche of comment letters, suggesting a variety of substantive and more technical changes that deal with how the CFTC should exercise its extraterritorial jurisdiction. A review of the guidance ${ }^{408}$ and the numerous comments critiquing it, suggest a number of key changes that will help reduce regulatory arbitrage and eliminate much of the uncertainty and confusion in the Proposed Interpretive Guidance. The comments below only address a few of the more salient critiques provided and do not discuss the numerous more technical changes that market participants believe should be made as well.

\section{Permit "Substituted Compliance" for Non-US Persons in all Situations}

One key concern with the concept of substituted compliance is that it does not deal with the most common situation of a US swap dealer entering into a swap with a non-US person with respect to Transaction-Level Requirements (except with respect to the foreign branch of a US Bank that is a swap dealer or MSP). ${ }^{409}$ The final guidance generally does not permit substituted compliance to apply in this particular situation, regardless if such non-US person is otherwise subject to comparable regulation in another jurisdiction. In other words, there will always be the possibility of duplicative and inconsistent non-US regulation applied to the non-US person in trading with a US person. ${ }^{410}$

If the United States is concerned about the financial stability of the nonUS person, it does not make any sense to allow "substituted compliance" in some situations and not in others. For example, why is it acceptable or safe to allow a non-US person to use substituted compliance with a non-US person but not with a US person. If the non-US person, when it complies with substituted compliance with a non-US person, is not a risk to the United States, why would it put the United States at risk to trade with a US person using substituted

408 See supra text accompanying notes 259-86.

409 Alt. Inv. Mgmt. Ass'n Letter, supra note 357, at 13.

410 Various parties have commented about the necessity to avoid duplicative and conflicting regulations between jurisdictions. See Letter from Kenneth E. Bentsen, Jr., Exec. Vice President, Sec. Indus. and Fin. Mkts. Ass'n, to David A. Stawick, Sec'y, Commodity Futures Trading Comm'n 2 (Aug. 27, 2012), available at http://comments.cftc.gov/PublicComments/vIEWcOMMENT.ASPX?ID=58652\&SearchText=SIFMA; Letter from Patrick Raaflaub, Chief Exec.Officer, Swiss Fin. Mkt. Supervisory Auth., and Mark Branson, Head of Banks Div., Swiss Fin. Mkt. Supervisory Auth., to Gary Gensler, Chairman, Commodity Futures Trading Comm'n 1 (July 5, 2012), available at http://comments.cftc.gov/PublicCom ments/ViewComment.aspx?id=58317\&SearchText=SWISS\%20FINANCIAL\%20MARKET \%20SUPERVISORY; Letter from Masamichi Kono, Vice Comm'r for Int'l Affairs, Fin. Servs. Agency, Gov't of Japan, and Hideo Hayakawa, Exec. Dir., Bank of Japan, to Gary Gensler, Chairman, Commodity Futures Trading Comm'n 1-2 (Aug. 13, 2012), available at http://comments.cftc.gov/PublicComments/ViewComment.aspx?id=58383\&SearchText= BANK\%20OF\%20JAPAN. 
compliance. Provided that the rules and regulations are comparable, substituted compliance should be permitted for a non-US person in all circumstances, regardless as to whether a US person is involved.

\section{Making Determinations on an Individual Requirement Basis Rather than the Foreign Regulatory Regime as a Whole}

One concern in numerous comment letters was that the Proposed Interpretive Guidance provides that a determination of whether a jurisdiction's rules meet the "substituted compliance" test should be done on an individual requirement basis. ${ }^{411}$ In an important compromise, the CFTC has agreed to an "outcomes-based approach", as discussed above, but this determination will still be done by individually analyzing thirteen different categories of regulatory obligations. ${ }^{412}$ In other words, although the regulations do not need to be identical and the CFTC will look to whether such regulation achieves the same goals as the CFTC regulations, there is no authority for the CFTC to consider the foreign regulatory structure as a whole.

For example, if done on an individual requirement basis, the CFTC must question whether a competing jurisdiction's mandatory exchange-trading requirement is comparable with that of the United States. As long as the nonUS person's jurisdiction has a mandatory exchange-trading requirement that is comparable, this becomes a straightforward determination. It becomes more complicated, however, if a jurisdiction has made a decision that mandatory exchange trading is not required in that particular jurisdiction.

A straightforward reading of the Final Guidance would suggest that the non-US person, if it were a registered swap dealer under Dodd-Frank, would still be required to comply with the mandatory exchange-trading rule, even though its home jurisdiction finds it unnecessary or problematic in that jurisdiction. In other words, the CFTC is only willing to grant comity on a requirement-by-requirement basis to a foreign jurisdiction, as opposed to recognizing the safety and soundness of a foreign jurisdiction's regulatory regime, considered as a whole.

This is in contrast to a test (not permitted under the Proposed Interpretive Guidance) in which the CFTC were to make a determination as to whether the entire jurisdiction's regulatory structure or requirements, considered as a whole, is comparable to Dodd-Frank. For example, if a jurisdiction's requirements, considered as a whole, were comparable to Dodd-Frank, a non-US swap dealer would not be required to comply with individual Dodd-Frank requirements (such as mandatory exchange trading) that were not found in that jurisdiction's rules.

As explained above, jurisdictions have many rationales for agreeing, or not agreeing, with another jurisdiction's regulations, ${ }^{413}$ refusing to adopt those

411 See Letter from Walt Lukken, President, Chief Exec. Officer, Futures Indus. Ass'n, to David A. Stawick, Sec'y, Commodity Futures Trading Comm'n 5-6 (Aug. 27, 2012), available at http://comments.cftc.gov/PublicComments/ViewComment.aspx?id=58679\&Search Text=FUTURES\%20INDUSTRY\%20ASSOCIATION.

412 Final Guidance, 78 Fed. Reg. 45,292, 45,344 (July 26, 2013) (to be codified at 17 C.F.R. pt. 1).

413 See supra text accompanying notes $411-12$. 
that it finds counterproductive or even injurious to that particular jurisdiction. A thoughtful set of regulatory reforms enacted by one jurisdiction may be just as safe and effective at eliminating risks as another jurisdiction's, albeit that the individual components of the regulation may differ. If the CFTC considers the absence of one particular reform to be so critical to the safety and soundness of a jurisdiction, it can find that the jurisdiction's entire regulations, taken as whole, are not comparable to the United States and need not permit substituted compliance. Otherwise, insisting on comparable regulation with every element of Dodd-Frank regulation, even though such a jurisdiction provides a safe regulatory environment, would seem unnecessary and perhaps contemptuous or disdainful of another jurisdiction's regulatory decision-making process.

\section{Divergent Versus Comparable Rules and Regulations}

A sister concern of the above issue is that, when comparing individual regulatory requirements, the CFTC rules only provide for comity and substituted compliance when there is a comparable rule. ${ }^{414}$ The rules do not provide for how to deal with situations in which other jurisdictions have made decisions not to impose a particular requirement. For example, if a competing jurisdiction did not have a mandatory exchange-trading requirement, then substituted compliance would not be possible and the non-US person would be required to conform to the Dodd-Frank rule. In other words, there is no mechanism in the Proposed Interpretive Guidance to allow the CFTC to exempt compliance from a particular rule because a competing jurisdiction does not provide such a requirement.

The CFTC should consider providing guidance as to when such an exemption from a requirement for a non-US person, based on the absence of such a rule in a competing jurisdiction, is permissible. Such guidance might consist of requiring the CFTC to consider why that particular requirement is absent or if there are compensating requirements that make up for its absence.

\section{CONCLuSion}

The effort to reform the OTC derivative markets by the United States and G20 jurisdictions may constitute one of the most aggressive regulatory reform efforts ever attempted for a global capital market. These new rules and regulations will cause industry participants to completely redesign their business practices and processes, all done in an effort to make US markets safe from systemic failures caused by OTC derivative losses. This regulatory effort, as evidenced by the thousands of pages of new statues and regulations promulgated by Congress and the CFTC to carry out Dodd-Frank, will serve as a case study for the "do's and don'ts" of regulatory reforms for future decades.

The regulatory effort is complicated by the size, global reach, and complexity of the OTC derivative market, and has resulted in great uncertainty with respect to how OTC derivative markets will operate and appear in the coming

414 Final Guidance, 78 Fed. Reg. at 45,344 ("Where no comparability determination can be made, the non-U.S. swap dealer . . . may be required to comply with the applicable Entity- or Transactional-Level requirements ...."). 
years. As capital flows almost seamlessly around the world, policymakers and regulators are concerned that the different degrees of regulation that may emerge from this global regulatory reform effort may result in regulatory arbitrage as participants may attempt to trade in less-regulated markets. In contrast, US regulators hope that the reforms will result in more stable, transparent, and efficient markets, enticing existing and new participants to continue trading in the US. The uncertainty, costs, and heavy regulation that has come out of these reform efforts, however, may prove to be a strong motivator for parties to find the most regulatory friendly trading environment.

The United States and the other G20 countries have tried to deal with the risk of regulatory arbitrage in several different ways. The United States appears convinced that making global OTC derivative dealers comply with either Dodd-Frank or comparable G20 regulations as a ticket to trading in the US market will prevent OTC derivative dealers from trading in unregulated jurisdictions. Technocrats from the various G20 countries are also working tirelessly to harmonize the different regulatory regimes in such a way that they are each consistent and comparable with each other, again reducing the motivation for participants to search out lightly regulated environments.

The CFTC has recently issued final proposed guidance describing how it will impose Dodd-Frank requirements on the non-US derivative activities for both US and non-US persons. Although complicated and long, this guidance at least serves as a starting point for negotiations with other jurisdictions over the extraterritorial reach of the CFTC and Dodd-Frank. The concern, of course, is that clever investment bankers will eagerly develop new programs, structures, and entities to exploit the inconsistences that will inevitably develop as these OTC derivative reforms are put into law in competing jurisdictions.

Reforming global capital markets is never simple, especially one as nimble and fast moving as OTC derivatives. Already beginning, it is inevitable that regulatory arbitrage will occur as firms attempt to avoid Dodd-Frank regulation and escape to less-regulated jurisdictions. As the United States attempts to limit regulatory arbitrage opportunities, it must at a minimum close the regulatory gap between the United States and the other G20 jurisdictions. Although the CFTC has been given extraterritorial jurisdiction powers by the US Congress, it must judiciously use them to avoid infuriating foreign jurisdictions and driving OTC derivative trading even further into unregulated environments. 